\title{
BLISTERING PHENOMENA IN THE ENAMELING OF CAST IRON
}

\author{
By A. I. Krynitsky and W. N. Harrison
}

\begin{abstract}
In the application of vitreous enamel to cast iron, "blisters" may form in the enamel. The Bureau of Standards, in response to a request from the American Ceramic Society, undertook a study of this phenomenon and obtained data from which the following conclusions were drawn.

Physical defects in the castings, especially "sponginess," will cause blisters, as will also faulty composition or application of enamels. There are, however, differences in the tendencies of different sound castings to give blisters when enameled under identical conditions. The gases forming these blisters are $\mathrm{CO}$ and

A gray iron casting acquires in freezing and cooling a very thin surface skin, or "microchill," of varying thickness and hardness. The data indicate that removal of this skin from sound castings eliminates blistering. During the enameling process the combined carbon of this skin tends to break down to a nascent, readily oxidizable form of carbon, which evolves $\mathrm{CO}$ and $\mathrm{CO}_{2}$. There are probably two kinds of nonblistering iron, one in which little combined carbon is present at the surface, and another in which it is stabilized. Some irons are more prone to give the "microchilled" layer than others. During the early stages of enameling both blistering and nonblistering irons evolve gas, which is attributed to quick oxidation of submicroscopic graphite and which escapes before the enamel has fused to a retentive condition. Addition of graphitizing agents, such as silicon, may be beneficial, but it is harder to prevent the formation of the microchill than the ordinary, or macrochill. Removal of the surface layer by deep sandblasting or "burning out" appears to be the most practical remedy for blistering of sound castings.
\end{abstract} $\mathrm{CO}_{2}$.

\section{CONTENTS}

I. Introduction

1. General discussion

(a) Blistering a trouble in enameling

(b) Enameling processes

(c) Blisters and gas evolution

(d) Variations in usual enameling practice that affect blistering .

2. Ideas on blistering expressed by enamelers

II. Preliminary series.

1. Cooperative work and preliminary experiments

2. Heating curve of ground coat.

3. Change in form of test plate.

4. Continuity of ground coat

III. Standardization of test procedure and study of additional variables $\quad 766$

1. Method of rating . .

2. Composition and application of enamel

3. New irons obtained _............ 768

4. Study of several variables-manganese-sulphur ratio, phosphorus content, combined carbon content, carbonaceous facings . . . . . . .

5. Nonblistering iron becomes blistering on remelting

6. "Baking" process and water adsorption tests.......

IV. The range method of firing and its applications

V. Further cooperative experiments

1. Outline of procedure

2. Results obtained. 
VI. Effect of the surface layer of castings on their enameling properties..

1. Importance of cleaning operation

2. Surface removal eliminates blisters..................

3. Additions of softening agents, also phosphorus and fused sodium carbonate

4. Sand-blasting tests

5. Study of burned-in molding sand

6. Composition of surface layers

7. Microscopic examination of "microchilled" layer.

8. Effect of nitrogen

9. Spectroscopic examination

10. Effect of chromium

VII. Erratic behavior of pig iron

VIII. Study of gases and gas-forming elements.....

1. Oxygen...

2. Hydrogen

3. Sulphur

4. Gas in blisters

5. Gas from iron alone heated in nitrogen

6. Gas from iron alone heated in air.

7. Gas from enamel-coated irons heated in nitrogen

8. Gas from iron and enamel heated in air

9. Rate of carbon oxidation

10. Correlation of gas evolution data with previous data.

IX. Study of carbon in the microchilled surface

1. Ordinary graphite

2. Submicroscopic graphite

3. Combined and temper carbons

4. Change of hardness and structure on enameling

5. Burning out

6. Effect of elements in cast iron on chilling tendency

(a) Silicon

(b) Phosphorus

(c) Sulphur and manganese....

X. Summary

XI. Acknowled...-

XII. Selected bibliography

\section{INTRODUCTION}

\section{GENERAL DISCUSSION}

\section{(a) BLISTERING A TROUBLE IN ENAMELING}

In the application of vitreous enamel to cast iron, as in the manufacture of household ranges, bathtubs, etc., "blisters" may form in the enamel. Blistered enamel ware is rough, unsightly, and often unserviceable.

The research committee of the enamel division of the American Ceramic Society brought the problem of blisters to the attention of the Bureau of Standards in 1924. It was stated that some cast irons were more prone to this defect than others and the problem was, therefore, studied from both the metallurgical and the ceramic points of view.

\section{(b) ENAMELING PROCESSES}

The enameling process may be carried out in several ways, depending on the type of enamel used. In the so-called dry process a suspension of enamel is sprayed or painted on a cold casting and dried, after which the coated casting is heated until this first or "ground" coat is matured. A dry second or "cover" coat is then sifted onto the hot ground coat and the piece at once reheated to mature the cover coat. 
The wet process is similar to the dry process in the application of a ground coat, but the piece is then cooled and the cover coat applied in the same way as the ground coat. This is the process with which the present investigation is primarily concerned, because it is believed to furnish a better criterion of blistering tendencies than the dry process. In the two-coat processes the ground coat is more infusible than the cover coat and in firing a higher temperature is used.

In the so-called "single-coat" (wet) process the same enamel is used in the first coat as in any subsequent coat or coats, but the first coat receives a somewhat more severe firing treatment. Such singlecoat enamels are usually more fusible than the two-coat wet-process enamels, often being high in lead oxide in order to produce this fusibility. The firing is done at much lower temperatures than in the other processes.

\section{(c) BLISTERS AND GAS EVOLUTION}

It is obvious that blisters are caused by gas entrapped in the enamel. Craters are evidence of the previous presence of blisters, the enamel not closing completely after the escape of the gas. Slight "dimples" will result when the enamel closes, but does not become quite level; if the enamel does become level obviously no harm is done through the previous existence of the bubble. Hence, it is not gas evolution in itself that is to be feared, but gas evolution at the wrong time. The more fluid and fusible the enamel the less likely it is to entrap bubbles or to leave a crater after a bubble breaks.

(d) VARIATIONS IN USUAL ENAMELING PRACTICE THAT AFFECT BLISTERING

The firing is a rather delicately balanced operation which is affected by changes in the rate at which heat is taken up by the load (as with loads of different weight or different weight-area ratio) or in the rate at which heat is supplied to the furnace. By manipulation of operating conditions, experienced operators can often successfully enamel irons which show some tendency to blister.

Whatever the source of the gas responsible for blisters in enamel coats, if it is evolved before the enamel starts to fuse, it is not retained in the enamel. If it is evolved while the enamel is semifluid and very viscous (under fired), it may be retained. If evolved when the enamel is fluid, it may do no harm unless it is evolved so slowly that it is not released before the enameled article is removed from the furnace. It is quite possible that a "nonblistering" iron might give off more gas, but give it off more readily and more nearly at one temperature, than a "blistering" iron.

\section{IDEAS ON BLISTERING EXPRESSED BY ENAMELERS}

Various facts or opinions in regard to the occurrence of and causes for blisters have been expressed by enamelers though not all of the comments were available at the beginning of the work. These are as follows:

Northern pig iron is said to produce castings which show a greater tendency to the blistering phenomenon than castings from southern pig iron, even though the castings may have closely similar chemical composition. Not all northern irons give trouble from blisters, and Malinovsky $(1)^{1}$ cites a case of blistering of southern iron. The

1 The figures given in parentheses here and throughout the text relate to the reference numbers in the selected bibliography given at the end of this paper. 
outstanding difference between northern and southern pig irons as classes is the higher phosphorus content and consequent greater fluidity of the southern iron.

Remelting of northern pig, or the admixture of 30 to 50 per cent of southern pig iron, scrap, or remelted northern pig iron with 50 to 70 per cent of virgin northern pig iron is said to reduce the tendency toward blistering. This allegation has not been definitely proved.

A British visitor stated that similar troubles met in British practice were avoided by ceasing to use pig iron from certain blast furnaces: Another British comment (2) elaborates this by stating that pig iron from slow-driven blast furnaces is considered to give fewer enameling defects, including blisters, than that from rapidly driven furnaces.

Pig iron with high manganese content is said to cause blisters. Excessively high sulphur content is also asserted to cause blisters and pinholes (2).

White iron castings for malleableizing are said to cause. blisters unless properly "annealed." Gray cast-iron plates chilled on one side only are said to show a greater tendency to blistering on the chilled side. On the other hand, Staley (3, p. 140) states that it was once believed that white iron was the only kind suitable for enameling and cites Vogel as advocating a white chilled layer on gray iron for enameling purposes. Staley states that low-silicon iron, low in graphite, gives less trouble from blisters than does high-silicon iron and ascribes the effect of graphite to its reaction with metallic oxides of the enamel with the formation of carbon monoxide or dioxide gas. He states that the higher the phosphorus content of the iron the lower the silicon can be; hence, indirectly, high phosphorus tends to prevent blisters. Malinovsky (1), on the other hand, alleges that low combined carbon - that is, high graphitic carbon-favors freedom from blisters and high combined carbon produces the opposite result. He states that if temper carbon is present, blistering is certain.

The use of charcoal, sea coal, plumbago, or other carbonaceous facings on a sand mold in which a casting is made that is to be enameled is said to be detrimental. Staley (3, p. 134) advises complete avoidance of all facings. On the other hand, one enameler (while preferring to avoid charcoal facings) advocates the use of plumbago facings and pouring the metal rather cold, with the object of preventing the burning on of a layer of molding sand which may be difficult to remove by sand-blasting.

A casting which has blistered on the first attempt to enamel it, if cleaned from enamel by sand-blasting, may ordinarily be reenameled without further trouble from blistering. Heating the castings to redness (so-called "annealing" or "burning out") before sandblasting is the generally accepted preventive of blistering. In some cases, blistering was said to be prevented by coating the sand-blasted surface with sodium dichromate solution, with the idea of increasing the oxidation of the surface, heating to redness and sand-blasting again. Danielson and Reinecker (4) made heating at $815^{\circ} \mathrm{C}$. $\left(1,500^{\circ} \mathrm{F}\right.$.) prior to sand-blasting the regular practice in their study of the properties of enamels for cast iron.

Thorough cleaning of cast iron by sand-blasting before enameling has been recognized as desirable, to avoid blistering $(5,7)$.

It has been stated that dry-process enamels can usually be applied without blistering to irons that will blister with a wet-process enamel. 
Enamels of improper composition may be blistering of themselves; for example, a ground coat containing over 10 per cent $\mathrm{Na}_{2} \mathrm{O}$ caused blistering (4, p. 719).

An enamel which is free from blisters when applied in proper amount may blister when too heavy a coat is applied irrespective of the composition of the metal to which it is applied (6). In a 2-coat process, if the cover coat is too high-melting in comparison with the ground coat, blisters will result (4, p. 719). It is stated (4, p. 734) that white single-coat enamels containing more than 3 to 4 per cent $\mathrm{SnO}_{2}$ applied on cast iron, even after "burning out," caused blistering. This is ascribed to reduction of $\mathrm{SnO}_{2}$ by graphite.

Contamination of enamel with sulphur, sulphates, greases, or other organic matter, anything that gives volatile products on heating, may cause blisters (3).

\section{PRELIMINARY SERIES}

\section{COOPERATIVE WORK AND PRELIMINARY EXPERIMENTS}

At the outset of the experimental work, it was planned that specimens representing such metallurgical variations as it was wished to study were to be made at the bureau and distributed to cooperating enamelers who would, without divulging the composition of the enamels used, enamel and return the specimens with a description of the process employed.

Northern pig irons, designated as $R_{1}$ and $L_{1}$, were supplied by the committee for these tests, which were especially designed to determine whether remelting was beneficial, as had been claimed. Iron $R_{1}$ proved to have only a slight blistering tendency while iron $L_{1}$ was strongly blistering.

Both cupola and electric furnace melting were tried. The cupola was a small experimental unit, lined to $16 \frac{1}{2}$ inches inside diameter. The tuyères were 17 inches from the bottom. The coke used contained 89.65 per cent fixed carbon, 9.25 per cent ash, 1 per cent volatile, 0.10 per cent moisture, 0.89 per cent sulphur, 0.016 per cent phosphorus, and had 49 per cent cell space. A representative charge was as follows: 170 pounds coke on the bed, then 100 pounds iron, 40 pounds coke, 100 pounds iron, 40 pounds coke, 100 pounds iron. To each layer of iron was added $2 \frac{1}{2}$ pounds oyster shells as flux. In such a heat, the first iron appeared in 8 minutes after starting the blast, the first tap being made in 18 minutes, and the last in 40 minutes. The blast entered at 4 -ounce pressure and the volume of air used varied between 380 and 440 cubic feet per minute until the last 10 minutes when it rose to 500 to 540 . Optical pyrometer readings of the stream of molten iron at tapping, corrected for deviation from black body radiation, gave $1,310^{\circ} \mathrm{C}$. $\left(2,390^{\circ} \mathrm{F}\right.$.) at the first tap and $1,380^{\circ} \mathrm{C}$. $\left(2,520^{\circ} \mathrm{F}\right.$.) on succeeding taps.

The electric furnace was a magnesite lined, indirect arc, rocking type furnace holding about 300 pounds of iron. It was operated at 80 to 105 volts, 1,100 to 1,400 amperes (momentary readings). The average power input was $75 \mathrm{kw}$. In a representative heat of 325 pounds iron, charged into a cold furnace, the metal was melted after $140 \mathrm{kw}$. h. had been used. Rocking of the furnace was then started. After $2 \frac{1}{2}$ hours with a total input of $190 \mathrm{kw}$. h., the metal was at $1,480^{\circ}$ C. $\left(2,700^{\circ} \mathrm{F}.\right)$. Unlike the small cupola, the electric furnace 
could be made to deliver the metal at any desired temperature, and was much more satisfactory to use on an experimental scale.

The change in composition on repeated cupola melting and the much smaller change on electric melting are shown in Table 1.

It will be noted that, in cupola melting under the test conditions, the total carbon, the manganese, and the silicon decreased as a result of oxidation, whereas the sulphur increased on account of sulphur "pick up" from the coke.

In the electric furnace the total carbon, the silicon, and especially the manganese, changed very little, and there was no pick up of sulphur. When close control of the composition for experimental purposes was necessary, it was therefore much easier to use the electric furnace than the cupola.

The form of the castings used in the first part of this investigation is shown in Figure 1.

Plates from the heats given in Table 1 (except heat 21) and from several other heats to which additions of arsenic, tin, and sulphur (added as iron sulphide) had been made, were enameled either at the bureau alone, or with different enamels at the bureau and cooperating plants, and examined for blisters.

TABLE 1.-Change in composition of pig iron on repeated meltings in cupola and electric furnace

\begin{tabular}{|c|c|c|c|c|c|c|c|c|c|}
\hline \multirow{2}{*}{ Iron } & \multirow{2}{*}{ Furnace and melt } & \multirow{2}{*}{$\begin{array}{l}\text { Heat } \\
\text { No. }\end{array}$} & \multicolumn{3}{|c|}{ Carbon } & \multirow{2}{*}{$\mathrm{Mn}$} & \multirow{2}{*}{$\mathbf{P}$} & \multirow{2}{*}{$\mathrm{S}$} & \multirow{2}{*}{$\mathrm{Si}$} \\
\hline & & & Total & $\begin{array}{l}\text { Gra- } \\
\text { phitic }\end{array}$ & $\begin{array}{l}\text { Com- } \\
\text { bined }\end{array}$ & & & & \\
\hline $\begin{array}{l}R_{1-\cdots} \\
R_{1-\cdots} \\
R_{1-\cdots} \\
R_{1-\cdots}\end{array}$ & 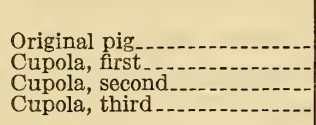 & $\begin{array}{r}7 \\
12 \\
13\end{array}$ & \begin{tabular}{|c|} 
Per cent \\
3.62 \\
3.40 \\
3.25 \\
3.22
\end{tabular} & \begin{tabular}{|c} 
Per cent \\
3.06 \\
3.18 \\
2.84 \\
2.74
\end{tabular} & $\begin{array}{r}\text { Per cent } \\
0.55 \\
.22 \\
.41 \\
.48\end{array}$ & $\begin{array}{r}\text { Per cent } \\
0.78 \\
.69 \\
.57 \\
.44\end{array}$ & $\begin{array}{c}\text { Per cent } \\
0.83 \\
.81 \\
.84 \\
.84\end{array}$ & $\begin{array}{c}\text { Per cent } \\
0.029 \\
.048 \\
.058 \\
.086\end{array}$ & $\begin{array}{r}\text { Per cent } \\
2.99 \\
2.82 \\
2.77 \\
2.69\end{array}$ \\
\hline $\begin{array}{l}R_{1--} \\
R_{1--} \\
R_{1--} \\
L_{1--}\end{array}$ & $\begin{array}{l}\text { Electric, first } \\
\text { Electric, second } \\
\text { Original pig... }\end{array}$ & $\begin{array}{r}9 \\
23 \\
11\end{array}$ & $\begin{array}{l}3.62 \\
3.66 \\
3.76 \\
3.81\end{array}$ & $\begin{array}{l}3.05 \\
3.17 \\
3.28 \\
3.15\end{array}$ & $\begin{array}{l}.57 \\
.49 \\
.48 \\
.66\end{array}$ & $\begin{array}{l}.73 \\
.73 \\
.71 \\
.67\end{array}$ & $\begin{array}{l}.80 \\
.80 \\
.79 \\
.46\end{array}$ & $\begin{array}{l}.026 \\
.023 \\
.030 \\
.045\end{array}$ & $\begin{array}{l}2.30 \\
2.77 \\
2.85 \\
2.31\end{array}$ \\
\hline $\begin{array}{l}L_{1} \ldots \ldots . \\
L_{1} \ldots \ldots . \\
L_{1} \ldots \ldots \\
L_{1} \ldots \ldots .\end{array}$ & $\begin{array}{l}\text { Cupola, first } \\
\text { Cupola, second } \\
\text { Cupola, third } \\
\text { Cupola, fourth }\end{array}$ & $\begin{array}{r}6 \\
14 \\
15 \\
16 \\
21\end{array}$ & $\begin{array}{l}3.65 \\
3.47 \\
3.51 \\
3.47 \\
3.34\end{array}$ & $\begin{array}{l}2.97 \\
3.07 \\
2.74 \\
2.95 \\
1.89\end{array}$ & $\begin{array}{r}.68 \\
.40 \\
.77 \\
.52 \\
1.45\end{array}$ & $\begin{array}{l}.56 \\
.57 \\
.42 \\
.33 \\
.24\end{array}$ & $\begin{array}{l}.46 \\
.46 \\
.46 \\
.47 \\
.46\end{array}$ & $\begin{array}{l}.050 \\
.076 \\
.083 \\
.095 \\
.108\end{array}$ & $\begin{array}{l}2.16 \\
2.24 \\
2.07 \\
1.92 \\
1.70\end{array}$ \\
\hline $\begin{array}{l}L_{1-\ldots} \\
I_{1-\ldots} \\
I_{1-\ldots}\end{array}$ & $\begin{array}{l}\text { Cupola, fifth } \\
\text { Electric, first. }\end{array}$ & $\begin{array}{r}25 \\
8 \\
17 \\
10\end{array}$ & $\begin{array}{l}3.20 \\
3.67 \\
3.76 \\
3.97\end{array}$ & $\begin{array}{r}.99 \\
3.16 \\
3.10 \\
3.34\end{array}$ & $\begin{array}{r}2.21 \\
.51 \\
.66 \\
.63\end{array}$ & $\begin{array}{l}.18 \\
.62 \\
.63 \\
.62\end{array}$ & $\begin{array}{l}.47 \\
.47 \\
.47 \\
.44\end{array}$ & $\begin{array}{l}.125 \\
.048 \\
.038 \\
.017\end{array}$ & $\begin{array}{l}1.51 \\
2.32 \\
2.19 \\
2.19\end{array}$ \\
\hline
\end{tabular}

With dry-process enamel, all specimens enameled at the bureau behaved excellently except for a few large blisters on heat 25 , iron $L_{1}$, which as a result of remelting (five times in the cupola) had very high combined carbon and low silicon. One firm, using a dry-process enamel, reported satisfactory results on various heats of both $R_{1}$ and $\mathrm{I}_{1}$ except heat 25. Another firm, using dry-process enamel, also reported good results with $R_{1}$ and some specimens of $L_{1}$ whether from cupola or electric furnace in the case of first melts in which the sulphur had been raised to 0.10 to 0.12 per cent. They reported poor results, however, with the electric furnace melts not having sulphur additions and with the $\mathrm{L}_{1}$ cupola remelts. 
With wet-process enamels, one cooperating firm used no ground coat, but instead two coats of a very low melting white enamel. They reported severe blistering on all specimens of both irons. However, by merely increasing the firing time on the second coat from 12 to 17 minutes, a great improvement resulted on the few repeat tests that were made, some specimens being practically perfect.

At the bureau, specimens coated with ground coat $\mathrm{Rg}-1$, fired at $900^{\circ} \mathrm{C}$. $\left(1,650^{\circ} \mathrm{F}\right.$.) and followed by a white cover coat, $\mathrm{R}-14$, blistered badly. The compositions of ground and cover coats are given in Tables 2 and 3.

TABLE 2.-Composition of ground coat $R g-1^{1}$

COMPOSITION OF MELTED FRIT

\begin{tabular}{c|c|c|c|c}
\hline Ground coat No. & Flint & $\mathrm{B}_{2} \mathrm{O}_{3}$ & $\mathrm{Na}_{2} \mathrm{O}$ & $\mathrm{PbO}$ \\
\cline { 2 - 4 } & $\begin{array}{r}\text { Per cent } \\
69.90\end{array}$ & $\begin{array}{r}\text { Per cent } \\
13.57\end{array}$ & $\begin{array}{r}\text { Per cent } \\
8.53\end{array}$ & $\begin{array}{r}\text { Per cent } \\
8.00\end{array}$ \\
\hline
\end{tabular}

COMPOSITION OF BATCH; 100 PARTS OF MELTED FRIT

\begin{tabular}{c|c|c|c|c}
\hline Ground coat No. & Flint & Borax & $\begin{array}{r}\text { Sodium } \\
\text { nitrate }\end{array}$ & Red lead \\
\cline { 2 - 4 } & $\begin{array}{rlr}\text { Per cent } \\
69.90\end{array}$ & $\begin{array}{r}\text { Per cent } \\
36.96\end{array}$ & $\begin{array}{r}\text { Per cent } \\
6.95\end{array}$ & $\begin{array}{r}\text { Per cent } \\
8.17\end{array}$ \\
\hline
\end{tabular}

1 Ground coat Rg-1, B. S. Tech. Paper No. 246, pp. 702, 703 (used with 15 per cent clay).

TABLI 3.-Composition of white cover enamels $R-11$ and $R-14^{1}$ COMPOSITION OF MELTED FRIT

\begin{tabular}{|c|c|c|c|c|c|c|c|c|}
\hline Enamel No. & $\begin{array}{l}\text { Feld- } \\
\text { spar }\end{array}$ & Flint & $\mathrm{B}_{2} \mathrm{O}_{3}$ & $\mathrm{Na}_{2} \mathrm{O}$ & $\mathrm{PbO}$ & $\mathrm{ZnO}$ & $\mathrm{CaF}_{2}$ & $\begin{array}{l}\text { Cryo- } \\
\text { lite }\end{array}$ \\
\hline 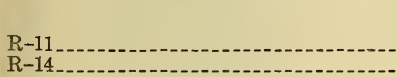 & $\mid \begin{array}{r}\text { Per cent } \\
33.0 \\
38.0\end{array}$ & $\begin{array}{r}\text { Per cent } \\
12.0 \\
12.0\end{array}$ & $\begin{array}{c}\text { Per cent } \\
9.0 \\
4.0\end{array}$ & $\begin{array}{r}P e r \text { cent } \\
8.5 \\
8.5\end{array}$ & $\mid \begin{array}{r}\text { Per cent } \\
21.0 \\
21.0\end{array}$ & $\mid \begin{array}{r}\text { Per cent } \\
6.0 \\
6.0\end{array}$ & $\begin{array}{r}\text { Per cent } \\
5.5 \\
5.5\end{array}$ & $\begin{array}{r}\text { Per cent } \\
5.0 \\
5.0\end{array}$ \\
\hline
\end{tabular}

COMPOSITION OF BATCH; 100 PARTS OF MELTED FRIT

\begin{tabular}{|c|c|c|c|c|c|c|c|c|c|}
\hline Enamel No. & $\begin{array}{l}\text { Feld- } \\
\text { spar }\end{array}$ & Flint & Вогах & $\begin{array}{l}\text { Sodium } \\
\text { nitrate }\end{array}$ & $\begin{array}{c}\text { Soda } \\
\text { ash }\end{array}$ & $\begin{array}{l}\text { Red } \\
\text { lead }\end{array}$ & $\begin{array}{l}\text { Zinc } \\
\text { oxide }\end{array}$ & $\begin{array}{l}\text { Fluor- } \\
\text { spar }\end{array}$ & $\begin{array}{c}\text { Cryo- } \\
\text { lite }\end{array}$ \\
\hline -14_...-- & $\begin{array}{c}\text { Per cent } \\
33.0 \\
38.0\end{array}$ & $\begin{array}{c}\text { Per cent } \\
12.0 \\
12.0\end{array}$ & $\begin{array}{c}\text { Per cent } \\
24.52 \\
10.90\end{array}$ & $\mid \begin{array}{r}\text { Per cent } \\
6.20 \\
6.20\end{array}$ & $\begin{array}{c}\text { Per cent } \\
3.86 \\
7.70\end{array}$ & $\begin{array}{c}\text { Per cent } \\
21.60 \\
21.60\end{array}$ & $\begin{array}{r}\text { Per cent } \\
6.0 \\
6.0\end{array}$ & $\mid \begin{array}{r}\text { Per cent } \\
5.5 \\
5.5\end{array}$ & $\begin{array}{r}\text { Per cent } \\
5.0 \\
5.0\end{array}$ \\
\hline
\end{tabular}

1 White cover enamels R-11 and R-14, B. S. Tech. Paper No. 246, pp. 708-709.

One firm enameled some specimens with wet-process enamel, the ground coat being fired at $870^{\circ} \mathrm{C}$. $\left(1,600^{\circ} \mathrm{F}\right.$.) for eight minutes, the cover coat at $840^{\circ} \mathrm{C}$. $\left(1,545^{\circ} \mathrm{F}\right.$.) for seven minutes (composition of enamels not given). The results of these tests are shown in Table 4, together with similar ones carried out at the bureau, rated on a scale in which 100 represents a perfect piece with no blisters and 0 a piece with an average of one or more blisters per square inch (18 blisters on the 18 square inch specimen). 
One might conclude that iron $R_{1}$ is, on the whole, not a "blistering" iron, whereas $L_{1}$ is a strongly "blistering" iron. From the results of the bureau tests of $L_{1}$ heats $14,15,16$, and 25 , one would conclude that remelting in the cupola made the iron worse, while from the tests made under commercial conditions no definite conclusion could be drawn. However, it is plain that mere remelting is by no means a "cure-all" for blistering. The results with heats $\mathrm{L}_{1}, 22$ and 27 , suggest that an increase in the sulphur content to 0.10 to 0.12 per cent would help, but when sulphur was added in heat $\mathrm{L}_{1}-28$ (Table 4) this conclusion was not verified.

A few heats of iron $\mathrm{L}_{1}$ were made with additions of tin or arsenic, but no beneficial results were observed.

Inconclusive results were also obtained from some experiments (2-coat, wet-process enamel on iron $\mathrm{L}_{1}$, heat 14, Table 4) in an effort to study the possibilities of surface treatment, aimed to remove carbon or graphite from the surface before enameling.

TABLE 4.-Comparison of tests on iron with wet-process enamel

\begin{tabular}{|c|c|c|c|c|c|c|c|c|c|c|c|c|}
\hline \multirow[b]{2}{*}{ Iron } & \multirow[b]{2}{*}{ Heat } & \multirow[b]{2}{*}{$\begin{array}{c}\text { Number } \\
\text { of } \\
\text { times } \\
\text { through }\end{array}$} & \multicolumn{3}{|c|}{ Carbon } & \multirow[b]{2}{*}{ Mn } & \multirow[b]{2}{*}{$\mathbf{P}$} & \multirow[b]{2}{*}{$\mathrm{S}$} & \multirow[b]{2}{*}{$\mathrm{Si}$} & \multirow[b]{2}{*}{$\begin{array}{l}\mathrm{Mn} / \mathrm{S} \\
\text { ratio }\end{array}$} & \multicolumn{2}{|c|}{ Rating } \\
\hline & & & $\begin{array}{l}\text { To- } \\
\text { tal }\end{array}$ & $\underset{\text { ite }}{\text { Graph- }}$ & $\begin{array}{l}\text { Com- } \\
\text { bined }\end{array}$ & & & & & & $\begin{array}{c}\text { Bu- } \\
\text { reau } \\
\text { of } \\
\text { Stand- } \\
\text { ards }\end{array}$ & $\begin{array}{l}\text { Com- } \\
\text { mer- } \\
\text { cial } \\
\text { firm }\end{array}$ \\
\hline$L_{1} \ldots$ & 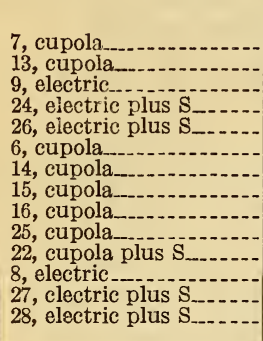 & 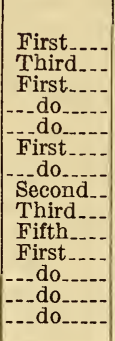 & \begin{tabular}{r|} 
P. ct. \\
3.40 \\
3.22 \\
3.62 \\
3.64 \\
3.58 \\
3.65 \\
3.47 \\
3.51 \\
3.47 \\
3.20 \\
3.59 \\
3.67 \\
3.75 \\
3.67
\end{tabular} & \begin{tabular}{l|} 
P.ct. \\
3. 18 \\
2.74 \\
3.05 \\
3.16 \\
3.09 \\
2.97 \\
3.07 \\
2.74 \\
2.95 \\
.99 \\
2.99 \\
3.16 \\
3.19 \\
3.09
\end{tabular} & \begin{tabular}{r|}
$P . c t$. \\
0.22 \\
.48 \\
.57 \\
.48 \\
.49 \\
.68 \\
.40 \\
.77 \\
.52 \\
2.21 \\
.60 \\
.51 \\
.56 \\
.58
\end{tabular} & $\begin{array}{r}P . c t . \\
0.68 \\
.44 \\
.73 \\
.74 \\
.77 \\
.56 \\
.57 \\
.42 \\
.33 \\
.18 \\
.56 \\
.62 \\
.65 \\
.61\end{array}$ & \begin{tabular}{|l|}
$P . c t$ \\
0.81 \\
.84 \\
.80 \\
.77 \\
.79 \\
.46 \\
.46 \\
.46 \\
.47 \\
.47 \\
.45 \\
.47 \\
.43 \\
.44
\end{tabular} & $\begin{array}{l}\text { P.ct. } \\
0.048 \\
.086 \\
.026 \\
.110 \\
.090 \\
.050 \\
.076 \\
.083 \\
.095 \\
.125 \\
.121 \\
.048 \\
.105 \\
.092\end{array}$ & $\begin{array}{l}P . c t . \\
2.82 \\
2.69 \\
2.90 \\
2.75 \\
2.93 \\
2.16 \\
2.24 \\
2.07 \\
1.92 \\
1.51 \\
2.22 \\
2.32 \\
2.30 \\
2.21\end{array}$ & $\begin{array}{r}P . c t . \\
12.2 \\
5.1 \\
28.1 \\
6.7 \\
8.6 \\
10.2 \\
7.5 \\
9.2 \\
3.5 \\
1.4 \\
4.6 \\
13.0 \\
6.2 \\
6.6\end{array}$ & \begin{tabular}{|r|}
$P . c t$. \\
94 \\
89 \\
100 \\
96 \\
72 \\
28 \\
0 \\
0 \\
100 \\
0 \\
83 \\
50
\end{tabular} & $\begin{array}{r}P . c t . \\
100 \\
100 \\
94 \\
0 \\
78 \\
56 \\
67 \\
89 \\
92 \\
83 \\
100 \\
56\end{array}$ \\
\hline
\end{tabular}

Sand-blasted specimens of "blistering" iron were covered with commercial grades of red lead, red iron oxide, and black iron oxide, respectively, and heated to $925^{\circ} \mathrm{C}$. $\left(1,700^{\circ} \mathrm{F}\right.$.) for 10 minutes. Much of the lead oxide was volatilized during heating. After lightly cleaning the surface and enameling, no distinct or significant difference was found between the blistering of specimens so treated and that of untreated specimens.

Specimens of irons $L_{1}$, heat 17 , and $R_{1}$, heat 7 , were lightly sandblasted and heated in steam for about an hour at $500^{\circ} \mathrm{C}$. (930 $0^{\circ} \mathrm{F}$.), in order to produce a thin adhering coating of oxide on the surface. Part of each specimen was then lightly ground down in order to clean it from oxide and the 2-coat wet-process enamel applied over the entire surfaces. With the weakly blistering iron, $\mathrm{R}_{1}$, the oxidized surface blistered badly, while the metallic surface was almost free from blisters. With the strongly blistering iron, $L_{1}$, both the oxidized and the metallic surfaces blistered badly, 
B. S. Journal of Research, RP179
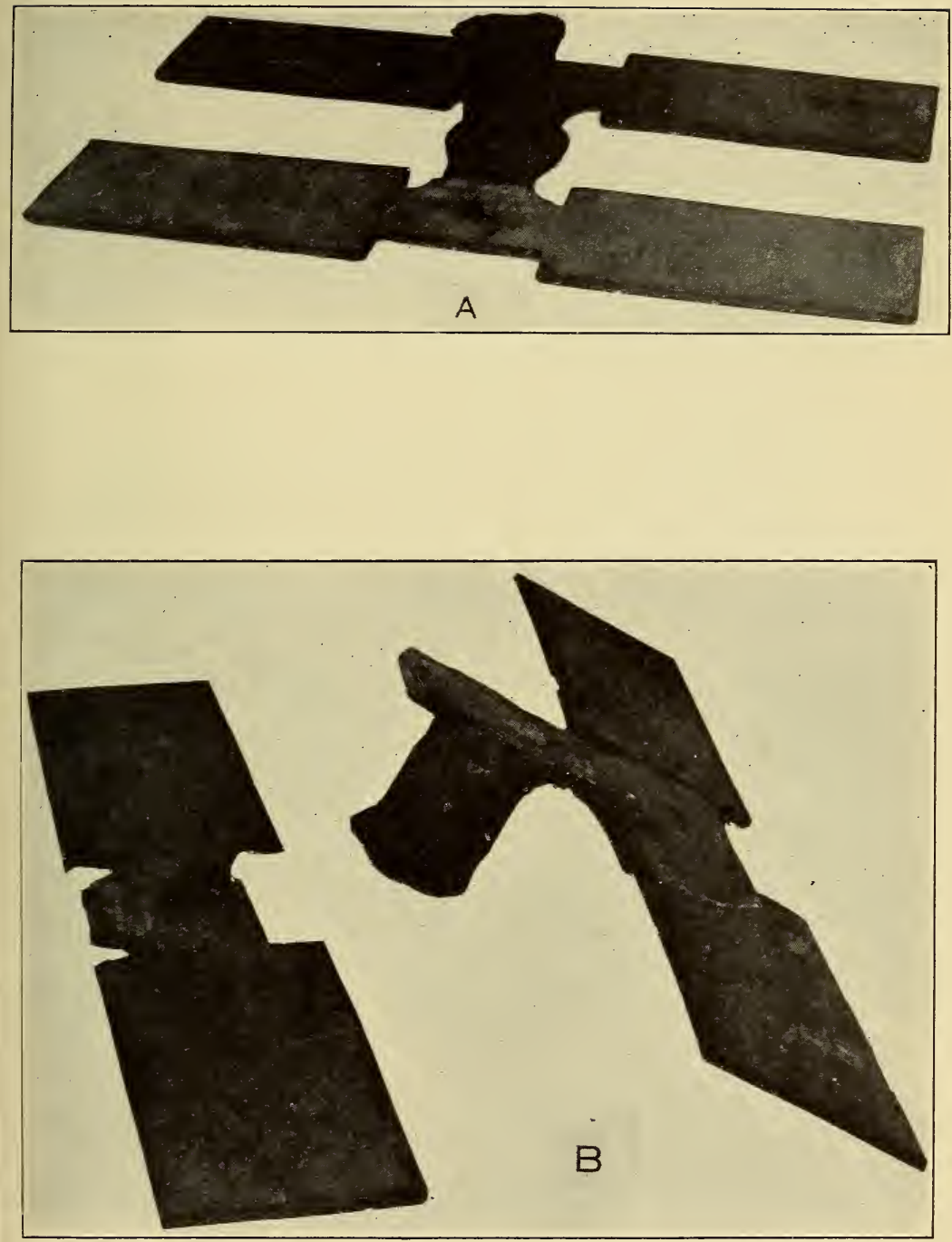

FIgURE 1.-Specimens (3 by 6 by $3 / 16$ inch) cast four at a time $A$, Cope side, gate in the middle; $B$, drag side of same casting 
B. S. Journal of Research, RP179

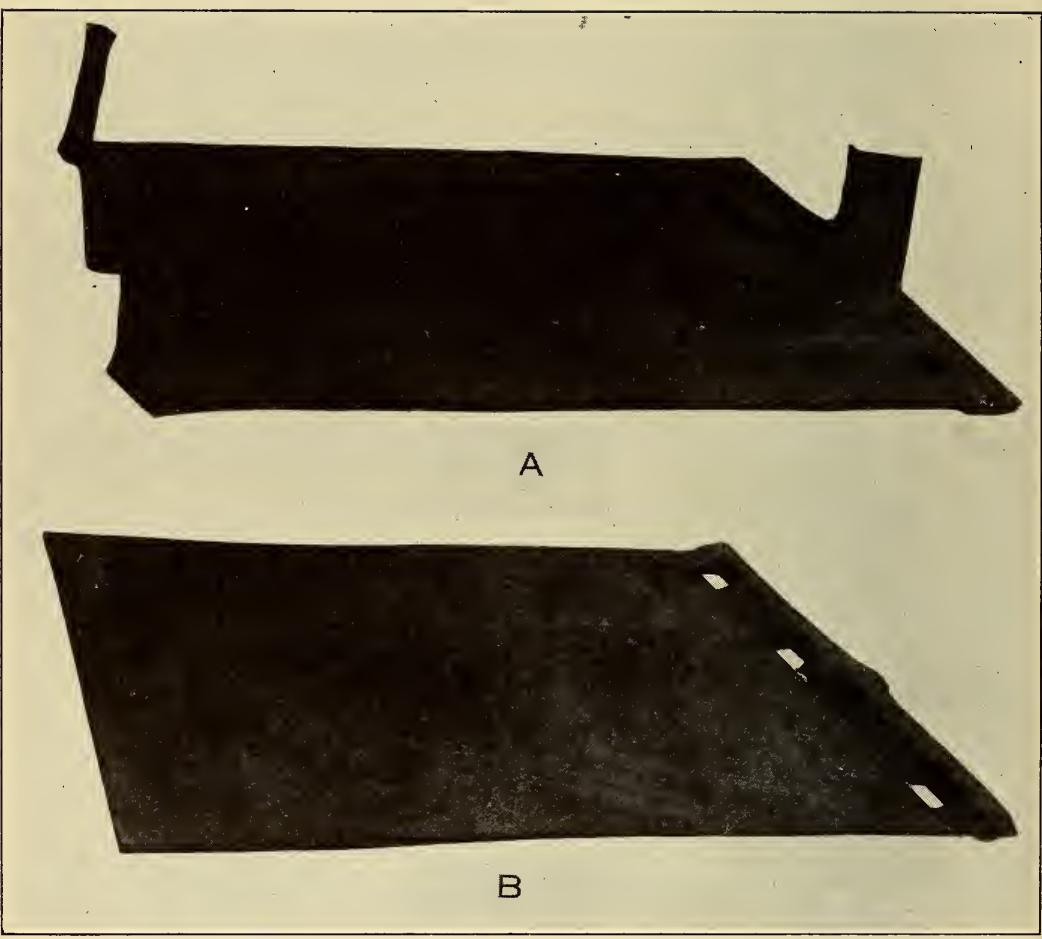

Figure 3.-Specimens (3 by 6 by $3 / 16$ inch) cast 18 in 1 plate $A$, Cope side, with gate and risers; $B$, drag side of same casting. 


\section{HEATING CURVE OF GROUND COAT}

From a heating curve (fig. 2) of the ground coat mixture, it was evident that the firing temperature used in the early work, $900^{\circ} \mathrm{C}$. $\left(1,650^{\circ} \mathrm{F}.\right)$, was far above the sintering point of the material. Consequently the firing temperature for a number of the following tests was reduced to $760^{\circ}$ to $800^{\circ} \mathrm{C}$. $\left(1,400^{\circ}\right.$ to $1,470^{\circ} \mathrm{F}$.), the firing time being 12 to 15 minutes. The cover coat $\mathrm{R}-11$ was fired at $680^{\circ}$ to $710^{\circ} \mathrm{C}$. $\left(1,255^{\circ}\right.$ to $1,310^{\circ} \mathrm{F}$.) for 6 to 9 minutes.

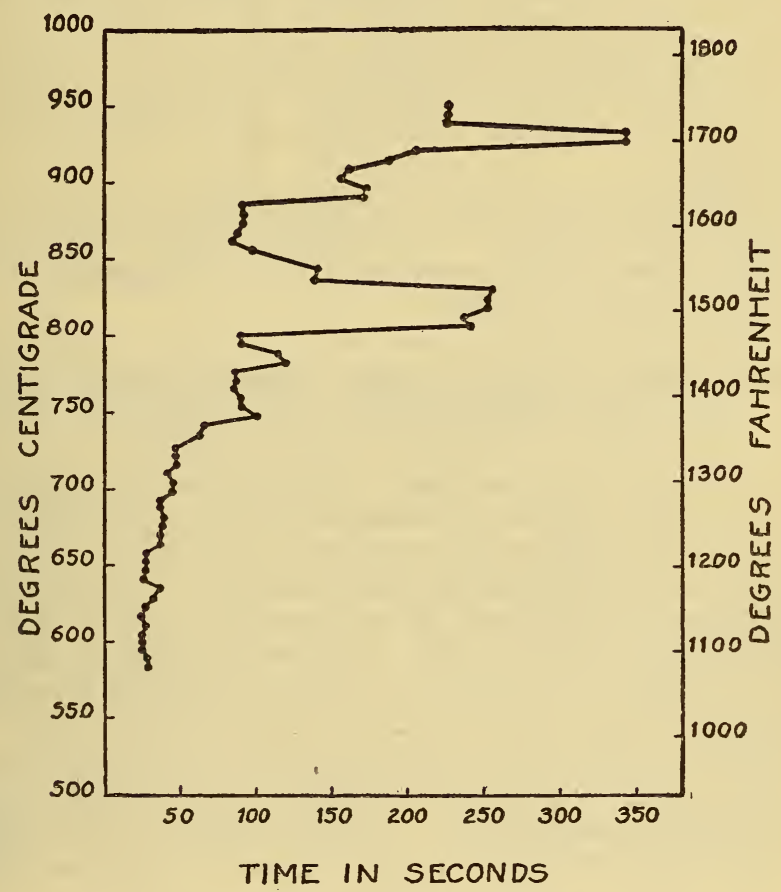

FIGURE 2.-Inverse rate heating curve of enamel

Ground coat powder RG-1 ( +15 per cent clay). Curve shows the time required to raise the temperature of this material a certain number of degrees at different temperatures.

\section{CHANGE IN FORM OF TEST PLATE}

In some cases the blisters on test specimens were thought to be ascribable to porosity of the iron that might result from shrinkage near the gates, from sand holes due to washing of the sand by the stream of metal, or other causes not characteristic of the iron itself. Hence, the small separate specimens, shown in Figure 1, were replaced by a larger plate shown in Figure 3, which was later cut in to specimens of the same size as Figure 1. Direct connection of a gate with a specimen was in this way eliminated. The drag side of the casting was invariably the one coated in the enameling tests. The use of the larger plate and of extreme precautions in making the molds and pouring the metal gave specimens with fewer sand holes, but erratic results still persisted on enameling. 
In some cases a blister in the enamel could be logically ascribed to the presence of some flaw in the casting as shown by grinding down to the metal. The majority of blisters on specimens from the large cast plates, however, appeared to bear no relation to casting flaws.

\section{CONTINUITY OF GROUND COAT}

Another suggested explanation for erratic results was that perhaps the ground coat failed to cover the iron and that blisters resulted at bare spots. Specimens to which the ground coat had been applied were tested by the "ferroxyl indicator" (8). A wall of plasticine was built around the edges to hold the solution until it solidified and two copper wires were immersed in the liquid as a possible means of accelerating the action. In such a test any exposed iron is indicated by a blue precipitate.

No ground-coated specimen was found which was free from bare spots. Since various lots of "nonblistering" iron showed no blisters, it was obvious that blisters need not result necessarily from contact of the cover coat at bare spots.

\section{STANDARDIZATION OF TEST PROCEDURE AND STUDY OF ADDITIONAL VARIABLES}

In view of the inconclusive results obtained in the preliminary series of tests, it was decided that instead of making up a large number of specimens for distribution to commercial enamelers who would use various enamels and enameling procedures, it was best to use only one type of enamel and to do all the enameling under definitely controlled conditions at the bureau. For standardizing the enameling procedure, a supply of commercial castings known to be relatively free from blistering troubles was adopted as nonblistering iron. A standard of time and temperature was adonted for firing both the ground and the cover coat (the ground-coat and cover-coat frits were supplied by the cooperating committee). Blister-free ware was obtained with this iron when the coatings were applied in the weights prescribed.

\section{METFOD OF RATING}

Specimens were selected to be used in rating the enameling results numerically from 1 to $5 ; 1$, excellent; 2 , satisfactory, that is, would probably be just passed by a commercial inspector; 3 , slightly blistered, probably would be rejected; 4 , badly blistered; and 5, very badly blistered.

\section{COMPOSITION AND APPLICATION OF ENAMEL}

The enamel composition and the firing temperatures were maintained constant throughout all the rest of the investigation, though, as will be noted later, the firing periods were not. The composition and method of application of the "standard" ground and cover coats are given in Table 5 . 
TABLE 5.-Composition of standard ground coat and cover coat

\begin{tabular}{|c|c|c|c|c|c|}
\hline \multirow{2}{*}{ Raw material } & \multicolumn{2}{|c|}{ Batch weights } & \multicolumn{3}{|c|}{ Calculated melted compositions } \\
\hline & $\begin{array}{c}\text { Ground } \\
\text { coat }\end{array}$ & $\begin{array}{c}\text { Cover } \\
\text { coat }\end{array}$ & Ingredient & $\begin{array}{c}\text { Ground } \\
\text { coat }\end{array}$ & $\begin{array}{l}\text { Cover } \\
\text { coat }\end{array}$ \\
\hline $\begin{array}{l}\text { Feldspar } \\
\text { Quartz } \\
\text { Borax } \\
\text { Red lead-.....-...- }\end{array}$ & $\begin{array}{r}67.40 \\
37.10 \\
7.35\end{array}$ & $\begin{array}{l}34.70 \\
14.30 \\
24.30 \\
16.05\end{array}$ & $\begin{array}{l}\mathrm{SiO}_{2}-1-1 \\
\mathrm{~B}_{2} \mathrm{O}_{3}- \\
\mathrm{Na}_{2} \mathrm{O} \\
\mathrm{PbO}-\end{array}$ & $\begin{array}{r}\text { Per cent } \\
67.40 \\
17.04 \\
8.35 \\
7.16\end{array}$ & $\begin{array}{r}\text { Per cent } \\
14.30 \\
8.91 \\
7.13 \\
15.70\end{array}$ \\
\hline $\begin{array}{l}\text { Boric acid } \\
\text { Soda niter } \\
\text { Potash niter } \\
\text { Soda ash }\end{array}$ & $\begin{array}{l}6.07 \\
6.39\end{array}$ & $\begin{array}{r}2.73 \\
5.47\end{array}$ & $\begin{array}{l}\text { Feldspar....-. } \\
\mathrm{K}_{2} \mathrm{O} \\
\text { Cryolite } \\
\text { ZnO }\end{array}$ & & $\begin{array}{r}34.70 \\
1.27 \\
4.28 \\
7.02\end{array}$ \\
\hline 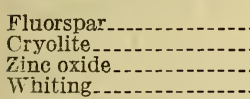 & - n & $\begin{array}{l}5.47 \\
4.28 \\
7.02 \\
2.22\end{array}$ & $\mathrm{CaO}_{2} \mathrm{CaO}_{2}$ & 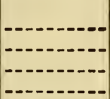 & $\begin{array}{l}1.23 \\
5.47\end{array}$ \\
\hline Total & 124.31 & 116.54 & & 99.95 & 100.01 \\
\hline
\end{tabular}

The above ground and cover coats were furnished by the cooperating committee of the American Ceramic Society. The ground coat was sintered in sheet-iron pans holding about 25 pounds each in a muffle furnace for one hour at $843^{\circ}$ to $871^{\circ} \mathrm{C}$. $\left(1,550^{\circ}\right.$ to $1,600^{\circ} \mathrm{F}$.). The cover enamel was melted in a coal-fired open-hearth smelter in batches of about 700 pounds for about $1 \frac{3 / 4}{4}$ hours.

The special ground coat used for this work was prepared by crushing the frit first in a jaw crusher, to pass a No. 4 sieve, and then milled in 10-pound batches in a 10 by 14 inch porcelain ball mill containing $46 \frac{1}{2}$ pounds of pebbles. The mill batch and milling procedure were as follows:

Frit

Pounds

Water

This was ground three hours (12,000 revolutions), and the following addition made:

Pounds

Water

$-1$

Clay 1.5

This was then ground three-fourths hour (3,000 revolutions), more.

A screen test of the ground coat prepared in this way gave the following results, based on the dry weight of enamel:

Coarser than 115 mesh

Per cent

Through 115 on 200 mesh....... 03

The white cover enamel was also prepared by grinding for three hours (12,000 revolutions), in a porcelain ball mill containing $46 \frac{1}{2}$ pounds of pebbles in 10-pound batches as follows:

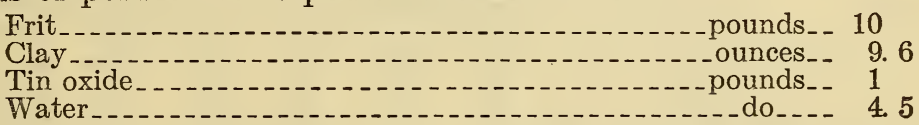

A screen test of the white cover enamel gave the following results based on dry weight of enamel:

Coarser than 115 mesh. 0.06

Through 115 on 200 mesh 2.54

$106307^{\circ}-30-3$ 
The cast-iron specimens to be enameled were prepared by sand blasting with Ottawa sand-blast sand at 25 pounds pressure and then cleaned free from dust. (The time of sand blasting was not specified at this stage of the work.)

The ground coat prepared as above was applied at a specific gravity of 1.53 to give a wet coating of 3 to $4 \mathrm{~g}$ on the test specimens (3 by 6 inches). These were dried in an electric oven at $90^{\circ} \mathrm{C}$. for at least 45 minutes. They were then fired in a gas-fired muffle furnace at $835^{\circ} \mathrm{C}$. $\left(1,535^{\circ} \mathrm{F}\right.$.), for eight minutes (three to eight pieces in a load), and allowed to cool in the air. The temperature drop upon insertion of the load was about $45^{\circ} \mathrm{C}$. ( $81^{\circ} \mathrm{F}$.), recovery being made before the end of the firing period.

The white cover enamel was applied to the ground-coated pieces at a specific gravity of 1.91 to give a wet coating of $23( \pm 1) \mathrm{g}$ on each specimen. The pieces were dried in an electric oven at $90^{\circ} \mathrm{C}$. for at least $1 \frac{1}{2}$ hours. They were kept in the oven at this temperature until ready to be fired and were then fired at $790^{\circ} \mathrm{C}$. $\left(1,455^{\circ} \mathrm{F}\right.$.), for seven minutes (three to eight pieces in a load), the temperature drop upon insertion of the load in this case being about $30^{\circ} \mathrm{C}$. $\left(54^{\circ} \mathrm{F}\right.$.).

Inasmuch as the method called for handling three to eight pieces as a furnace load, in general a load was made up of specimens from different heats, not of duplicate specimens from the same heat of iron. Instead of relying on a single specimen as an indicator of blistering, four or more duplicate specimens were fired in different loads. This procedure at once brought out the fact that duplicate specimens, even under the carefully controlled firing conditions, often did not behave the same as regards the formation of blisters.

\section{NEW IRONS OBTAINED}

The original irons, $R_{1}$ and $L_{1}$, having been nearly exhausted in previous work, similar northern irons, $R_{2}$ (slightly blistering) and $L_{2}$ (strongly blistering) were obtained from the same sources as before. Southern and southern charcoal pig irons were also obtained for comparison.

The compositions of all of the pig irons used are shown in Table 6.

TABLE 6.-Composition of pig irons used in enameling tests

(See Table 16 for content of other elements)

\begin{tabular}{|c|c|c|c|c|c|c|c|c|}
\hline \multirow[b]{2}{*}{ Designation of irons } & \multirow[b]{2}{*}{ Character } & \multicolumn{7}{|c|}{ Composition } \\
\hline & & $\begin{array}{c}\text { Total } \\
\text { carbon }\end{array}$ & $\begin{array}{c}\text { Graphite } \\
\text { carbon }\end{array}$ & $\begin{array}{c}\text { Com- } \\
\text { bined } \\
\text { carbon }\end{array}$ & $\mathrm{Mn}$ & $P$ & S & Si \\
\hline $\begin{array}{l}\text { Southern charcoal } \\
\text { Southern } \\
\mathrm{R}_{1} \\
\mathrm{R}_{2} \\
\mathrm{~L}_{2}\end{array}$ & $\begin{array}{c}\text { Weakly blistering } \\
\text { Blistering } \\
\text { do do } \\
\end{array}$ & \begin{tabular}{|c|} 
Per cent \\
3.82 \\
3.55 \\
3.62 \\
3.61 \\
3.81 \\
3.73
\end{tabular} & $\begin{array}{r}t \text { Per cent } \\
3.40 \\
3.15 \\
3.03 \\
2.96 \\
3.15 \\
3.14\end{array}$ & $\begin{array}{r}\text { Per cent } \\
0.42 \\
.40 \\
.56 \\
.65 \\
.66 \\
.59\end{array}$ & $\begin{array}{c}\text { Per cent } \\
0.17 \\
.24 \\
.78 \\
.68 \\
.67 \\
.78\end{array}$ & $\begin{array}{r}\text { Per cent } \\
0.51 \\
.82 \\
.83 \\
.78 \\
.46 \\
.50\end{array}$ & $\mid \begin{array}{c}\text { Per cent } \\
0.024 \\
.021 \\
.029 \\
.005 \\
.045 \\
.090\end{array}$ & $\begin{array}{r}\text { Per cent } \\
1.75 \\
2.73 \\
2.39 \\
2.66 \\
2.31 \\
2.55\end{array}$ \\
\hline
\end{tabular}


4. STUDY OF SEVERAL VARIABLES-MANGANESE-SULPHUR RATIO, PHOSPHOROUS CONTENT, COMBINED CARBON CONTENT, CARBONACEOUS FACINGS

On the assumption that the average enamel rating might show the presence or absence of a trend, the ratings have been plotted against

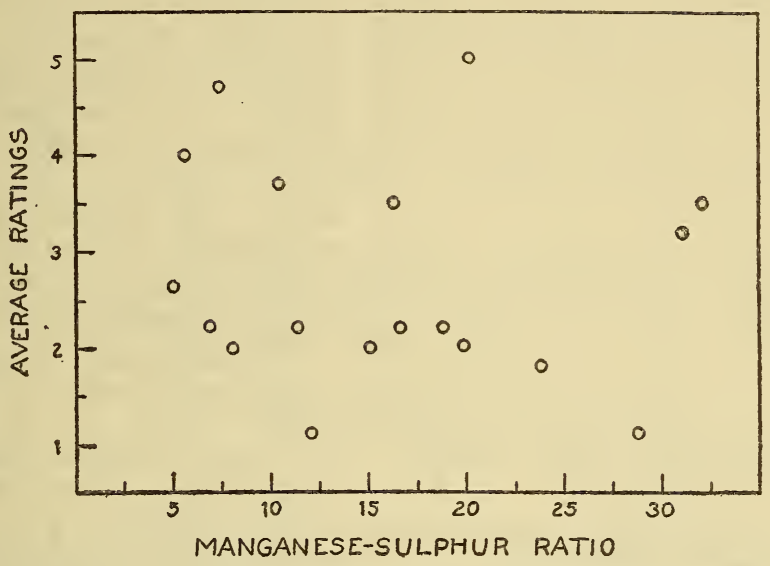

FIGURE 4.-Average ratings plotted against manganesesulphur ratios

the manganese-sulphur ratio and the combined carbon in Figures 4 and 5. From the data shown in Figure 4, it appears that control of the manganese-sulphur ratio offers little promise. Figure 6 indicates that phosphorus in itself is not a major factor, since both good and bad specimens are found whether the phosphorus is present in

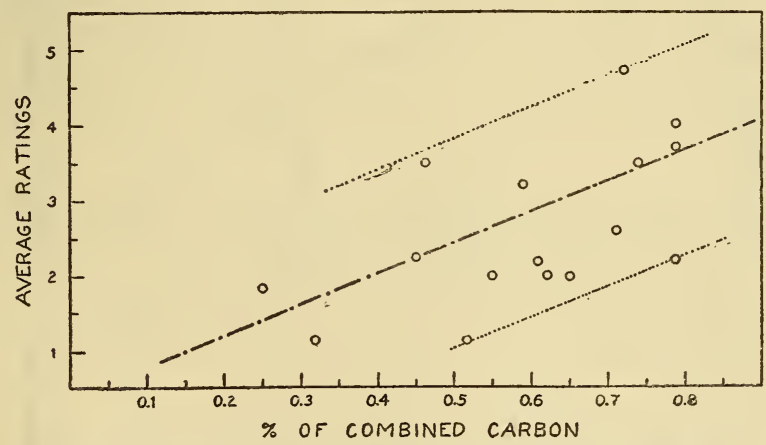

FIGURE 5.-Average ratings plotted against per cent of combined carbon

Heavy line indicates general trend and light lines indicate upper and lower limits.

amounts of 0.50 or 0.80 per cent. On the other hand, it does appear that as a general thing the lower the combined carbon, the less the tendency toward blistering, although in some cases high combined carbon does not appear to be detrimental. Figure 7 indicates that, other things being equal, the combined carbon falls as the silicon 
increases, as is to be expected; that is, there is some indication that the softer irons (low combined carbon, high silicon) give less trouble than the harder irons.

It should be pointed out that besides the variables plotted in these figures there are other variables, which are neglected in the figures.

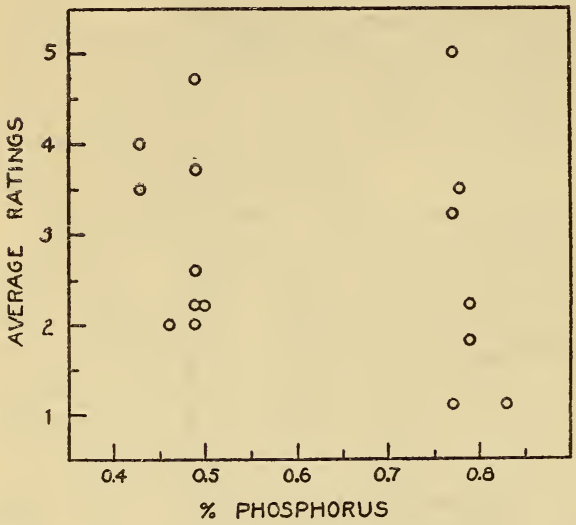

FIGURE 6.-Average ratings plotted against per cent of phosphorus

For instance, in Figure 6, the position of the points is influenced by the combined carbon content as truly as they are in Figure 5, but the combined carbon content is neglected in Figure 6. Hence, the figures should be considered only as approximate indications of the effect of individual elements upon blistering tendencies.

Various mold facings were tried, as shown in Table 7 . Heats $48,50,51,52$, and 53 , all with carbonaceous mold facings, ranged from 2.3 to 3.5 average rating. A proprietary mold facing was suggested as a possible cure for blisters. This facing was of complex composition and contained much carbonaceous material. When this was used on parts of molds, the corresponding parts of the castings, when enameled, were found to blister exces-

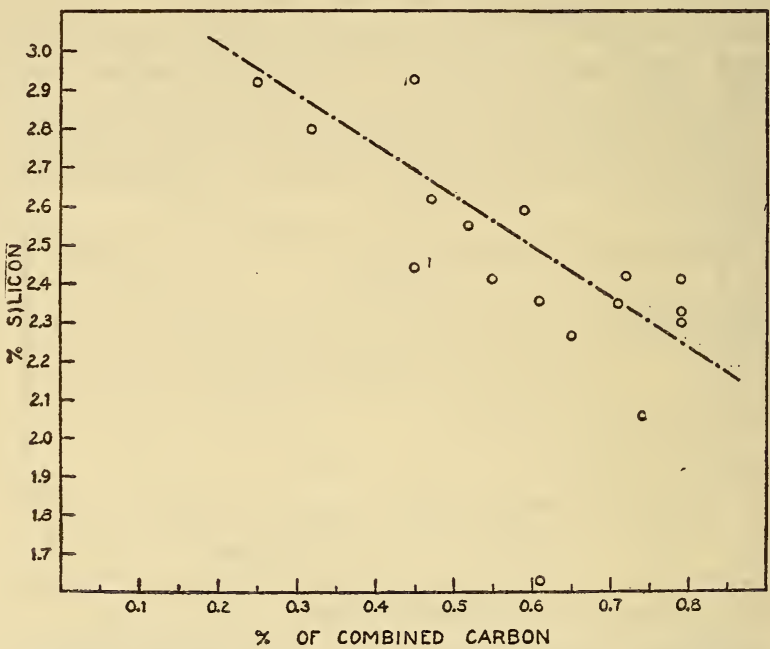

FIgURe 7.-Per cent of silicon plotted against per cent of combined carbon

sively, regardless of the iron used; whereas the parts that had been in contact with the uncoated mold blistered only slightly or not at all, depending on the iron. It may be pointed out, however, that a light application of plumbago seemed to be rather beneficial in the case of heat 51. 


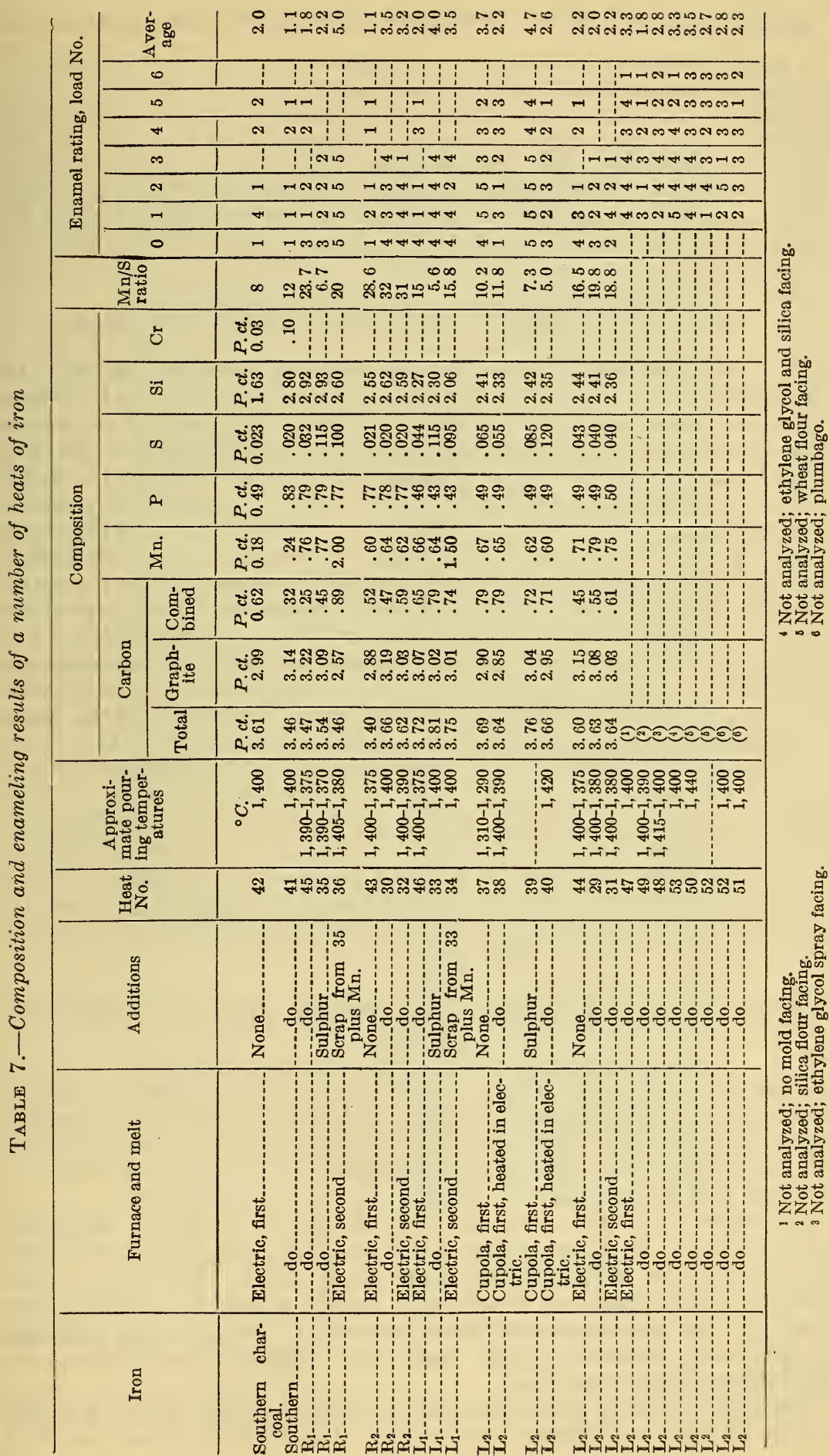




\section{NONBLISTERING IRON BECOMES BLISTERING ON REMELTING}

A need having arisen for more specimens of known "nonblistering" iron, some commercial castings which were left from the stock used in a study of enamels at the Bureau of Standards (4), and which were considered free from any tendency to blister, were remelted in the electric furnace and cast into standard test plates. On enameling these castings by the standard method they blistered badly. This again raised the question whether irregularities in results should be attributed to the iron or to some unconsidered variable in the enameling process.

\section{6. "BAKING" PROCESS AND WATER ADSORPTION TESTS}

The idea of preheating at a low temperature (termed "baking" to distinguish it from the "burning-out" process) was tried out. Since enamel is applied wet and contains uncalcined clay to hold it in suspension, it appeared possible that the water of constitution of the clay which would not be driven off in drying, might react during the firing process and be a cause of blisters. It was also considered possible that water might be firmly adsorbed in microscopic or submicroscopic "pores" of the metal, since an adsorption of moisture during pickling, which is not given off on drying but is given off at galvanizing temperatures, has been suggested by Lindemuth (9) as a possible cause for blistering of galvanized sheet. The details and effects of the baking treatment are discussed in one of the following sections.

In order to study the hypothesis that water adsorbed in pores might play a part, seven specimens each of the two irons, $R_{2}$ and $L_{2}$, were sand-blasted and then soaked in water 40 hours, after which they were wiped with a towel, sprayed with ground coat in the regular manner, and put through the "range" test. (See following section.) The results are shown in Figure 8, and should be compared with the lower halves of the specimens in Figure 9, which were not water-soaked. The weakly blistering iron, $R_{2}$, was not affected by the water-soaking treatment, but the strongly blistering iron, $\mathrm{L}_{2}$, appeared to be somewhat more blistered on the three and five minute ground-coat firings with water-soaking than without.

\section{THE RANGE METHOD OF FIRING AND ITS APPLICA- TIONS}

In the attempt to make the "standard" enameling process a sharper "indicator" so that a laboratory test would more clearly show whether a given metallurgical change in composition or treatment of the castiron had affected its blistering properties favorably or adversely, a new test was developed.

The basis of the new test was that each iron should be enameled under a variety of firing treatments instead of a single one, and that irons should be distinguished from each other according to the breadth of the range of treatments within which no blisters were observed. Seven specimens were required to make a test and, for the particular enamels which had been supplied the bureau, the following schedule was used:

The ground coat was fired at $875^{\circ} \mathrm{C}$. (about $1,605^{\circ} \mathrm{F}$.) for varying: lengths of time on different specimens. The first specimen was fired 


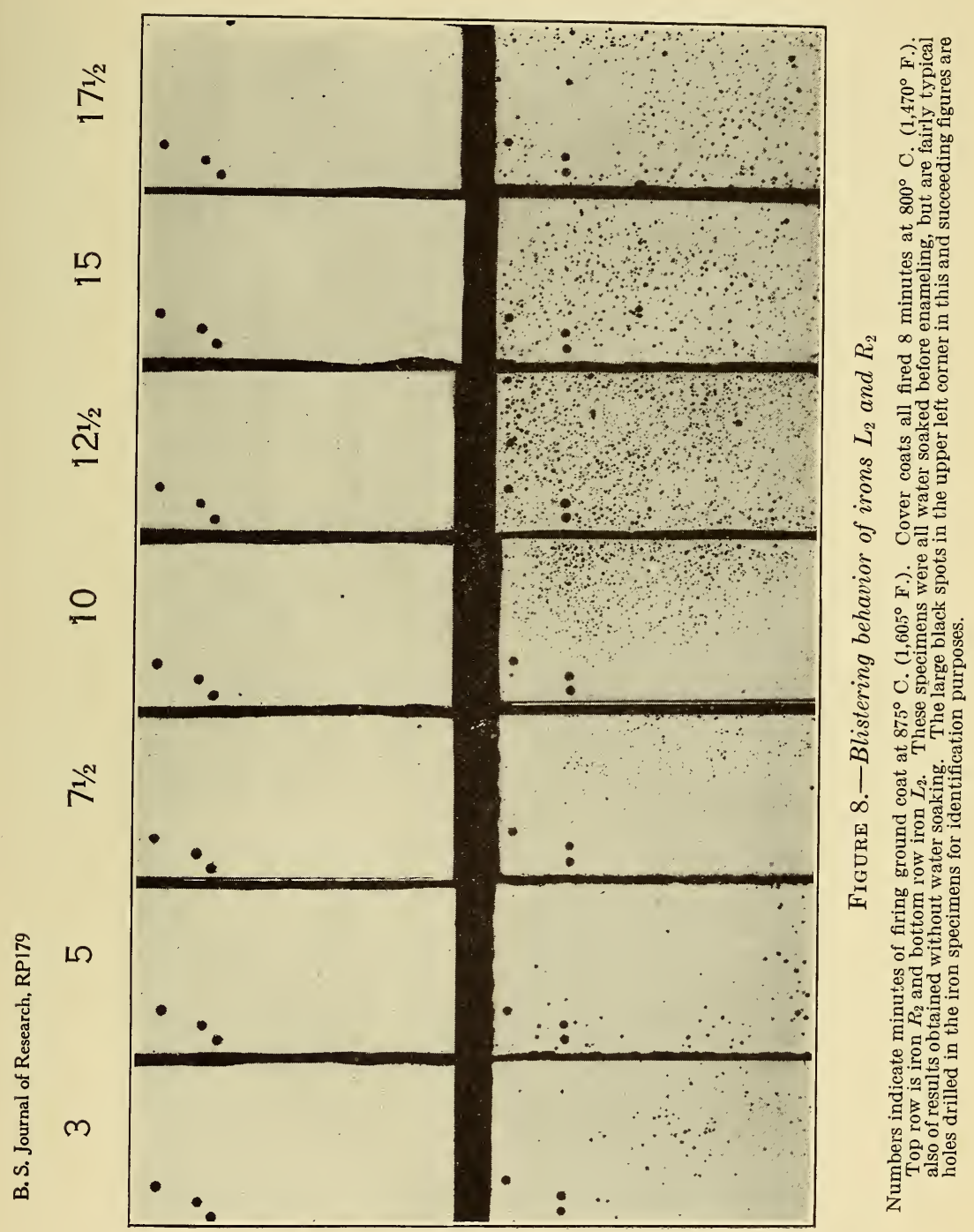




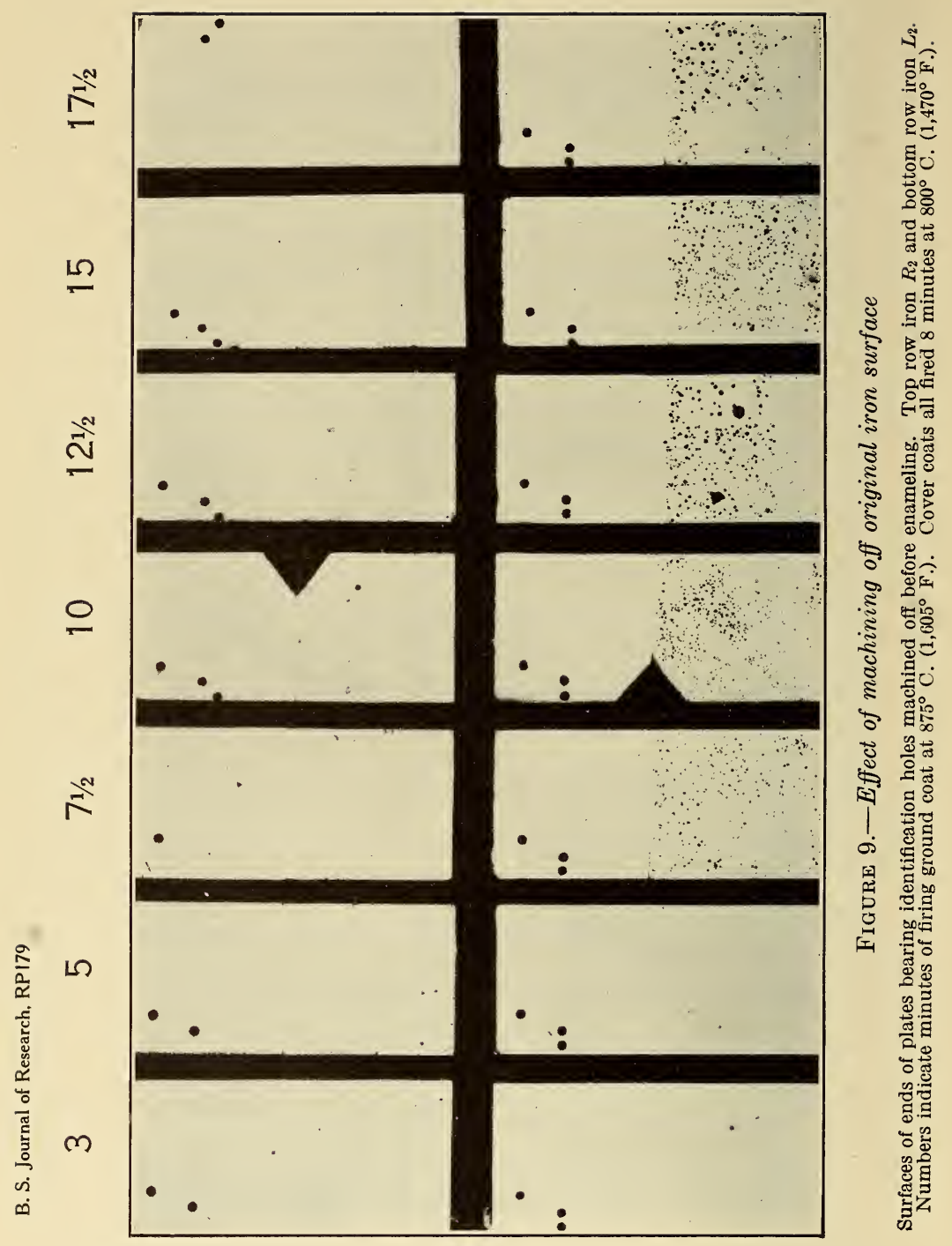


for 3 minutes, the second 5 minutes, the third $7 \frac{1}{2}$ minutes, and so on by $21 / 2$-minute increments, the seventh specimen being fired $17 \frac{1}{2}$ minutes. Then the cover coat was applied to all under uniform conditions and fired for 8 minutes at $800^{\circ} \mathrm{C}$. (about $1,470^{\circ} \mathrm{F}$.). Except for the firing periods, and the specification of 3.0 to $3.6 \mathrm{~g}$ of wet ground instead of 3.0 to $4.0 \mathrm{~g}$, the conditions of application as worked out in the standard process were retained.

Different lots of castings reacted to this test in various ways. One lot might give the best results when the ground coat was fired for five minutes and another when it was fired for seven and a half minutes, while a third would be almost free from blisters throughout the range of treatments. It then became apparent that no single-firing treatment could fairly be chosen as standard.

Looking at the bottom half of each of the two sets of comparison plates in Figure 9, one will note that, at five minutes' firing of the ground coat, the specimen in the bottom row would be called superior to that in the upper row, whereas at seven and a half minutes' firing, the opposite is very clearly shown. The whole series shows unmistakably that the upper row is the better.

Blistering may be considered as a gas-producing reaction between the metal and the enamel, or the air. This reaction requires time. A metal that can be heated over a wide range of firing periods without blistering is obviously better than one which is equally free from blistering at one definite condition of firing, but will blister if that condition is not adhered to.

A few check tests were made on specimens from heats of iron which had previously been enameled by the standard procedure. It was found that the check specimens gave quite different results when the ground coat was fired under different conditions. This observation may help to explain some of the erratic results of early tests both at the bureau and at the cooperating plants.

\section{FURTHER COOPERATIVE EXPERIMENTS}

\section{OUTLINE OF PROCEDURE}

After some preliminary tests, it was decided to submit the two irons, $R_{2}$ and $L_{2}$, to cooperative tests at the bureau and at two commercial laboratories. The specimens and the enamels were distributed from the bureau and the process of application which has been given in the description of the range test was used in these cooperative experiments. In addition, a high lead enamel without a ground coat was applied under the conditions which are given in Table 8. 
TABLE 8.-High lead enamel

[Applied as two coats, without ground coat]

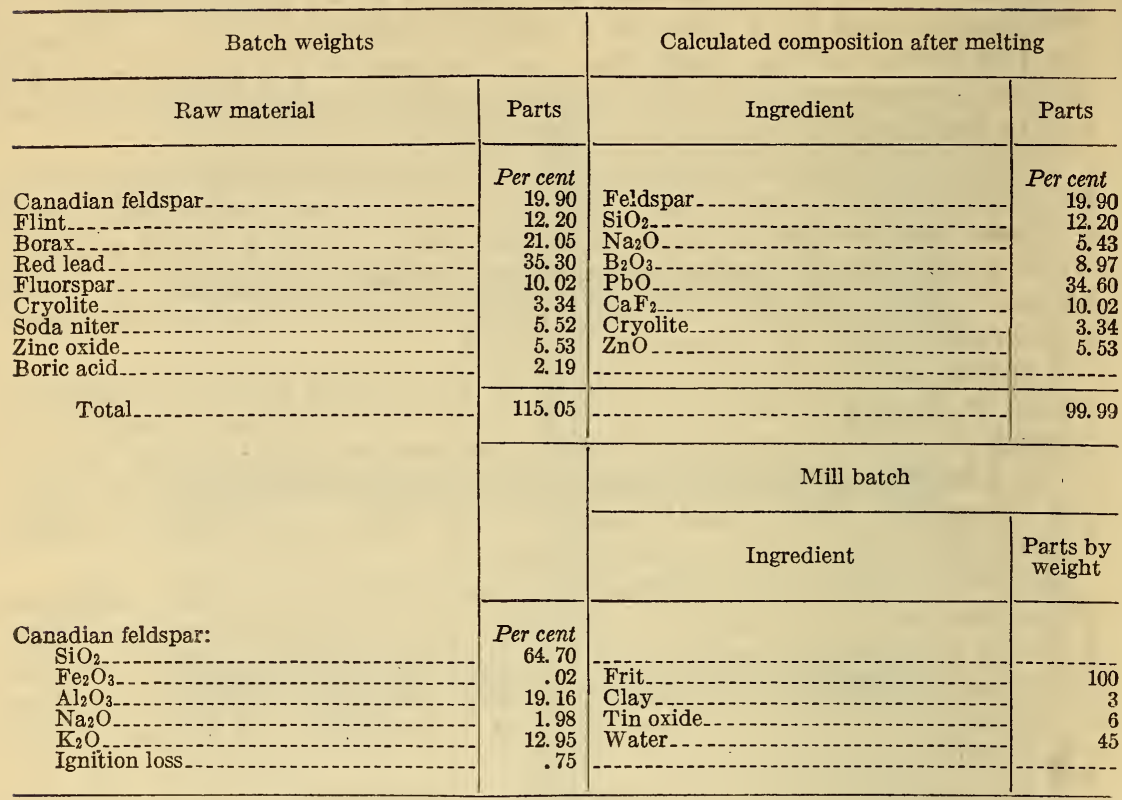

The slip (enamel suspension) was made up to a specific gravity of 2.15 and sprayed on the castings, the wet coating, weighing 6.0 to $6.6 \mathrm{~g}$ per specimen. After drying at not less than $90^{\circ} \mathrm{C}$. $\left(195^{\circ} \mathrm{F}\right.$.) for not less than an hour the plates were fired at $710^{\circ} \mathrm{C} .\left(1,310^{\circ} \mathrm{F}\right.$.). The temperature of the furnace regained its original value in five minutes after insertion of the load. Seven sets were fired, the initial firing period being 10 minutes, which was increased by $2 \frac{1}{2}$-minute increments up to 25 minutes for successive firings. The second coat (20 to $22 \mathrm{~g}$ per specimen) was sprayed on, dried as before, and fired at $660^{\circ} \mathrm{C} .\left(1,220^{\circ} \mathrm{F}\right.$.) for 12 minutes.

In these cooperative experiments some tests of the baking treatment mentioned above were included. In one set of tests the baking was done on the ground coat only, in another both ground and cover coats were baked, and in the third only the cover coat. Baking was always carried out in a furnace at $500^{\circ} \mathrm{C}$. $\left(930^{\circ} \mathrm{F}\right.$.) for a period of eight minutes and the ground coats were all fired in seven and one half minutes. For these tests, including those on baking, four electric furnace heats of the two irons, $R_{2}$ and $L_{2}$, were made, a total of 1,440 specimens being prepared.

\section{RESULTS OBTAINED}

The results of these tests and the chemical compositions of the irons, are given in Tables 9 and 10, respectively. 


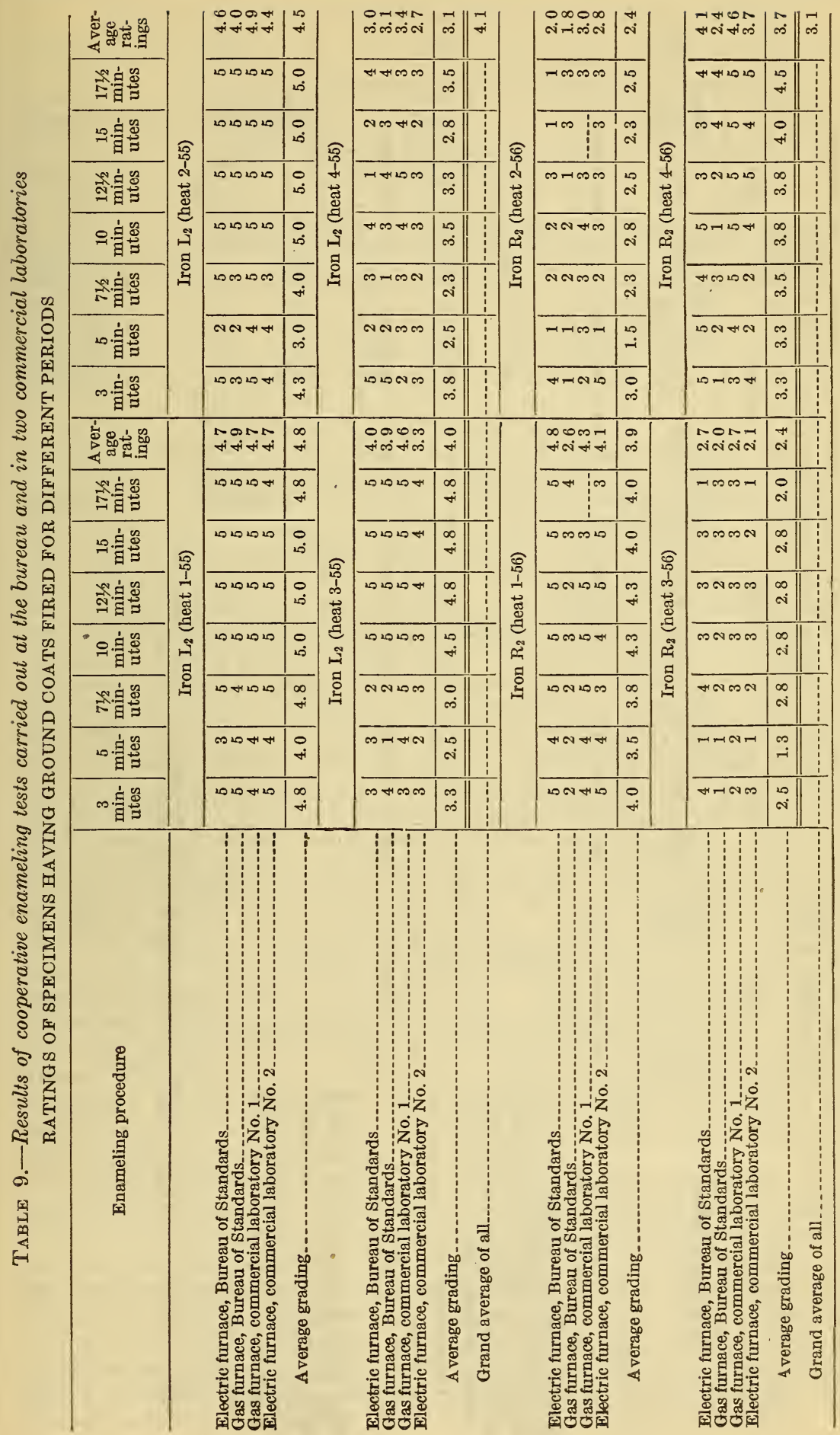




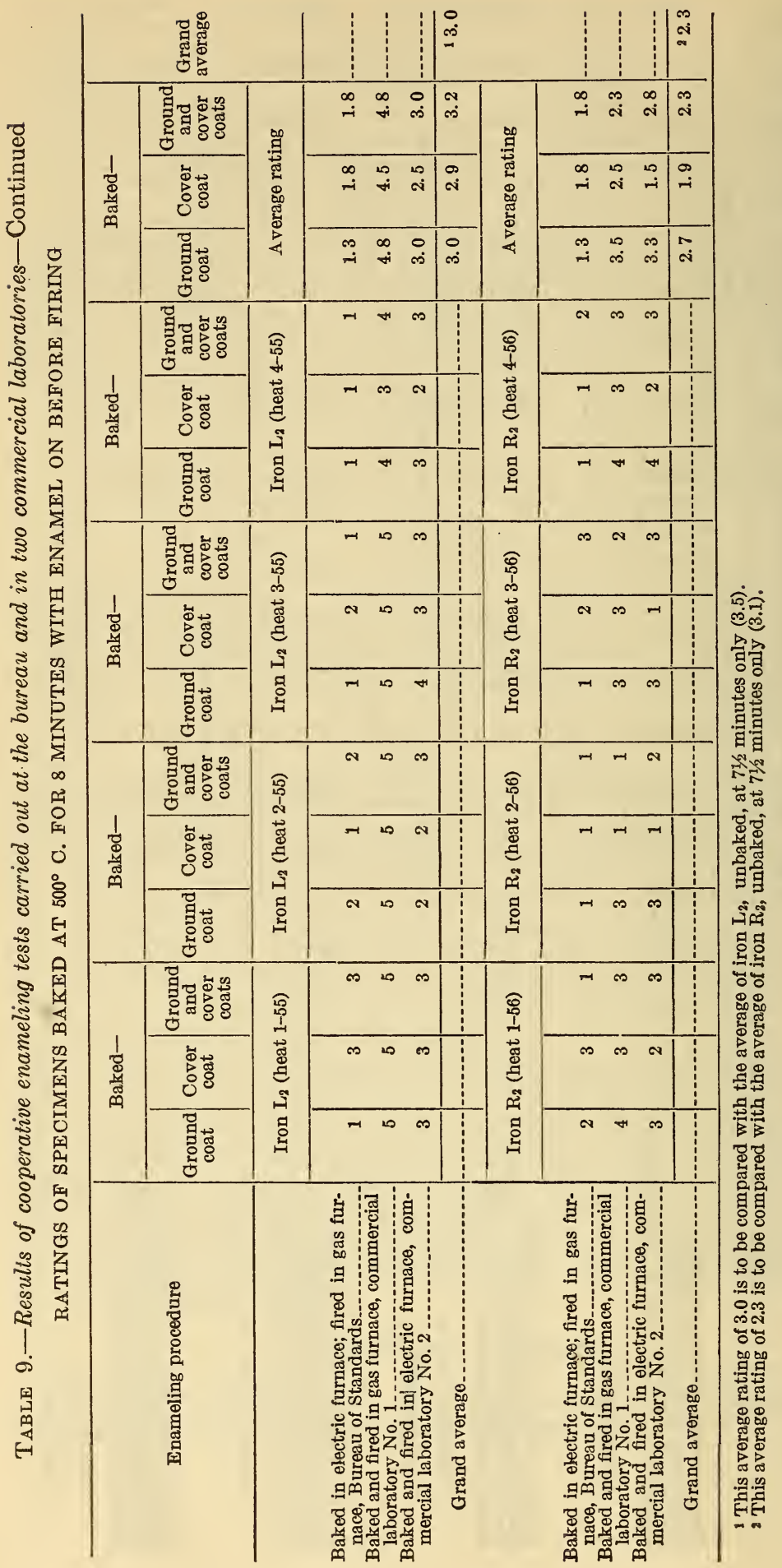


TABLE 10.-Results of analyses of different heats of irons $L_{2}$ and $R_{2}$

\begin{tabular}{|c|c|c|c|c|c|c|c|c|c|c|}
\hline \multirow{3}{*}{$\begin{array}{l}\text { Heat } \\
\text { No. }\end{array}$} & \multirow{3}{*}{ Iroṇ } & \multirow{3}{*}{$\begin{array}{l}\text { Approxi- } \\
\text { mate pour- } \\
\text { ing tempera- } \\
\text { tures }\end{array}$} & \multicolumn{8}{|c|}{ Composition } \\
\hline & & & \multicolumn{3}{|c|}{ Carbon } & \multirow{2}{*}{$\mathrm{Mn}$} & \multirow{2}{*}{$\mathrm{P}$} & \multirow{2}{*}{$\mathrm{S}$} & \multirow{2}{*}{$\mathrm{Si}$} & \multirow{2}{*}{$\mathrm{Cr}$} \\
\hline & & & Total & $\begin{array}{l}\text { Gra- } \\
\text { phite }\end{array}$ & $\begin{array}{l}\text { Com- } \\
\text { bined }\end{array}$ & & & & & \\
\hline $\begin{array}{l}1-55 \\
2-55 \\
3-55 \\
4-55\end{array}$ & 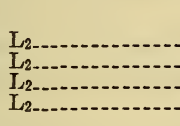 & $\begin{array}{r}{ }^{\circ} C . \\
1,410-1,388 \\
1,380 \\
1,390 \\
1,400\end{array}$ & \begin{tabular}{|c} 
Per cent \\
3.40 \\
3.54 \\
3.46 \\
3.36
\end{tabular} & $\begin{array}{c}\text { Per cent } \\
2.93 \\
3.06 \\
2.94 \\
3.10\end{array}$ & $\begin{array}{c}\text { Per cent } \\
0.47 \\
.48 \\
.52 \\
.26\end{array}$ & \begin{tabular}{c} 
Per cent \\
.0 .72 \\
\hdashline .72
\end{tabular} & $\begin{array}{c}\text { Per cent } \\
0.555 \\
.515\end{array}$ & $\begin{array}{c}\text { Per cent } \\
0.035\end{array}$ & $\begin{array}{c}\text { Per cent } \\
2.37 \\
2.34 \\
2.39 \\
2.30\end{array}$ & $\begin{array}{r}\text { Per cent } \\
0.04 \\
\hdashline .04\end{array}$ \\
\hline $\begin{array}{l}1-56 \\
2-56 \\
3-56 \\
4-56\end{array}$ & $\begin{array}{l}R_{2} \ldots \\
R_{2} \ldots \\
R_{2} \ldots \\
R_{2} \ldots\end{array}$ & $\begin{array}{r}1,398 \\
1,398 \\
1,388 \\
1,380-1,350\end{array}$ & $\begin{array}{l}3.13 \\
\text { 3. } 48 \\
3.39 \\
3.45\end{array}$ & $\begin{array}{l}2.94 \\
\text { 3. } 10 \\
3.11\end{array}$ & $\begin{array}{l}.19 \\
.38 \\
.28 \\
27\end{array}$ & .61 & .790 & .027 & $\begin{array}{l}2.53 \\
2.22 \\
2.51 \\
2.45\end{array}$ & .03 \\
\hline & & $1,380-1,350$ & 3.45 & 3. 08 & & & & & & .04 \\
\hline
\end{tabular}

Two factors which are very important stand out clearly from the results of these cooperative tests. First, there is a difference in the tendencies of different lots of iron to produce blisters when enameled under uniform conditions. Second, different heats of the same pig iron may vary in their blistering tendencies just as definitely as heats from different pig irons do. Table 9 shows that there are four heats of each iron and four sets of testing conditions for each heat (two commercial laboratories and two different types of furnaces at the bureau). The average ratings under these four sets of conditions agreed very well in placing the different sets of castings in order of blistering tendency. Thus, for the four heats of iron $\mathrm{L}_{2}$, heat 4-55 was first (in order of increasing blistering tendency) in all four cases. Heat $3-55$ was second in all four cases. Heat $2-55$ was third in three out of four cases, and fourth in the remaining case. Heat 1-55 was at the bottom of the list (greatest blistering tendency) in three out of four cases, and next to the bottom in the other one case. For iron $R_{2}$ there was unanimous agreement that heats $2-56$ and 3-56 are both better than either 1-56 or 4-56. The former two heats were evenly divided between first and second places. Heat 4-56 received third place in three out of four cases, and fourth place in the remaining case. Heat 1-56 received the lowest rating in three out of four cases, and next to the lowest in the other case. The average ratings (Table 9 ) showed that heat $4-55$ has so much less blistering tendency than the other three heats of iron $\mathrm{L}_{2}$ that it may be classed separately from them. Likewise, heat $1-56$ has considerably more blistering tendency on the average than the other three heats of iron $R_{2}$. The superiority of iron $R_{2}$ over $L_{2}$, with respect to blistering tendency, is quite marked in the remaining six heats.

Commercial laboratory No. 2 as a rule produced specimens not so badly blistered as laboratory No. 1. In this connection it is significant (in view of the results reported later) that laboratory No. 2 used a commercial sand-blasting outfit with 90 pounds air pressure (firing in an electric furnace) while laboratory No. 1 used a laboratory sand blast at a considerably lower air pressure (firing in a gas furnace).

The data discussed above all apply to the process and enameis adopted as standard. Practically no information was gained from the low fusion, high lead enamel test, for very little difference was shown between the different lots of castings with this enamel. 
The results obtained with the baking tests varied according to the laboratory in which the tests were made. Since in the baking tests the ground coats were all fired seven and one-half minutes $\left(875^{\circ} \mathrm{C}\right.$., about $1,605^{\circ} \mathrm{F}$.), it seems logical to compare the baked specimens with only those unbaked ones which had the same firing treatment. The data in Table 9, when analyzed in this way, show that in the bureau tests baking was distinctly beneficial, and that baking of the ground coat only caused greater improvement than any other baking procedure.

The results of some additional tests on baking which were carried out at the bureau, but not duplicated in the two cooperating laboratories, are given in Table 11.

TABLE 11.-Results of enameling tests on heat No. 44 , iron $L_{2}$ after baking

[Ratings of specimens having ground coats fired for different periods]

\begin{tabular}{|c|c|c|c|c|c|}
\hline & $\begin{array}{l}3 \text { min- } \\
\text { utes }\end{array}$ & $\begin{array}{l}5 \text { min- } \\
\text { utes }\end{array}$ & $\begin{array}{l}71 / 2 \min - \\
\text { utes }\end{array}$ & $\begin{array}{l}10 \text { min- } \\
\text { utes }\end{array}$ & $\begin{array}{l}12 \frac{1}{2} \min - \\
\text { utes }\end{array}$ \\
\hline $\begin{array}{l}\text { Ground coat and cover coat baked } 8 \text { minutes at } 500^{\circ} \\
\text { C. }\left(930^{\circ} \text { F.) }\right.\end{array}$ & $\begin{array}{l}3 \\
3\end{array}$ & $\begin{array}{r}3 \\
4 \\
13\end{array}$ & $\begin{array}{l}2 \\
4\end{array}$ & $\begin{array}{l}3 \\
4\end{array}$ & $\stackrel{3}{2}$ \\
\hline A verage & & 27 & & 35 & \\
\hline Not baked.....-.. & $\begin{array}{l}5 \\
5\end{array}$ & $\begin{array}{r}4 \\
4 \\
12\end{array}$ & $\begin{array}{l}3 \\
4\end{array}$ & $\begin{array}{l}4 \\
5\end{array}$ & $\begin{array}{l}4 \\
5\end{array}$ \\
\hline & & & & & \\
\hline A verage & 5 & 3.5 & 3.5 & 4. 5 & 4.5 \\
\hline
\end{tabular}

1 Duplicate.

The results of the above-tabulated baking tests and the tests of all three laboratories considered as a whole, indicate that baking is helpful under some conditions, and if properly worked out in any particular case would doubtless constitute an added factor of safety, but that this treatment can not be relied upon to eliminate blistering.

\section{EFFECT OF THE SURFACE LAYERS OF CASTINGS ON THEIR ENAMELING PROPERTIES}

\section{IMPORTANCE OF CLEANING OPERATION}

From microscopic data on hand at an early stage of the investigation, it was suspected that the source of trouble might be located in the surface layer and that the removal of this would eliminate blistering. A systematic investigation was not carried out at that time, because of the negative results which were obtained with some of the specimens, the surface of which had been machined and sandblasted before enameling.

The importance of the cleaning operation was again brought up and given serious consideration on account of more recent observations showing that prolonged sand-blasting resulted in a noticeable improvement, although the normally cleaned specimens showed no indication of improper sand-blasting. This question of the proper cleaning of cast-iron ware to be enameled has been very strongly emphasized in recent literature (5). In this connection it may be 
noted that variations in air pressure, reuse of old sand with large proportions of material too fine to produce effective cleaning, and changes in amount and velocity of sand due to wear of the sand-blast nozzle may pass unnoticed, so that equal removal of the surface of the castings during sand-blasting may not be obtained with equal time of blasting. Similarly if a skin of burned-on molding sand is present, the early period of the sand-blasting process will be occupied in removing the sintered sand rather than in cleaning the surface of the iron itself.

\section{SURFACE REMOVAL ELIMINATES BLISTERS}

Experiments were made in which the surface of each casting was machined off across one end, the other end receiving only the regular sand-blasting. Specimens prepared in this way were given the range of firing treatments which has been described. Specimens from one of the better heats of iron $R_{2}$ and of the blistering heats of iron $L_{2}$ were used. The unmachined ends of the specimens showed the usual result, namely, that iron $R_{2}$ gave very few blisters under any of the treatments, whereas iron $L_{2}$ blistered throughout the greater part of the range. (Fig. 9.) On the other hand, the machined ends of both sets of castings were relatively free from blisters throughout the range of treatments, even when the ground coat firing period was as long as $17 \frac{1}{2}$ minutes. Out of 37 tests, with this firing period, on unmachined specimens of irons $R_{2}$ and $L_{2}$, only three specimens had been given ratings better than 3 . It was found also in a limited number of tests that the pickling of normally sand-blasted specimens with 12 per cent hydrochloric acid for 10 minutes at $60^{\circ} \mathrm{C}$. $\left(140^{\circ} \mathrm{F}\right.$.) was almost, if not quite, as effective in eliminating blisters from iron $\mathrm{L}_{2}$ as the machining. Thus, prolonged sand-blasting, pickling, and machining removed the surfaces of the castings, and in doing so removed the source of blistering. ${ }^{2}$

Since each of the treatments mentioned above lightened to some extent the treated portions of the castings and caused a more rapid rise in temperature when placed in the furnace, the following experiments were made to determine whether or not the improvement of the treated ends of the castings was related to this condition.

A set of castings was planed off at one end on the opposite side from that enameled and given the regular range of enameling treatments. In this case the thin ends of the castings were no better than the thick ends, a result which indicated that the improvement above can not be attributed to the effect of decreased thickness of the castings upon the rate of heat absorption.

In order to get an idea how deep this "blistering" layer extends, specimens of iron $L_{2}$, after normal sand-blasting (which did not remove all the "blistering" layer) were machined at a slight angle to the surface to be enameled. Since the plates were not perfectly flat, the machined areas were somewhat irregular in shape. Figure 10 shows how the removal of an extremely thin layer sufficed to remove

2 After publication of this statement in a progress report (J. Am. Cer. Soc., 11, No. 8; August, 1928), information was received from several sources that some blistering irons were encountered in regular production which were not improved by removal of the surface layer. These reports were not received in time to do any investigative work of which the results could be included in the present paper. If blistering was due in these cases to defects such as sponginess in the castings, marked improvement would not be expected from removal of the surface layer. 
the material responsible for blistering. It will be noted that blistering disappeared entirely at the boundary of the machined surface.

Whereas previous study had been directed primarily at the chemical composition and physical soundness, the work was now concentrated on the surface layers of the castings.

A more carefully controlled sand-blasting procedure was used in the subsequent work, to minimize any irregularities in results arising from variations in sand-blast treatment. Ottawa silica sand (20 to 30 mesh) was delivered at 60 pounds pressure, from a nozzle of 1 inch inside diameter, normal to the surface of the specimens placed 4 inches below for a period of 45 seconds. The specimens were moved horizontally during sand-blasting, and when an occasional specimen having less than the usual 18 square inch surface was blasted, a proportionally shorter period of blasting was used.

\section{ADDITIONS OF SOFTENING AGENTS, ALSO PHOSPHOROUS AND FUSED SODIUM CARBONATE}

On the theory that a softer (lower combined carbon) iron might be less "blistering" and more susceptible to removal of the surface layer in an ordinary cleaning process, an attempt was made to improve iron $\mathrm{L}_{2}$, the more strongly blistering one, by softening it. Since an increase in the silicon or nickel contents would tend to produce this result, one-half per cent of each element was added separately and the "range" method applied. (See Table 12.)

TABLE 12.-Effects of nickel and silicon additions on ratings of iron $L_{2}$ (electric furnace melts)

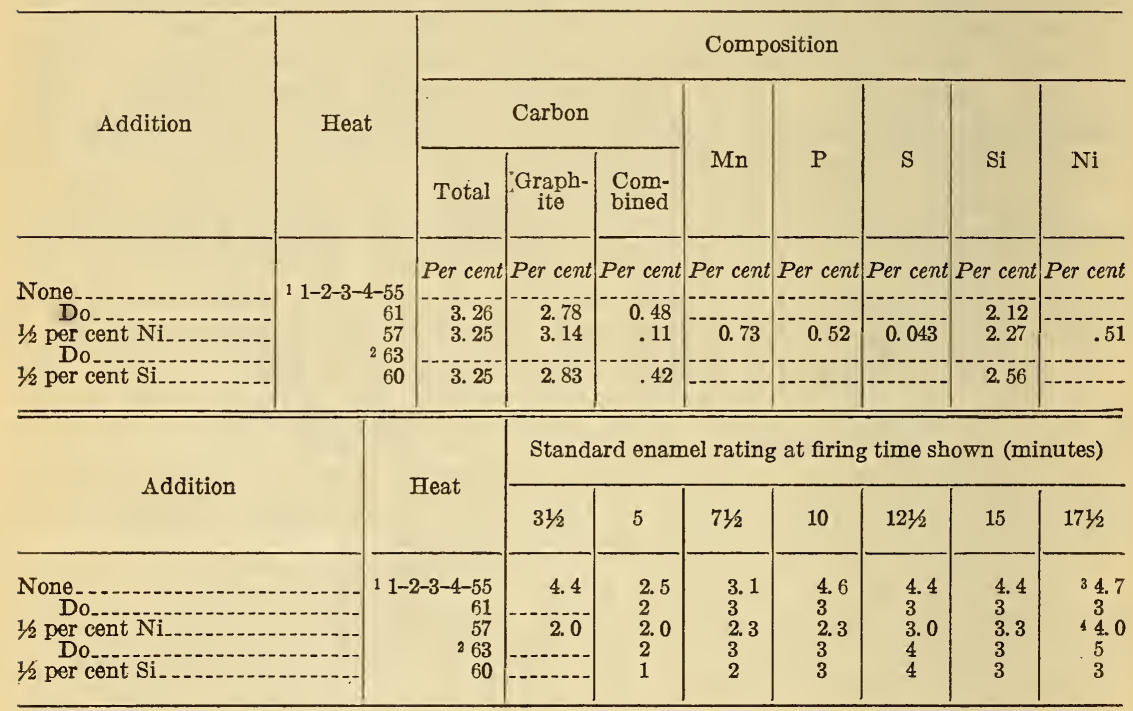

See Table 10.

Not analyzed.

Average of Bureau of Standards tests in Table 9 fur all four heats, without baking.

A verage of three sets of tests at bureau.

The results, compared with those of Table 9 over the important firing range of 5 to 10 minutes, appear promising since none of the softened irons were rated lower than grade 3 over this range, while in Table 9 half of the $L_{2}$ specimens tested at the bureau over this 
B. S. Journal of Research, RP179

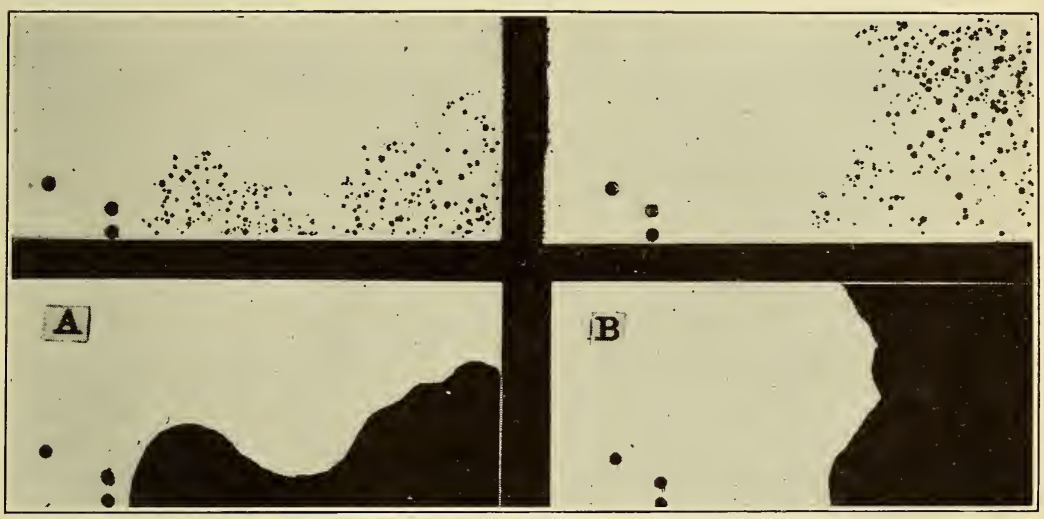

FIgURE 10.-Plates machined off at slight angle before enameling. Iron $L_{2}$, melts $2-55$ and 3-55

Lettered plates are graphical representations of appearance of plates after machining. Unshaded portions were machined; shaded portions had normal sand-blasted surfaces. Ground coat fired 10 minutes at $875^{\circ} \mathrm{C} .\left(1,605^{\circ} \mathrm{F}\right.$.) and cover coat 8 minutes at $800^{\circ} \mathrm{C} .\left(1,470^{\circ} \mathrm{F}\right.$.). 


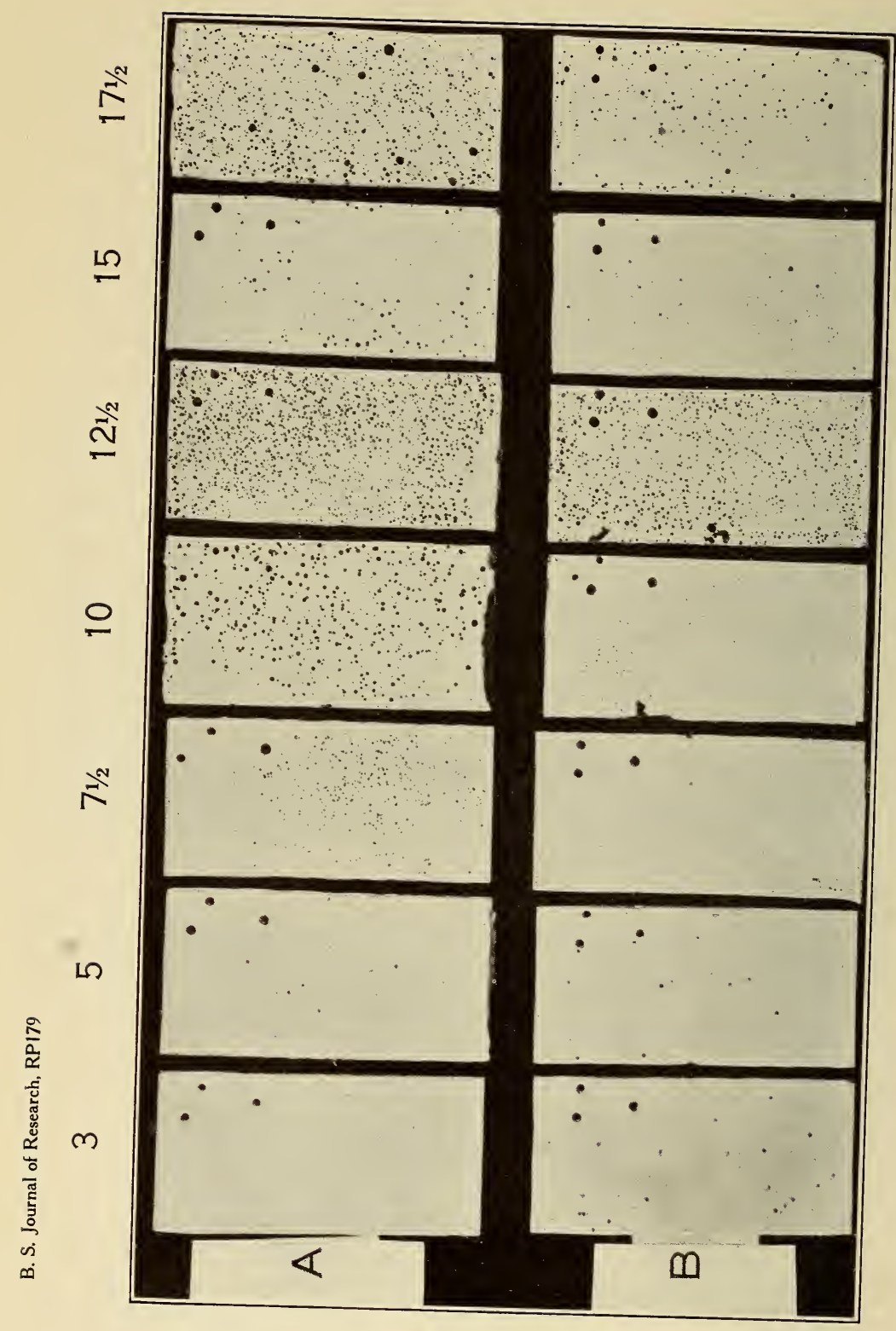




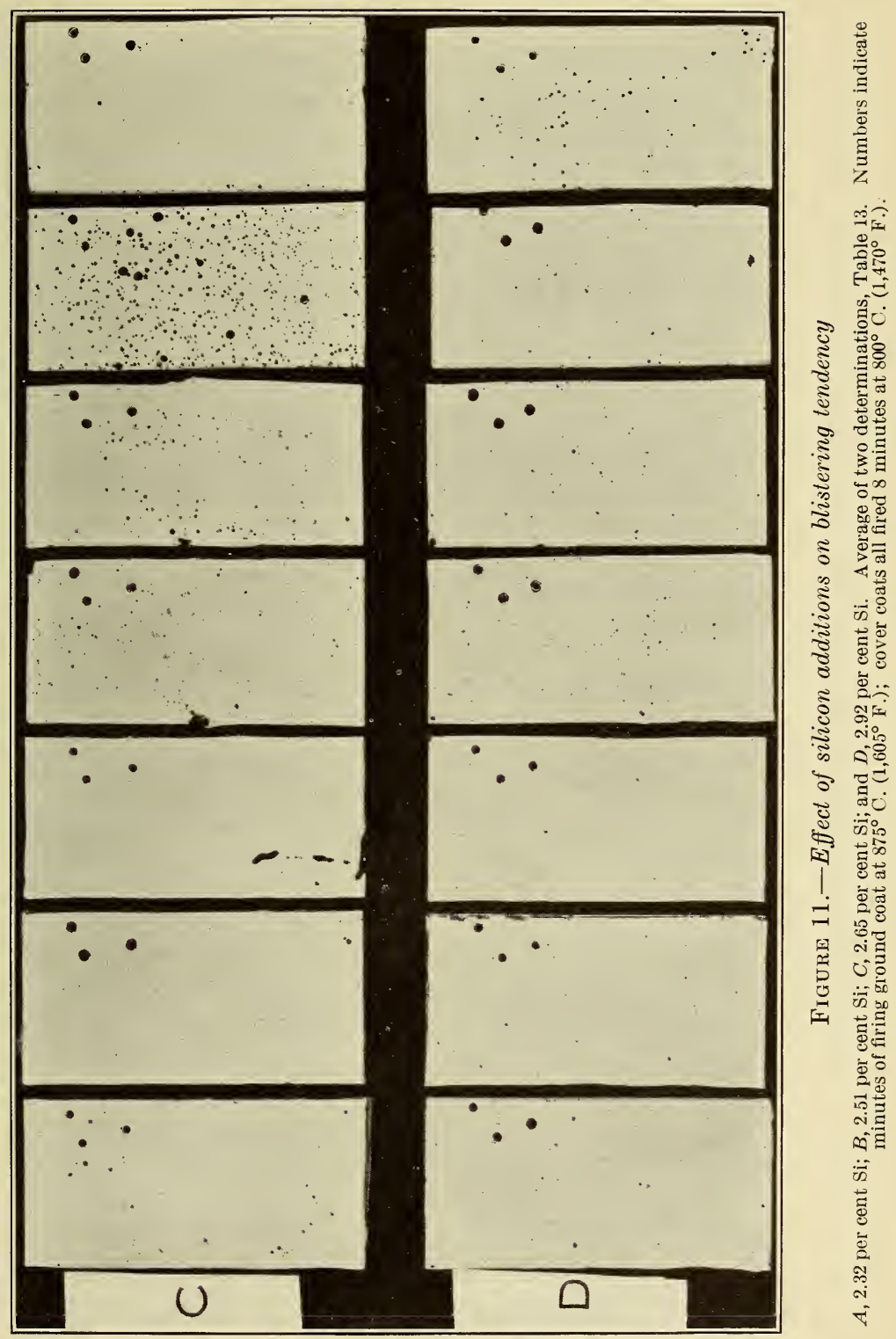




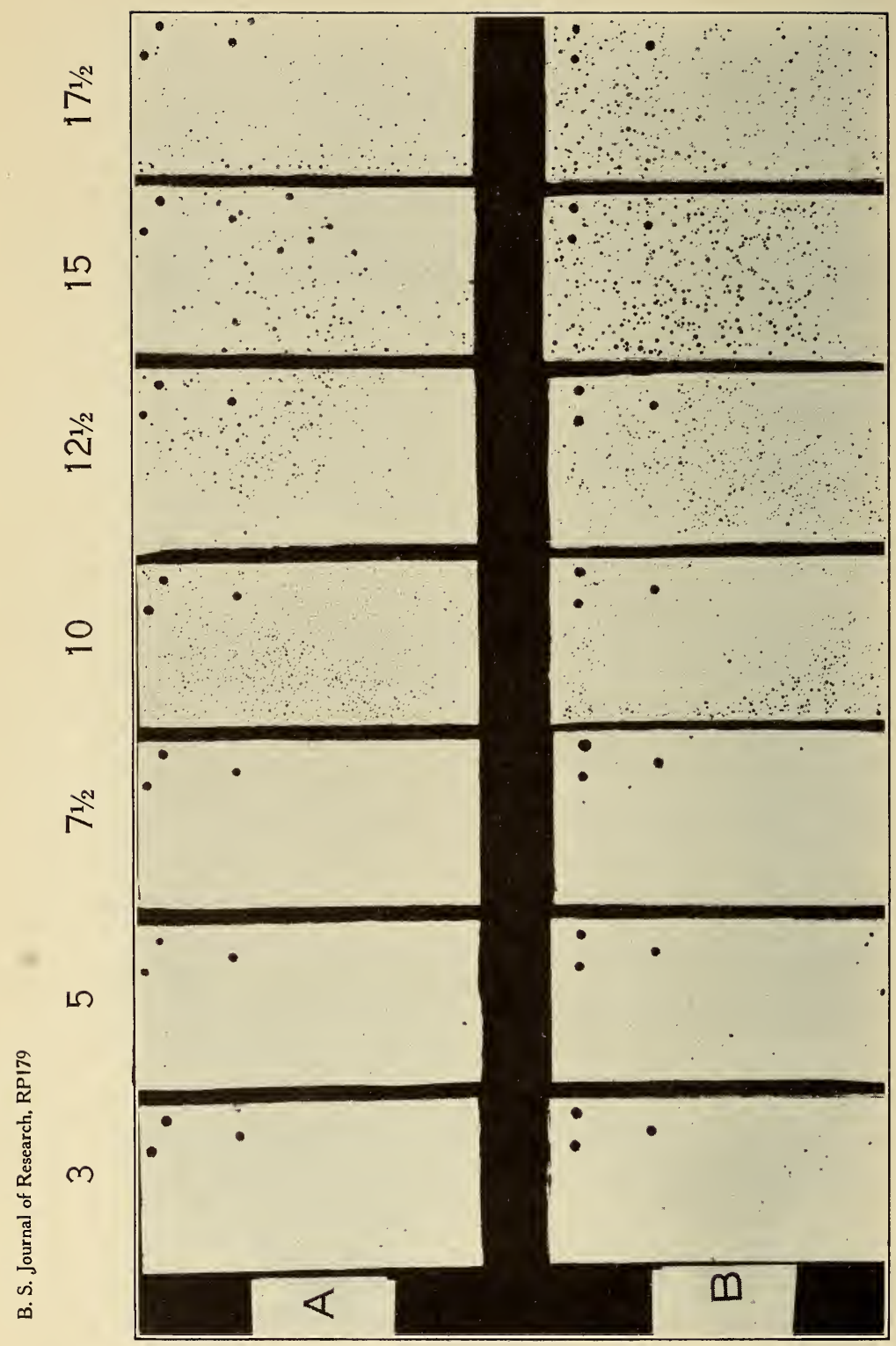




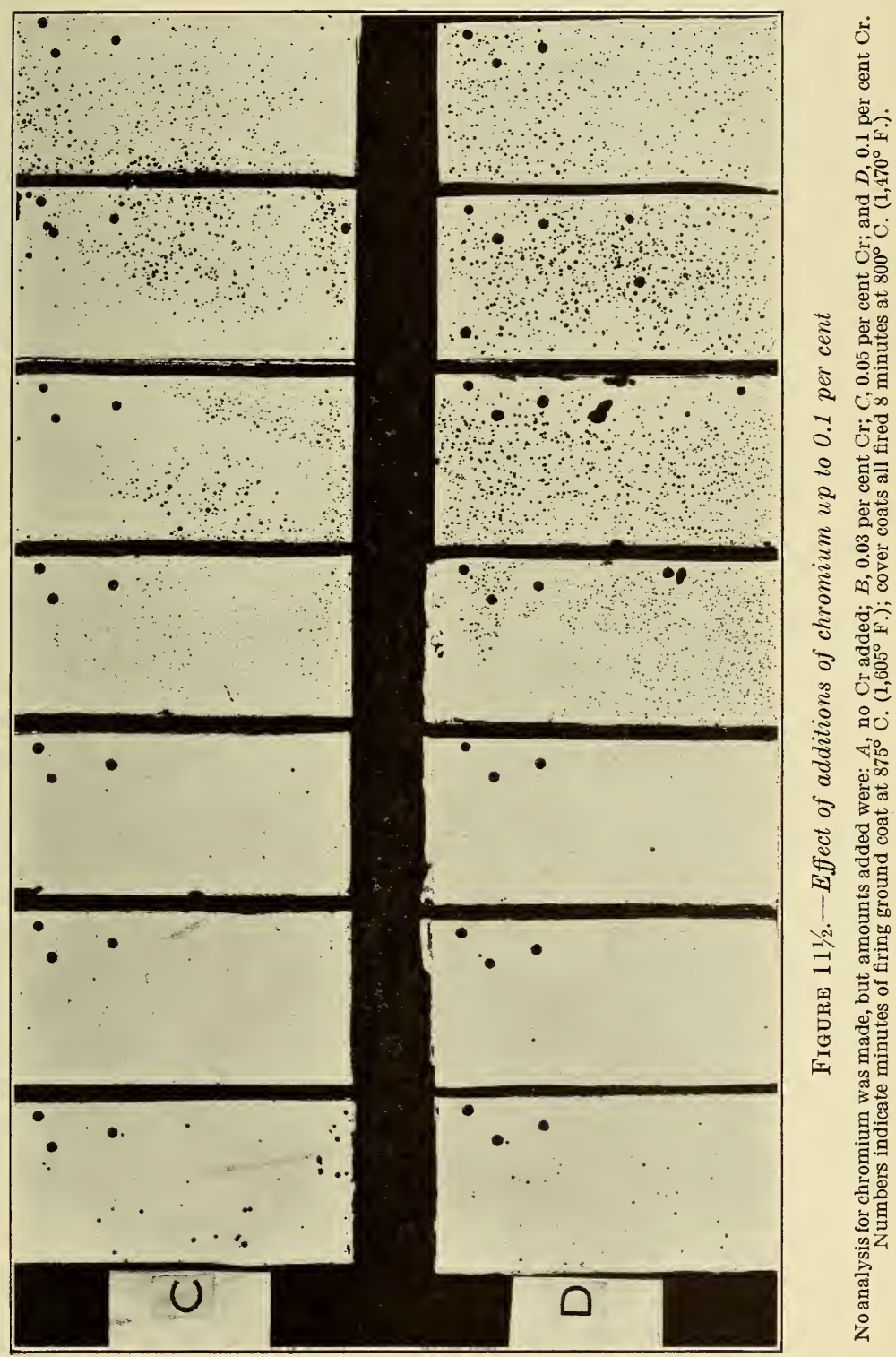


firing range were given poorer grades. However, in the həat of $\mathrm{L}_{2}$ (No. 61), used for comparison with this series, no specimens were rated worse than grade 3 , so the evidence was again inconclusive. Therefore, several further tests with additions of nickel, silicon, and aluminum were made. While no conclusive results were obtained in a limited number of experiments with ladle additions of one-half per cent and 2 per cent nickel, nor with 1 per cent aluminum, promising results were obtained with silicon additions made in the furnace. Table 13 and Figure 11 show that there was a noticeable improvement in the enameling properties of the blistering iron $L_{2}$ with a higher silicon content, addition of this element being made in the furnace. While the variation in silicon content was evidently not sufficient to cause a marked change in the average amount of combined carbon throughout the cross section of the castings, it is thought that this variation was large enough to affect the combined carbon in the surface layer. The phosphorus, as well as the silicon, contents of the strongly blistering iron, $\mathrm{L}_{2}$, were increased in certain heats to correspond with the weakly blistering iron, $R_{2}$. Also a few tests were carried out using fused sodium carbonate as a fluxing addition, but the results of these experiments did not indicate any marked improvement.

TABLE 13.-Tests of iron $L_{2}$ with and without additions of silicon (electric furnace melts)

\begin{tabular}{|c|c|c|c|c|c|c|c|c|c|c|c|c|c|c|}
\hline \multirow{3}{*}{$\begin{array}{l}\text { Plate } \\
\text { No. }\end{array}$} & \multirow{3}{*}{ Iron } & \multirow{3}{*}{$\begin{array}{c}\text { Approxi- } \\
\text { mate } \\
\text { pouring } \\
\text { tempera- } \\
\text { ture }\end{array}$} & \multicolumn{4}{|c|}{ Composition } & \multicolumn{8}{|c|}{$\begin{array}{l}\text { Standard enamel ratings at firing } \\
\text { periods shown in minutes }\end{array}$} \\
\hline & & & \multicolumn{3}{|c|}{ Carbon } & \multirow[b]{2}{*}{$\mathrm{Si}{ }^{1}$} & \multirow[b]{2}{*}{$31 / 2$} & \multirow[b]{2}{*}{5} & \multirow[b]{2}{*}{$71 / 2$} & \multirow[b]{2}{*}{10} & \multirow[b]{2}{*}{$12 \frac{1}{2}$} & \multirow[b]{2}{*}{15} & \multirow[b]{2}{*}{$171 / 2$} & \multirow[b]{2}{*}{$\begin{array}{l}\text { A.ver- } \\
\text { age }\end{array}$} \\
\hline & & & Total & $\underset{\text { ite }}{\text { Graph- }}$ & $\begin{array}{l}\text { Com- } \\
\text { bined }\end{array}$ & & & & & & & & & \\
\hline $1-73$ & $L_{2} \ldots$ & $\begin{array}{l}{ }^{\circ} C . \\
1,400\end{array}$ & $\begin{array}{l}\text { Per } \\
\text { cent } \\
\left\{\begin{array}{l}3.54 \\
3.52\end{array}\right.\end{array}$ & $\begin{array}{l}\text { Per } \\
\text { cent } \\
2.94 \\
3.05\end{array}$ & $\begin{array}{l}\text { Per } \\
\text { cent } \\
0.60 \\
.47\end{array}$ & $\begin{array}{l}\text { Per } \\
\text { cent } \\
2.35 \\
2.30\end{array}$ & $21 / 2$ & 2 & 4 & 5 & 4 & 4 & 5 & 3.8 \\
\hline $2-73$ & .... do do & 1,230 & & & & & 1 & $21 / 2$ & 4 & 5 & 5 & $41 / 2$ & 5 & 3.9 \\
\hline $3-73$ & $\mathrm{~L}_{2}+1 / 2$ per cent $\mathrm{Si}$ & 1,400 & $\left\{\begin{array}{l}3.54 \\
3.53\end{array}\right.$ & $\begin{array}{l}3.11 \\
3.20\end{array}$ & .43 & $\begin{array}{l}2.49 \\
2.53\end{array}$ & \} & $21 / 2$ & $31 / 2$ & 4 & 5 & 4 & 5 & 3.9 \\
\hline $4-73$ & $\mathrm{~L}_{2}+344$ per cent $\mathrm{Si}$ & 1,400 & $\left\{\begin{array}{l}3.41 \\
3.49\end{array}\right.$ & $\begin{array}{l}3.01 \\
3.01\end{array}$ & $\begin{array}{l}.40 \\
.48\end{array}$ & $\begin{array}{l}2.64 \\
2.65\end{array}$ & $31 / 2$ & 2 & 2 & $31 / 2$ & 4 & 5 & 3 & 3.3 \\
\hline $5-73$ & $\mathrm{~L}_{2}+1$ per cent $\mathrm{Si}$ & 1,400 & $\left\{\begin{array}{l}3.48 \\
3.48\end{array}\right.$ & $\begin{array}{l}2.99 \\
3.03\end{array}$ & $\begin{array}{l}.49 \\
.45\end{array}$ & $\begin{array}{l}\text { 2. } 91 \\
2.93\end{array}$ & $2 \frac{1}{2}$ & $2 \frac{1}{2}$ & 2 & 3 & 3 & 3 & $41 / 2$ & 2.9 \\
\hline $6-73$ & do & 1,230 & & & & $-\ldots$ & $21 / 2$ & 2 & 2 & 3 & 3 & 3 & $41 / 2$ & 2.9 \\
\hline
\end{tabular}

1 The amounts of silicon found by analysis did not increase correspondingly with the amounts added, because a portion of the silicon was burned away.

\section{SAND-BLASTING TESTS}

A study was made of blistering and nonblistering irons as to the nature of the surface layer and its relation to blistering. First, it was necessary to find whether the irons varied in resistance to sand blasting. A regulated sand-blast tester for study of abrasion resistance was used. This consisted of a nozzle five-sixteenths inch inside diameter, through which a given amount of Ottawa silica sand or steel grit was passed at an air pressure of 80 pounds. The abrasive impinged on a 3 by 3 inch specimen placed $3 \frac{1}{2}$ inches from the nozzle, at an angle of $45^{\circ}$ to the direction of the blast. The loss of weight of the specimen when blasted under these conditions was taken as a measure of the resistance to that type of abrasion. 
Specimens of $R_{2}$ and $L_{2}$ as well as $L_{2}$, softened by adding nickel, were tested. As shown in Table 14, the average loss of weight was in the direction to be expected; that is, the blistering iron, $\mathrm{L}_{2}$, lost less than the nonblistering iron, $\mathrm{R}_{2}$, but the individual tests did not differentiate the irons sharply. Other factors than the combined carbon of the iron must come in, since $\mathrm{L}_{2}$, plus nickel, with only 0.11 per cent combined carbon (see Table 12), was intermediate between $\mathrm{L}_{2}$ without nickel and $R_{2}$. This method of testing produced sufficient abrasion to cut through the thin surface skin so that differences in hardness which might exist at the surfaces played only a small part in the final figure obtained. The test was repeated, by using successive portions of $600 \mathrm{ml}(1,000 \mathrm{~g})$ of sand and similarly

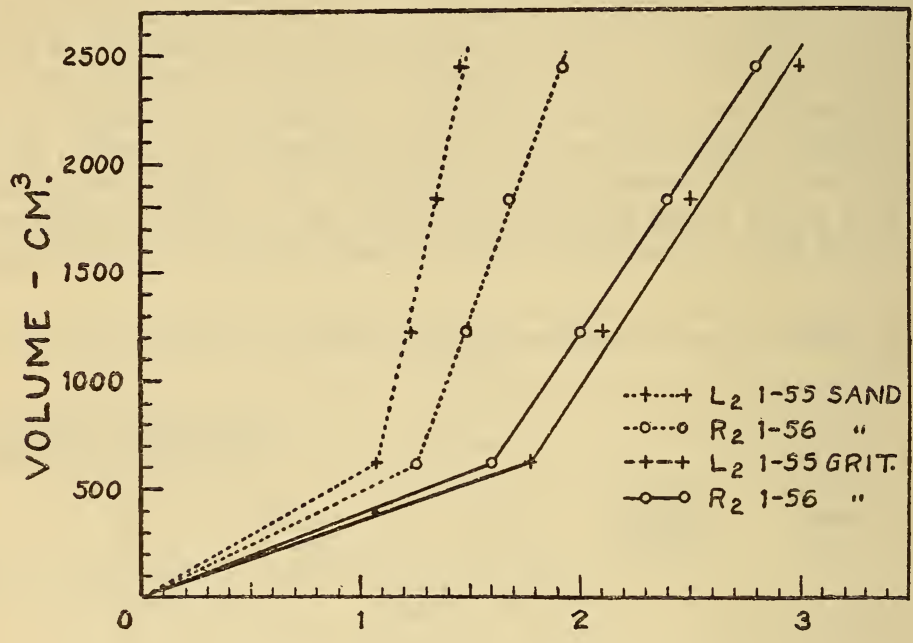

\section{LOSS IN WEIGHT-GMS.}

Figure 12.-Loss in weight of different irons when blasted with different abrasives

Curves show the relation between the volume of abrasive passed through the orifice of sand-blast apparatus and the loss in weight of specimens. The irons used were $\mathrm{L}_{2}, 1-55$ and $R_{2}, 1-56$. The abrasives used were standard Ottawa silica sand and No. 14 steel grit.

with $600 \mathrm{ml}(2,260 \mathrm{~g})$ of steel grit as the abrasive on plates from different heats of irons $L_{2}$ and $R_{2}$. The results are plotted in Figure 12, and show that other heats of these irons fall in the same order as given in Table 14, when sand was used, but that the reverse was true when steel grit was used.

TABLE 14.-Loss in weight during sand-blasting

\begin{tabular}{|c|c|c|c|c|}
\hline $\begin{array}{l}\text { Heat } \\
\text { No. }\end{array}$ & Iran & $\begin{array}{l}\text { Speci- } \\
\text { men No. }\end{array}$ & $\begin{array}{l}\text { Loss in } \\
\text { weight }\end{array}$ & $\begin{array}{l}\text { A verage } \\
\text { loss in } \\
\text { weight }\end{array}$ \\
\hline $2-56$ & $R_{2 \ldots} \ldots$ & 1 & $\begin{array}{l}g \\
1.2\end{array}$ & $\begin{array}{l}g \\
1.6\end{array}$ \\
\hline 2-55 & $\mathrm{L}_{2 \ldots \ldots}$ & $\begin{array}{l}5 \\
7\end{array}$ & $\begin{array}{r}.6 \\
1.0\end{array}$ & .8 \\
\hline 57 & $\mathrm{~L}_{2}+0.5$ per cent & $\begin{array}{r}9 \\
11\end{array}$ & $\begin{array}{l}1.0 \\
1.4\end{array}$ & 1.2 \\
\hline
\end{tabular}


This test does not appear to offer promise as a means of distinguishing blistering from nonblistering iron. The surface layer is evidently too thin to allow satisfactory evaluation of its resistance to abrasion by this means.

\section{STUDY OF BURNED-IN MOLDING SAND}

There appeared to be a possibility that the condition responsible for blistering might be a layer of burned-in sand grains which had not been removed by sand-blasting, although it seemed likely that such material would be inert. Hence, specimens of nonblistering iron were deeply sand-blasted at one end and the amount of sandblasting was decreased sharply toward the other end, where burnedin sand grains could be readily detected with a binocular microscope. These burned-in sand grains did not produce any blisters when the specimens were enameled.

In another test, molding sand was scattered over a deeply sandblasted specimen and the enamel applied as usual. This specimen did not blister. Hence, adhering sand, in itself, does not appear to be a direct cause of blistering, though a burned-in layer would retard the removal of the outside layer of metal during sand-blasting.

Striking confirmatory evidence of this was obtained with a plate of blistering iron $\mathrm{L}_{2}$ which had a firmly adhering scale of burned-in sand. This plate was sand-blasted while held at an angle to the sand stream so that one end was sand-blasted just enough to be visibly free from adhering sand, but not enough to remove this "microchilled layer." The blasting was progressively decreased as the other end was approached. A strip at the end was completely shielded from the blast. On enameling, the shielded strip was entirely free from blisters, although, of course, the adhesion of the enamel was not commercially satisfactory. The sand-blasted area showed progressively increasing blistering as the metal surface was more completely exposed. This test also gave conclusive evidence that blistering is due to a surface reaction and not to the freezing of "occluded" gas in the metal itself, since the portion which was not sand-blasted was as free to evolve such gas as that which was sand-blasted.

\section{COMPOSITION OF SURFACE LAYERS}

Since the surface layer involved is very thin and the surface of a casting is not perfectly smooth, any attempt to mill off the outside layer for chemical examination will result in contamination of it with underlying material. However, a comparison of the results of chemical analysis of the surface and of the body of the casting would appear to give useful indications. Heat $2-55$ of iron $\mathrm{L}_{2}$ with an average blistering index (Table 9 ) of 4.5 -that is, badly blistering-and heat $3-56$ of iron $\mathrm{R}_{2}$ with an average index of 2.4 were compared. The data appear in Table 15.

$106307^{\circ}-30-4$ 
TABLE 15.-Chemical composition of surface layer and interior of cast plates of irons $L_{2}$ and $R_{2}$

\begin{tabular}{|c|c|c|c|c|}
\hline \multirow[b]{2}{*}{ Elements } & \multicolumn{2}{|c|}{$\begin{array}{c}\mathrm{L}_{2} \text { heat No. } \\
\text { blistering) }\end{array}$} & \multicolumn{2}{|c|}{$\begin{array}{l}R_{2} \text { heat No. } 3-56 \text { (weakly } \\
\text { blistering) }\end{array}$} \\
\hline & $\begin{array}{l}\text { Outside } \\
\text { layer } 0.003 \\
\text { inch thick }\end{array}$ & $\begin{array}{l}\text { Comparison } \\
\text { layer (0.01 } \\
\text { inch thick) } \\
\text { several hun- } \\
\text { dredths inch } \\
\text { beneath the } \\
\text { surface }\end{array}$ & $\begin{array}{c}\text { Outside } \\
\text { layer } 0.003 \\
\text { inch thick }\end{array}$ & $\begin{array}{l}\text { Comparison } \\
\text { layer (0.01 } \\
\text { inch thick) } \\
\text { several hun- } \\
\text { dredths inch } \\
\text { beneath the } \\
\text { surface }\end{array}$ \\
\hline 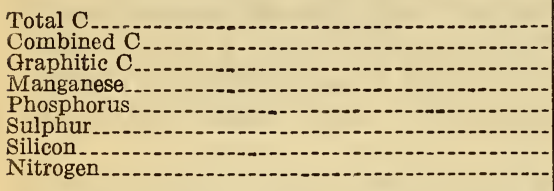 & $\begin{array}{l}2.71 \\
.45 \\
2.26 \\
.61 \\
.435 \\
.044 \\
2.42 \\
.0033 \\
\end{array}$ & $\begin{array}{l}3.54 \\
.34 \\
3.20 \\
.73 \\
.500 \\
.037 \\
2.63 \\
<.0005 \\
\end{array}$ & $\begin{array}{l}2.84 \\
.42 \\
2.42 \\
.45 \\
.605 \\
.031 \\
2.33 \\
.0015 \\
\end{array}$ & $\begin{array}{l}3.31 \\
.27 \\
3.04 \\
.61 \\
.835 \\
.022 \\
2.46 \\
<.0005 \\
\end{array}$ \\
\hline Total & 6.22 & 7.44 & 6.26 & 7.24 \\
\hline Iron by difference.-...- & 93.78 & 92.56 & 93.74 & 92.76 \\
\hline
\end{tabular}

It is seen that in both cases there is at the surface less total carbon manganese, phosphorus, and silicon, but more combined carbon and sulphur; that is, the surface skin seems to be higher in iron than the interior, which segregation is to be expected.

The increase in combined carbon appears especially significant, since that will obviously accompany the presence of a hard surface layer, which is difficult to remove by sand-blasting. There seems, therefore, to be a "microchilled" surface layer (micro refers here to the thickness of the chilled layer), which is apparently not necessarily controlled by the propensity of the iron to chill in the ordinary sense of giving a visibly thick layer of white iron on rapid cooling, and which may be different in its nature from an ordinary chilled layer.

\section{MICROSCOPIC EXAMINATION OF "MICROCHILLED" LAYER}

The difference in composition at the extreme surface is probably greater than is shown by the chemical analysis, since in machining off the surface layer, thin as it was, doubtless some material more nearly approaching the body of the casting in composition was included. The microstructure of the surface of iron $R_{2}$, heat $3-56$ (fig. 13D), indicates it to contain much less combined carbon than the surface of iron $\mathrm{L}_{2}$, heat 2-55 (fig. 14D). The surface of the best heat (4-55) of iron $\mathrm{L}_{2}$ (fig. 15) appears to be more completely broken up into ferrite and graphite than is the case of heat $2-55$.

\section{EFFECT OF NITROGEN}

The higher nitrogen content (Table 15) of the thin surface layer than that of the interior calls for attention, especially as the strongly blistering iron shows double the amount of nitrogen in the surface that the weakly blistering one does. The nitrogen might play a part in two different ways. If it is present as iron nitride, which decomposes at or below enameling temperatures (10), it constitutes a possible source of gas bubbles. If, on the other hand, it is present as chromium or titanium nitrides, these might decompose slightly at enameling temperatures, but the greater part of the nitrogen would 


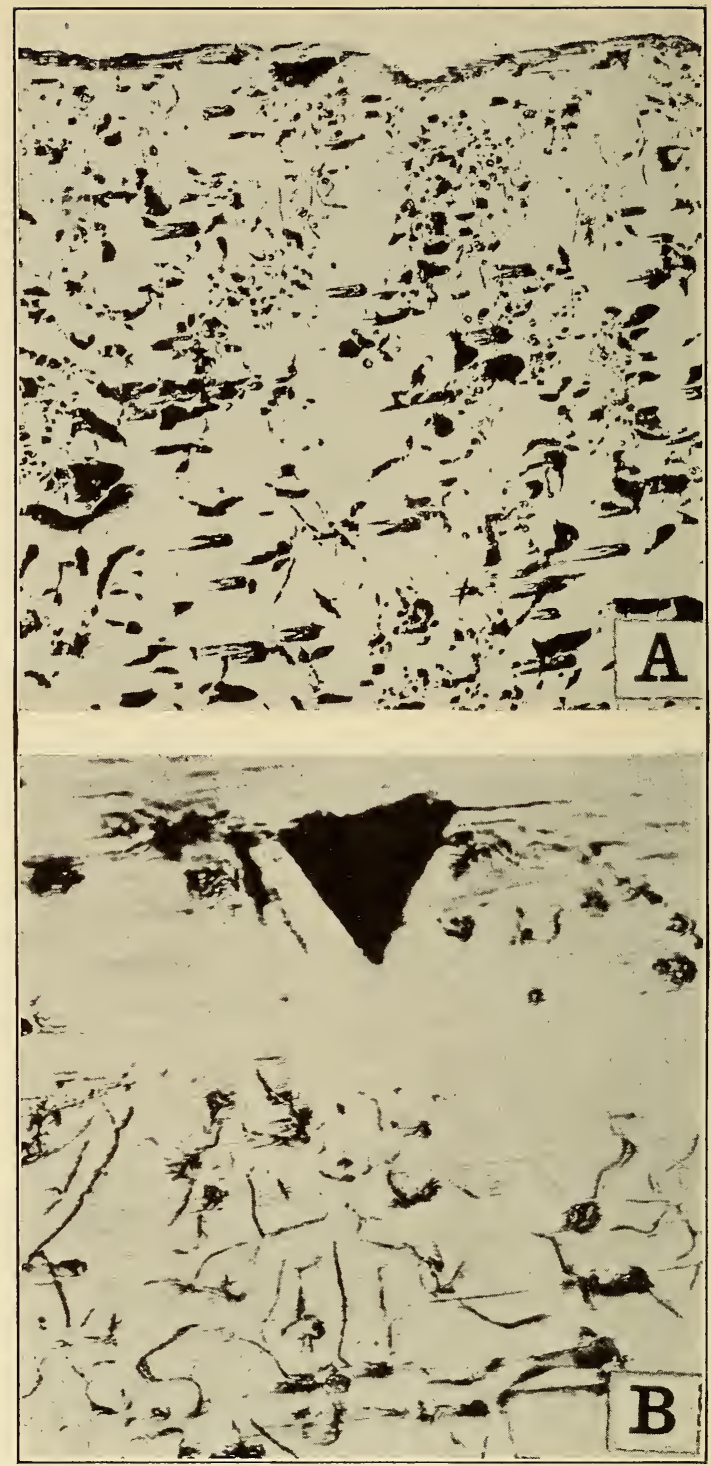

Figure 13.-Cross section of surface layer. Iron $R_{2}$; heat 3-56

Drag side, composition shown in Table 15. (Surface of specimens at top of these and all following micrographs. Specimens not enameled were nickel and copper plated before sectioning.) $A$, polished. $\times 100 ; B$, polished. $\times 500$. 


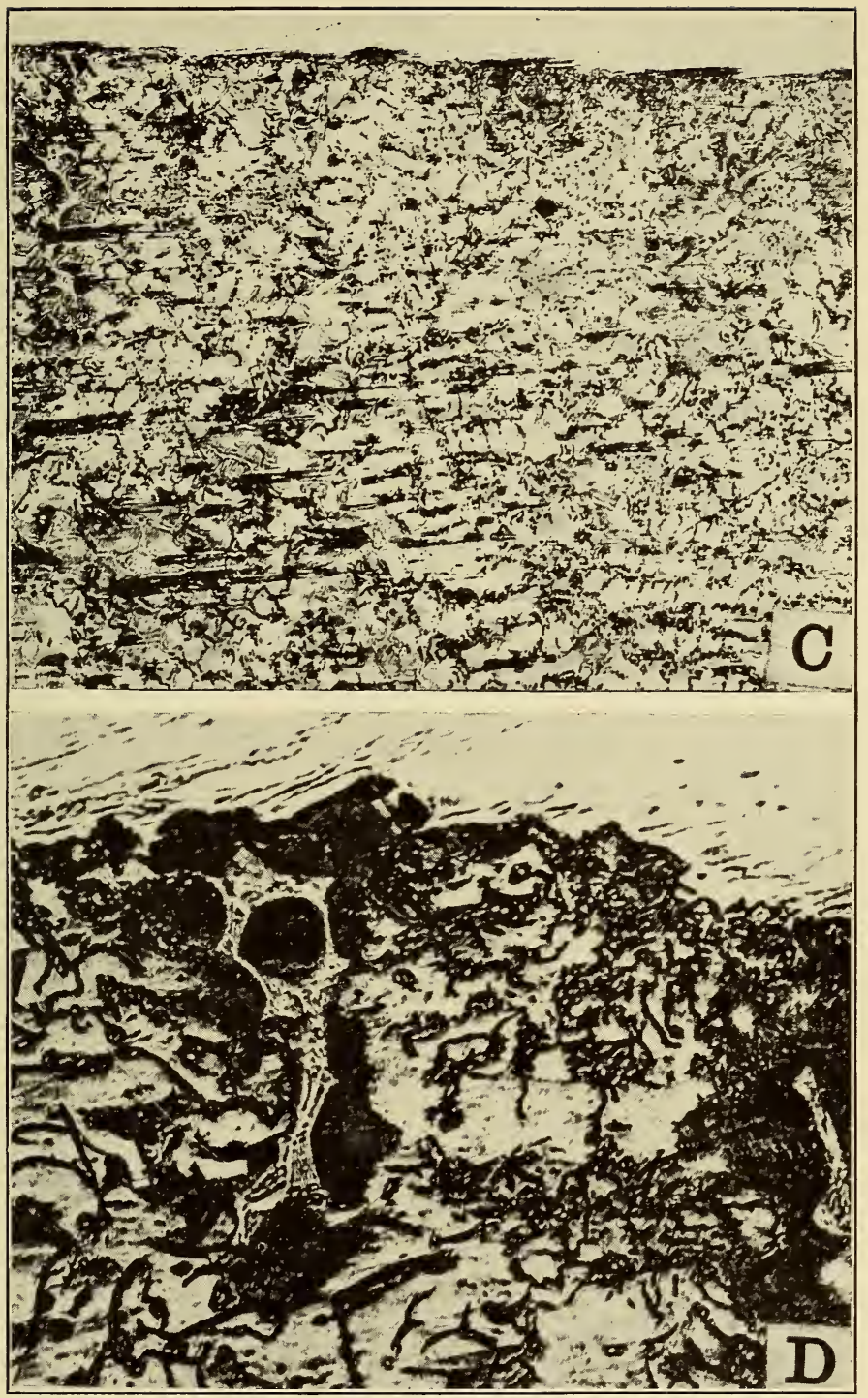

Figure 13.-Cross section of surface layer. Iron $R_{2}$; heat 3-56Continued

$C$, etched in 5 per cent picric acid. $\times 100 ; D$, etched in 5 per cent picric acid. $\times 500$. 
be retained and tend to form a hard skin as in the case of special steels containing aluminum and chromium, heated in an atmosphere of ammonia (11).

That nitrides probably play no direct part in the formation of blisters was indicated by the following test: Half of the drag side of strips 6 by $3 / 4$ by $3 / 16$ inches of $R_{2}$ iron, heat 3-56, were lightly machined and both drag and cope sides were given the standard sand-blasting. These strips then were heated to $500^{\circ} \mathrm{C}\left(930^{\circ} \mathrm{F}\right.$.) in a stream of ammonia for periods of 1,2 , and 5 hours according to the usual method employed in forming nitride coatings. The nitrided strips were then very lightly sand-blasted and the cope side of each strip machined off to give a sample for chemical analyses for nitrogen, the layer removed being 0.003 inch thick. Analysis showed the nitrogen content of the surface layer of the three to be $0.05,0.08$, and 1.0 per cent, respectively. On enameling these specimens on the drag side, in the usual fashion, there was no sign of blisters either on the machined area or on the nonmachined area though both contained nitrogen in far higher proportions than that found on the surface layer of the blistering iron.

That it is comparatively easy to produce a nitride skin on ordinary cast iron is probably not well known. Osterman (11), however, has mentioned the commercial nitriding of cast iron for water pumps. Wheeler (11) found that washed metal (almost pure iron-carbon alloy of 3.65 per cent carbon) was hardly affected on heating in ammonia gas while a white cast iron of 2.15 per cent carbon, 0.33 per cent silicon, 0.12 per cent manganese, 0.20 per cent phosphorus, 0.21 per cent sulphur, readily formed a nonadherent surface layer containing almost pure iron nitride, beneath which the metal was somewhat decarburized.

There is some evidence that the minute amount of nitrogen introduced in melting steel, and presumably in cast iron, may be more stable than the nitride formed on the surface by heating in ammonia gas, and, hence, might decompose at a different temperature, perhaps just a temperature at which the gas would be caught in the enamel, so the test may not entirely exclude the possibility that nitrogen causes blistering.

\section{SPECTROSCOPIC EXAMINATION}

There is a possibility that traces of elements that would form hard nitrides might play a part in the formation of a hard skin. Spectroscopic analysis of the strongly blistering iron, $\mathrm{L}_{1}$, and the weakly blistering iron, $R_{1}$, made early in the investigation, showed nickel to be absent, but titanium, vanadium, chromium, traces of aluminum, and, of course, copper to be present in addition to the elements usually reported in chemical analysis of cast iron. Chemical analysis for these elements and for total oxygen and hydrogen gave the results shown in Table 16.

TABLE 16.-Content of elements not ordinarily determined in cast iron

\begin{tabular}{|c|c|c|c|c|c|c|c|c|}
\hline $\begin{array}{l}\text { Designation } \\
\text { of irons }\end{array}$ & Character & $\mathrm{Cu}$ & $\mathrm{Ti}$ & $\mathrm{Cr}$ & $\mathrm{V}$ & Al & 0 & स \\
\hline $\begin{array}{l}\mathrm{L}_{1} \ldots \ldots \ldots \ldots \\
\mathrm{R}_{1} \ldots \ldots \ldots \ldots\end{array}$ & $\begin{array}{l}\text { Strongly blistering-.... } \\
\text { Weakly blistering }\end{array}$ & $\mid \begin{array}{r}\text { Per cent } \\
0.07 \\
.03\end{array}$ & $\begin{array}{c}\text { Per cent } \\
0.08 \\
.15\end{array}$ & $\begin{array}{c}P e r \text { cent } \\
0.025 \\
.010\end{array}$ & $\begin{array}{c}\text { Per cent } \\
0.030 \\
.025\end{array}$ & $t \begin{array}{c}\text { Per cent } \\
\text { (1) } \\
\text { (1) }\end{array}$ & $\mid \begin{array}{c}\text { Per cent } \\
0.002 \\
.004\end{array}$ & $\begin{array}{r}\text { Per cent } \\
0.0007 \\
.0005\end{array}$ \\
\hline
\end{tabular}

1 Less than 0.005 per cent. 
Since copper is present in all pig iron and is not a carbide or nitride forming element, it can hardly be suspected of having anything to do with blistering. Vanadium and aluminum are essentially identical in the two irons. Titanium, a nitride-forming element, might be suspected, but the fact that the strongly blistering iron contains only half as much as the weakly blistering one seems to remove titanium from suspicion.

Gilmore (12) points out that aluminum and titanium act like silicon in favoring the softening of iron by the precipitation of graphite, and states that both vanadium and chromium assist carbon in remaining in the combined form, one-quarter of 1 per cent of chromium holding 0.80 per cent carbon in the combined form after a malleableizing anneal.

\section{EFFECT OF CHROMIUM}

Chromium was present in the strongly blistering iron, $\mathrm{L}_{1}$, in appreciably larger amount than in the weakly blistering, $R_{1}$.

Since small amounts of chromium are known to increase the chill on cast iron $(13,14)$ and to interfere considerably with the malleableizing anneal of malleable cast iron, by tending to retain the carbon in the combined form, there is a possibility that even this slight difierence in chromium content might favor the formation or retention of a surface layer higher in combined carbon, hence, harder and more difficult to remove in sand blasting.

To examine further the hypothesis that the chromium content might have a connection with the propensity toward blistering, the irons used in the latter part of the investigation were analyzed for chromium, with the results shown in Table 17.

TABLE 17.-Enamel ratings of irons with different chromium contents

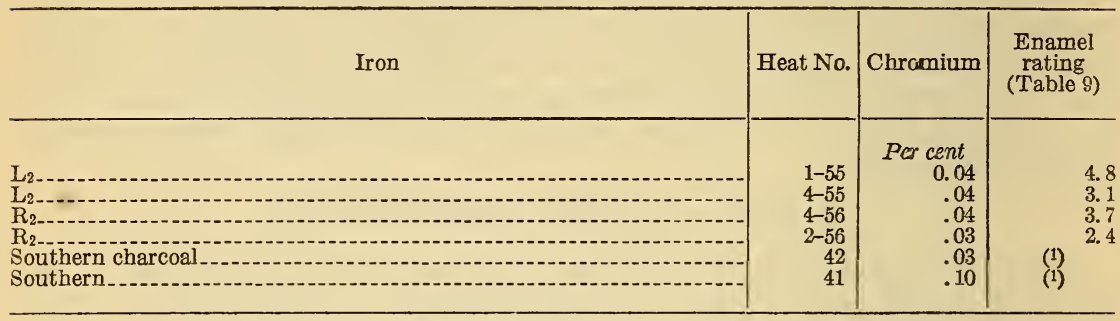

1 Ratings not comparable, since irons were tested only at the bureau.

It will be noted that the strongly blistering iron, $\mathrm{L}_{2}$, and the worse heat (4-56) of the weekly blistering iron, $R_{2}$, contain slightly more chromium than the better heat (2-56) of $R_{2}$. While the difference is very slight, it is in the direction of damage due to chromium.

Although the enamel rating obtained with southern iron is not comparable to the other ratings, there is little doubt that it has as little blistering tendency as any iron studied. Yet it contains much more chromium than any of the others, so that the mere presence of chromium can not be taken as the sole cause for blistering. This can not be regarded as entirely eliminating chromium from consideration, because the formation of the microchilled layer is very evidently a matter of delicate balance and the effect of chromium in irons of different composition as to other elements may not be the same. 


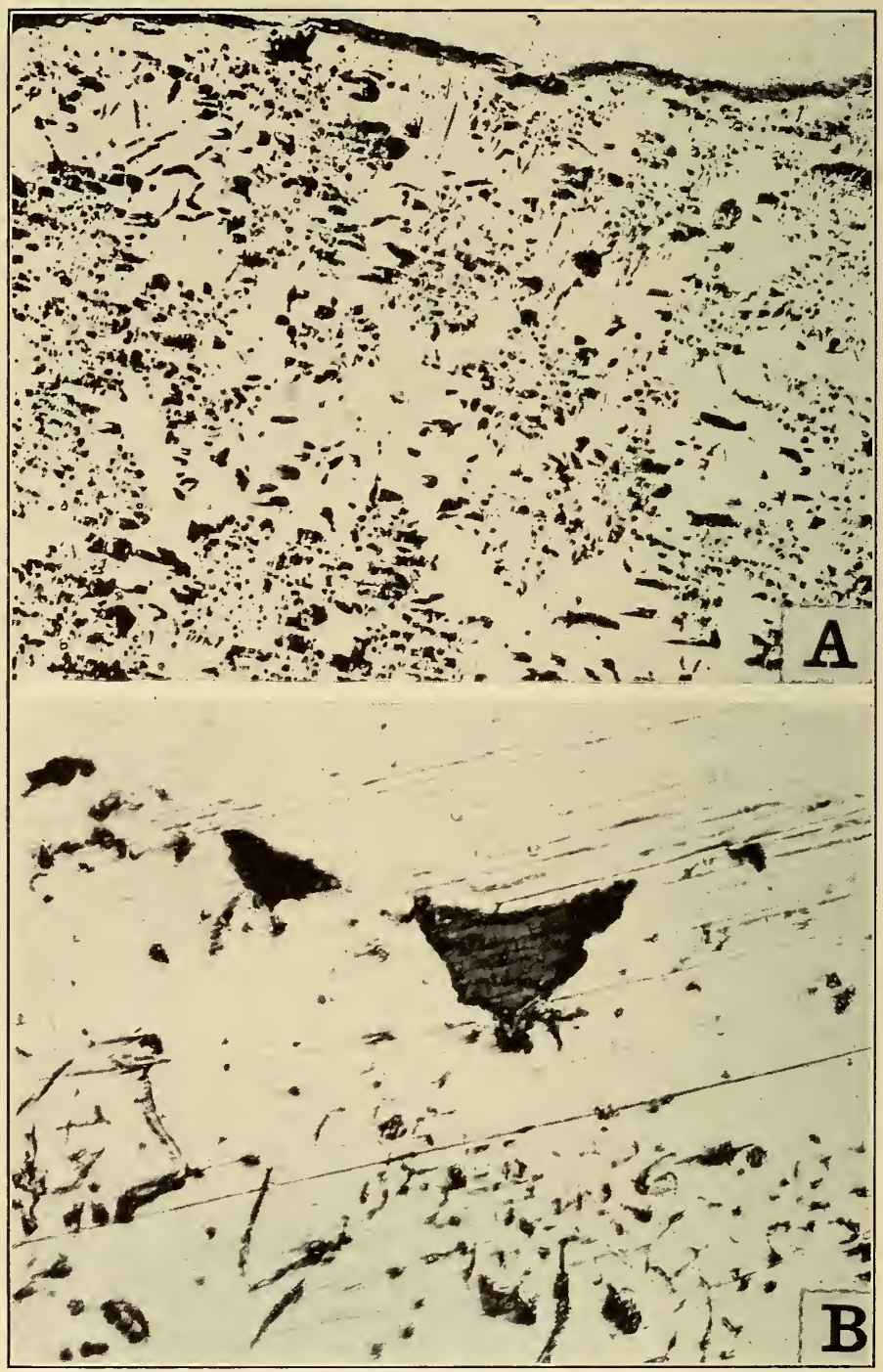

FIgURe 14.-Cross section of surface layer. Iron $L_{2}$; heat $2-55$ Drag side, composition shown in Table 15. A, polished. $\times 100 ; B$, polished. $\times 500$. 
B. S. Journal of Research, RPI79

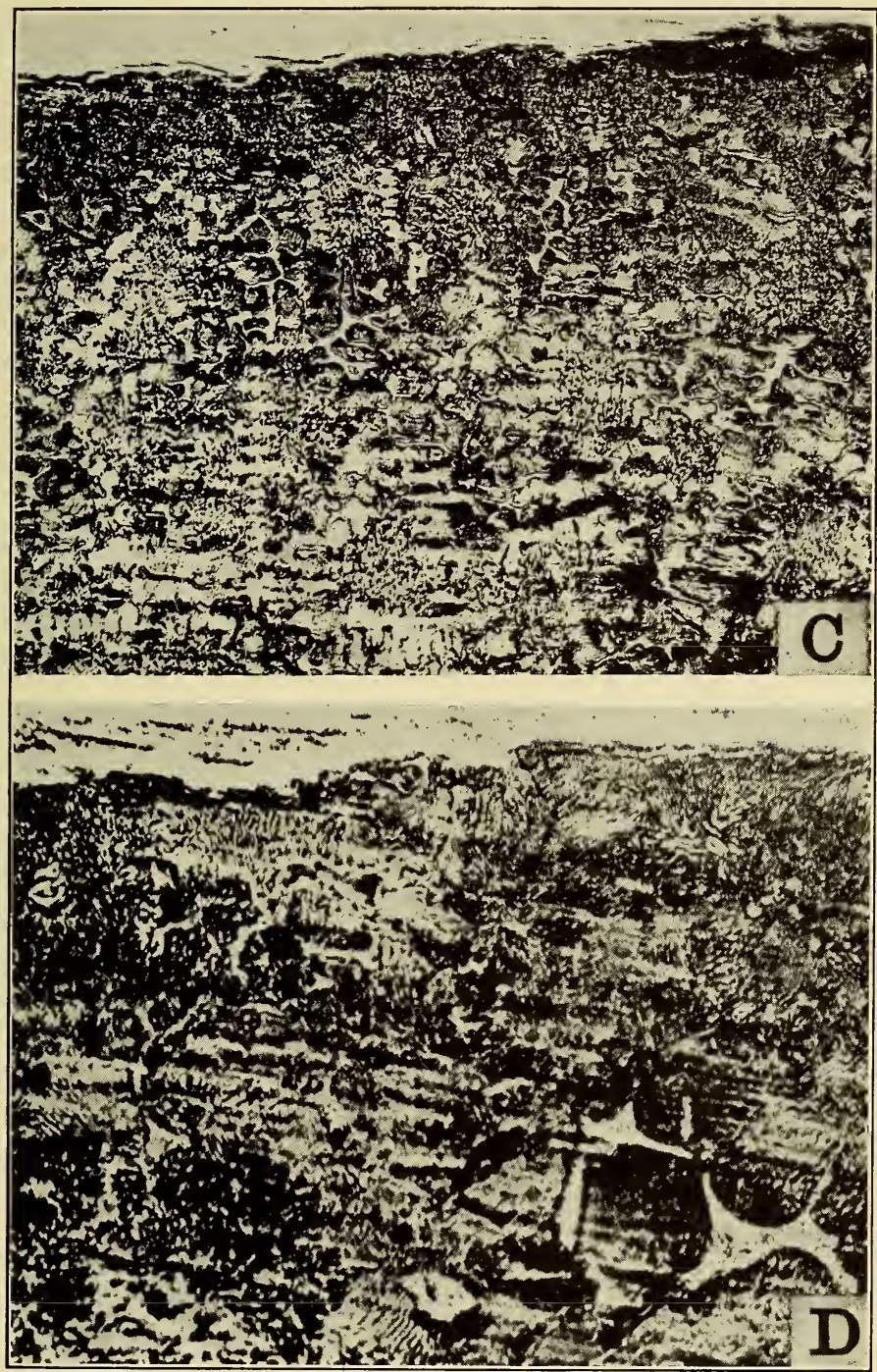

Figure 14.-Cross section of surface layer. Iron $L_{2}$; heat 2-55Continued

$C$, etched in 5 per cent picric acid. $\times 100 ; D$, etched in 5 per cent picric acid. $\times 500$. 


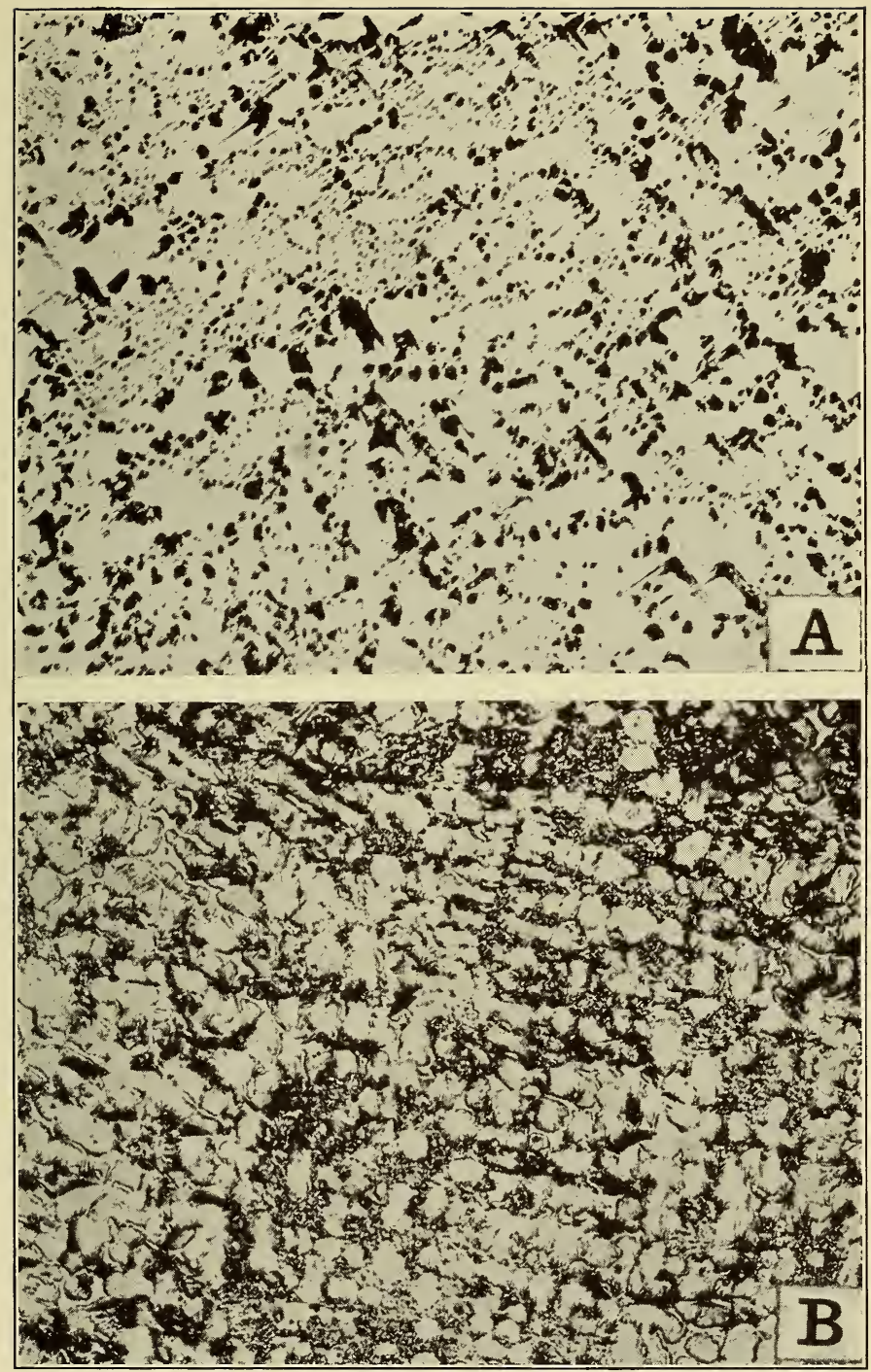

Figure 15.-Cross section of surface layer. Iron $L_{2}$; heat 4-55

Drag side; this heat was less strongly blistering than the companion heats $(1-55,2-55$, and 3-55) of iron $L_{2}$. $A$, polished. $\times 100 ; B$, etched in picric acid. $\times 100$. 
B. S. Journal of Research, RPI79

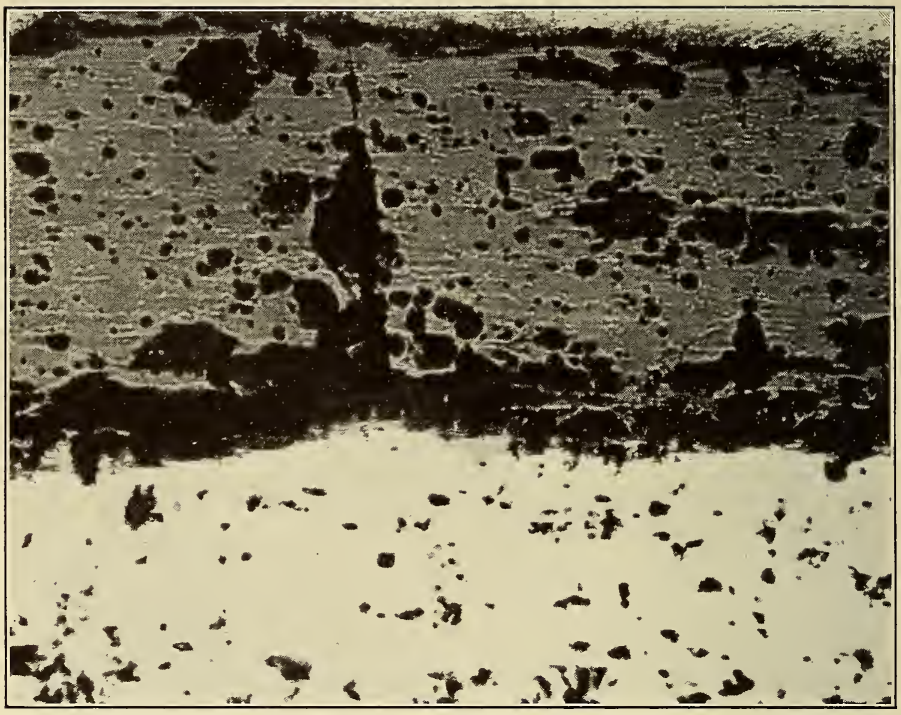

Figure 16.-Cross section of enamel and surface layer of iron. Southern iron; heat 41

Polished. $\times 100$. Note interconnected channels in the enamel. No blisters were observed on this specimen. Ground coat fired 10 minutes at $875^{\circ} \mathrm{C}$. $\left(1,605^{\circ} \mathrm{F}\right.$.) and cover coat 8 minutes at $800^{\circ} \mathrm{C}$. $\left(1,470^{\circ} \mathrm{F}\right.$.). 
In order to study the chromium problem more thoroughly, an experiment was made to see whether addition of chromium to the weakly blistering northern iron, $R_{2}$, increased its propensity to blister. As may be seen from Table 18, a noticeable increase in blistering accompanied the addition of 0.03 per cent chromium, but the larger additions ( 0.05 per cent and 0.10 per cent) showed no effect.

TABLE 18.-Enameling tests of irons $R_{2}$ and $L_{2}$ without and with additions of chromium (electric furnace melts)

\begin{tabular}{|c|c|c|c|c|c|c|c|c|c|c|}
\hline \multirow{2}{*}{$\begin{array}{l}\text { Plate } \\
\text { No. }\end{array}$} & \multirow{2}{*}{ Irons } & \multirow{2}{*}{$\begin{array}{c}\text { Approxi- } \\
\text { mate } \\
\text { pouring } \\
\text { tempera- } \\
\text { ture }\end{array}$} & \multicolumn{8}{|c|}{$\begin{array}{l}\text { Standard enamel ratings at firing time shown in } \\
\text { minutes }\end{array}$} \\
\hline & & & $3 \frac{1}{2}$ & 5 & $71 / 2$ & 10 & $12 \frac{1}{2}$ & 15 & $171 / 2$ & $\begin{array}{l}\text { A ver- }- \\
\text { age }\end{array}$ \\
\hline & & & & & & & & & & \\
\hline $2-71$ & $\mathrm{R}_{2}+0.03$ per cent $\mathrm{Cr}$ & & $\begin{array}{l}4 \\
4\end{array}$ & $\frac{1}{21}$ & ${ }_{4}^{2}$ & 2 & $\begin{array}{c}3 \\
3\end{array}$ & 2 & $21 / 2$ & 2. \\
\hline $3-71$ & $\mathrm{R}_{2}+0.05$ & 1,400 & $\begin{array}{l}7 \\
4\end{array}$ & 1 & 1 & 2 & $21 / 2$ & 3 & 3 & 2. \\
\hline $4-71$ & $\mathrm{R}_{2}+0.1$ per cent $\mathrm{Cr}$ & 1,4 & $31 / 2$ & 1 & 2 & 2 & 3 & $21 / 2$ & 3 & 2. \\
\hline $\begin{array}{c}5-71 \\
6-71\end{array}$ & 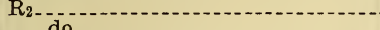 & & 3 & 2 & 3 & 2 & 3 & 3 & 3 & 2. \\
\hline $1-72$ & $\mathrm{u}_{2-\mathrm{ac}}$ & $\begin{array}{l}1,200 \\
1,400\end{array}$ & ${ }_{21}^{4} /$ & $21 \%$ & $21 / 3$ & $31 / 2$ & $\frac{31 / 2}{5}$ & $\frac{21 / 2}{5}$ & $\frac{2}{5}$ & 4.2. \\
\hline $2-72$ & 03 per cent & 1,400 & 3 & $21 / 2$ & $21 / 2$ & 5 & 5 & 5 & 5 & 4. \\
\hline $\begin{array}{l}3-72 \\
4-72\end{array}$ & $\mathrm{~L}_{2}+0.05$ per cent $\mathrm{Cr}$ & & $3_{3}^{3}$ & $21 / 2$ & & 4 & 5 & 5 & 5 & $\begin{array}{l}3.9 \\
4.0\end{array}$ \\
\hline $5-72$ & from furnace 14 minut & & & & & & & & & \\
\hline $6-72$ & af & 1,400 & $21 / 2$ & 2 & $21 / 2$ & 5 & 5 & 5 & 5 & 3.9 \\
\hline & after tapping of $5-72$ & 1,320 & $31 / 2$ & $21 / 2$ & 5 & $41 / 2$ & $41 / 2$ & 5 & 5 & 4.3 \\
\hline
\end{tabular}

Similar experiments were carried out with additions of chromium on the blistering iron $\mathrm{L}_{2}$ with the purpose of stabilizing combined carbon in the surface layer of those castings. As is shown in Table 18 and Figure 11 1/2, chromium, in the quantities 'used, had practically no effect.

\section{ERRATIC BEHAVIOR OF PIG IRON}

The erratic behavior of iron containing small amounts of chromium, commented on above, reminds one that many cases are known in which inexplicable differences are found in the behavior of different lots or heats of cast iron that do not differ materially in composition as determined by ordinary chemical analysis $(15,16,17)$. Sometimes this can be explained on the basis of a delicate balance among elements $(18,19)$.

Piwowarsky (18) finds that the combined carbon content of gray iron castings is affected by the temperature and duration of superheating of the melt. These factors also produce variations in the number and size of graphite nuclei upon which graphite will be precipitated on freezing.

\section{STUDY OF GASES AND GAS-FORMING ELEMENTS}

\section{OXYGEN}

In work by Herty and Gaines (29), of the Bureau of Mines, it has been found that pig iror tapped after a blast furnace "slip" may contain an excessive amount of suspended silica or silicates in a very fine state of subdivision, and that these, being difficult to reduce or flux out in steel making, give inferior steel. 
It does not, however, appear likely that the presence or absence of such inclusions is directly responsible for the difference between blistering and nonblistering irons. If the suspended particles are not reduced by the carbon of the iron while it is molten, it is not likely that they will be reduced by it in the solid metal when heated only to enameling temperatures. Hence, the evolution of $\mathrm{CO}$ from within the metal itself by reaction of inclusions during enameling is not a plausible explanation for blisters. Moreover, the vacuum-fusion method for total oxygen determines the oxygen of silica and silicates, hence will reflect the amount of inclusions present. As shown in Table 16, however, very little difference was found in the oxygen content of the two irons, the blistering iron containing even slightly less oxygen than the nonblistering one.

\section{HYDROGEN}

The difference in the hydrogen content of the two irons is within the precision of the analytical method, and since the amounts are so nearly the same, no indication is given that hydrogen is a factor.

\section{SULPHUR}

There is also a possibility that the gas might come from the oxidation of manganese sulphide or iron sulphide at the surface of the metal. To examine this hypothesis, sulphur determinations were made on the surface layer ( 0.003 inch thick) milled off of specimens of the strongly blistering iron, $\mathrm{L}_{2}$, heat $2-55$, after the usual sand blasting, and of other specimens of the same heat that had been put through the heating cycles of the enameling process under oxidizing conditions but without enamel. These cycles consisted of heating in air $12 \frac{1}{2}$ minutes at $875^{\circ} \mathrm{C}$. $\left(1,605^{\circ} \mathrm{F}\right.$.), cooling in air and again heating in air 8 minutes at $800^{\circ} \mathrm{C}$. $\left(1,470^{\circ} \mathrm{F}\right.$.). The amount of sulphur was not changed, being 0.050 per cent in each case, and this indicated that there is no preferential oxidation of sulphur and that the blister forming gas is probably not $\mathrm{SO}_{2}$.

\section{GAS IN BLISTERS}

If the composition of the gas in the blisters could be determined, one would have a very useful clue as to their source. On piercing the blisters of an enameled specimen under water, collecting and analyzing the gas, it was found to be air. Microscopic examination of the cross sections of enamel coatings (fig. 16) indicated that many of the internal bubbles were connected by channels with each other and frequently with the air, so that whatever the original gas they contained during the process of blistering, it may escape and be replaced by air. Hence, it was necessary to collect the gas formed in the act of blistering.

First of all a determination of whether the enamel alone and the iron alone evolve gas on heating was necessary.

That gas is evolved from the enamel alone is shown by the fact that the ground and cover coats used in the standard enameling procedure (including the clay used) dried as in the enameling process, exposed to the air for 42 hours, dried again at $100^{\circ} \mathrm{C}$. for 1 hour and finally heated to $500^{\circ} \mathrm{C}$. for 12 minutes, lost weight as follows: 


\begin{tabular}{|c|c|c|}
\hline & \multicolumn{2}{|c|}{$\begin{array}{c}\text { Total loss in weight } \\
\text { up to-- }\end{array}$} \\
\hline & $100^{\circ} \mathrm{C}$. & $500^{\circ} \mathrm{C}$. \\
\hline $\begin{array}{l}\text { Ground coat } \\
\text { Cover coat }-. .1\end{array}$ & $\begin{array}{c}\text { Per cent } \\
0.53 \\
.07\end{array}$ & $\begin{array}{c}\text { Per cent } \\
2.24 \\
.62\end{array}$ \\
\hline
\end{tabular}

Presumably the greater part of the loss at $500^{\circ} \mathrm{C} .\left(930^{\circ} \mathrm{F}\right.$.) represents water of constitution of the clay, or at least firmly adsorbed moisture.

The ground coat and the clay used in it were then tested at enameling temperatures. The ground coat slip (containing 15 per cent clay on a dry basis) after first drying for an hour at $130^{\circ}$ to $140^{\circ} \mathrm{C}$. $\left(265^{\circ}\right.$ to $285^{\circ} \mathrm{F}$.) followed by heating at $830^{\circ} \mathrm{C}$. $\left(1,525^{\circ} \mathrm{F}\right.$.) for eight minutes, gave off 0.10 per cent of $\mathrm{CO}_{2}$. The clay alone gave off, beside an undetermined amount of moisture, 0.43 per cent $\mathrm{CO}_{2}$. Good agreement in both figures was obtained in duplicate determinations. Hence, the ground coat slip gives off 0.06 per cent $\mathrm{CO}_{2}$ due to the clay and 0.04 per cent $\mathrm{CO}_{2}$ due to the frit itself. This amount of oxidized carbon, however, is of little importance as compared with amounts of similar gases from other sources, as will be shown later.

\section{GAS AND IRON ALONE HEATED IN NITROGEN}

There were then selected for the subsequent tests, specimens of iron varying in their tendency toward blistering, as follows:

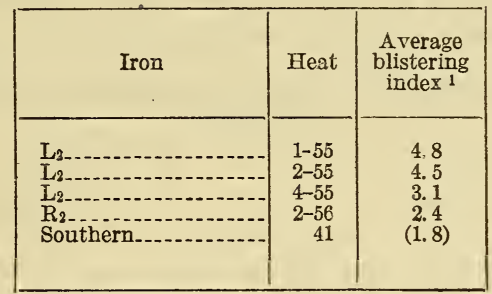

1 See Table 9

The average rating (1.8) of southern iron, heat 41 (poured at $1,400^{\circ}$ C. $\left.\left(2,550^{\circ} \mathrm{F}.\right)\right)$ was obtained from tests made at the bureau only, hence, is not comparable with other averages which include results obtained in several laboratories. The first four specimens are northern irons. It is to be noted that iron $\mathrm{L}_{2}, 4-55$, is much less blistering than the other heats of $\mathrm{L}_{2}-55$.

The total surface area of each sample (both sides and all edges) was about 5 square inches, and each weighed about $50 \mathrm{~g}$. These samples were sand-blasted in a manner corresponding to the usual method of preparation for enameling, placed in a furnace through which the desired gas was passing, and heated. Any $\mathrm{CO}_{2}$ and $\mathrm{CO}$ formed were collected in an analytical train and determined gravimetrically. In the first series, after drying for an hour at $150^{\circ} \mathrm{C}$. $\left(300^{\circ} \mathrm{F}\right.$.), the specimens were heated for 15 minutes in a stream of oxygen-free nitrogen at $875^{\circ} \mathrm{C} .\left(1,605^{\circ} \mathrm{F}.\right)$. The results are given in Table 19 . 
TABLE 19.-Weight of evolved gases from iron specimens heated in oxygen-free nitrogen

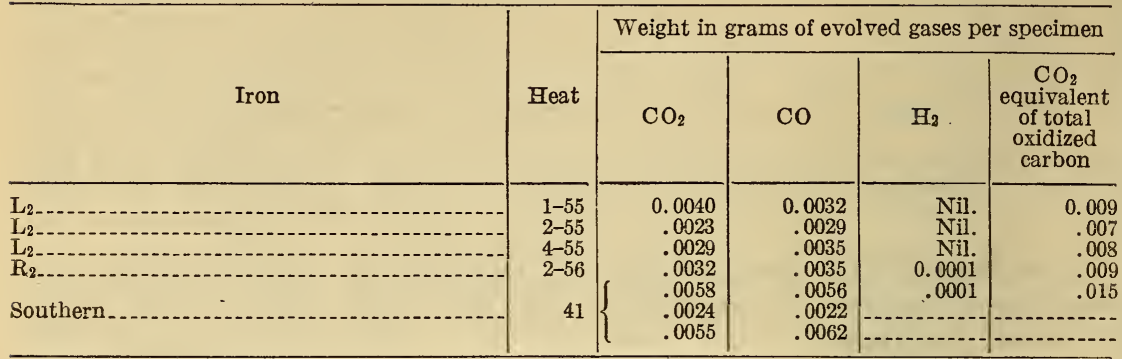

Although the nitrogen was treated to remove the bulk of any oxygen present, the specimens after heating were darkened slightly, southern iron 41 being the darkest. The uniformity of the amount of equivalent $\mathrm{CO}_{2}$ from the $\mathrm{L}_{2}$ and $\mathrm{R}_{2}$ specimens indicates that the test does not differentiate between strongly and weakly blistering irons, and probably reflected merely the amount of air adsorbed on the metal surface or that entering the nitrogen-filled tube when the specimen is inserted, or possible traces of oxygen remaining in the nitrogen.

\section{GAS FROM IRON ALONE HEATED IN AIR}

In the next series of tests the specimens were heated in $\mathrm{CO}_{2}$-free air instead of in nitrogen. The specimens dried as before, were heated for 15 minutes at $875^{\circ} \mathrm{C}$. $\left(1,605^{\circ} \mathrm{F}\right.$.). While the carbon of the cast iron may burn to $\mathrm{CO}$ at the surface, the $\mathrm{CO}$ will, under the test conditions, be burned almost entirely to $\mathrm{CO}_{2}$, only traces of $\mathrm{CO}$ being collected in the analytical train. These traces were calculated as the equivalent $\mathrm{CO}_{2}$. The complete results are given in Table 20.

TABLE 20.-Weight of total $\mathrm{CO}_{2}$ and $\mathrm{H}_{2}$ evolved from iron specimens heated in $\mathrm{CO}_{2}-$ free air

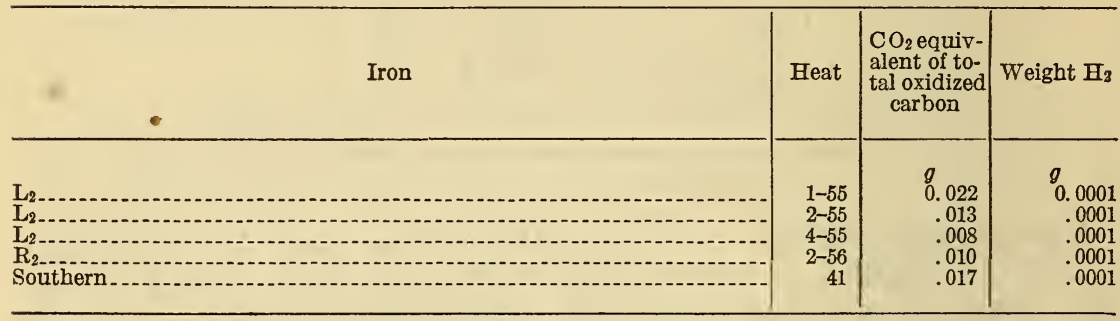

Under the above conditions of heating, the most strongly blistering castings produced the most $\mathrm{CO}_{2}$, although the weakly blistering southern iron produced nearly as large an amount of $\mathrm{CO}_{2}$ as one of the strongly blistering irons. The appearance of the oxidized surface, however, did show a consistent relation to the blistering tendency. The specimens of the $1-55$ and $2-55$ heats of iron $L_{2}$ had a decidedly rough surface. Heat $4-55$ of $\mathrm{L}_{2}$, which was a good example of weakly blistering iron, was decidedly smoother and had the same appearance as the specimen of iron $R_{2}$ heat $2-56$. The southern iron was still smoother, having a velvety appearance. In neither of the above two series of tests was there a certainly detectable amount of hydrogen evolved. 


\section{GAS FROM ENAMEL-COATED IRONS HEATED IN NITROGEN}

In a third series of gas-evolution tests, the iron specimens were coated on all sides with the standard ground coat, about $0.9 \mathrm{~g}$ of wet ground coat being applied. The specimens were dried at $80^{\circ}$ to $90^{\circ}$ C. for 40 minutes. They were then inserted into the hot furnace tube through which oxygen-free nitrogen was passing, and heated at $875^{\circ} \mathrm{C}$. $\left(1,605^{\circ} \mathrm{F}\right.$.) for 20 minutes. The firing time was longer than in the regular enameling tests because of the smaller heat capacity of the furnace as compared with furnaces for regular enameling. Specimens coated on one side only and fired for a shorter period in preliminary tests had the appearance of being underfired.

Since the ground coat contained clay with water of constitution, the gas passing from the tube was scrubbed free from water vapor by a drying tower. The equivalent of the total oxidized carbon evolved is shown in Table 21. All figures are averages of two closely agreeing determinations.

TABLE 21.-Gas evolved from cast-iron specimens coated with ground enamel and heated in nitrogen

\begin{tabular}{|c|c|c|c|}
\hline Iron & Heat & $\begin{array}{l}\mathrm{CO}_{2} \text { equiv- } \\
\text { alent of to- } \\
\text { tal oxidized } \\
\text { carbon }{ }^{1}\end{array}$ & Weight $\mathrm{H}_{3}$ \\
\hline 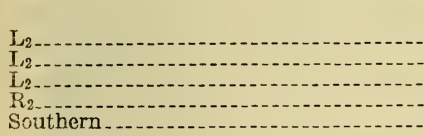 & $\begin{array}{r}1-55 \\
2-55 \\
4-55 \\
2-56 \\
41\end{array}$ & $\begin{array}{l}g \\
0.008 \\
.008 \\
.006 \\
.006 \\
.007\end{array}$ & $\begin{array}{l}\text { Nil. } \\
\text { Nil. } \\
\text { Nil. } \\
\text { Nil. } \\
0.0001\end{array}$ \\
\hline
\end{tabular}

1 Of this $\mathrm{CO}_{2}$ only $0.0305 \mathrm{~g}$ was in all cases due to the ground coat alone.

It would be assumed that much of the air adsorbed on the surface of the iron specimens before spraying with ground coat would be displaced by the water of the ground coat, but the dry ground coat would presumably adsorb air. It is not possible, therefore, to tell whether the oxygen of the $\mathrm{CO}_{2}$ comes from adsorbed air, air admitted in inserting the specimens into the tube, or from oxidation of the lead oxide of the ground coat. By comparing the four heats of northern irons it might appear that the more strongly blistering ones have the carbon at their surfaces in more readily oxidizable form, but the southern iron is out of line with this explanation.

The surface appearance of the specimens was again very characteristic, each pair of duplicate specimens agreeing closely in appearance. The specimens of iron $L_{2}$ heats $1-55$ and 2-55 (the most strongly blistering ones) had the ground coat in very rough, pebbly form. Heats $L_{2}, 4-55$ and $R_{2}, 2-56$ (weakly blistering) had the coat in less rough form, while the weakly blistering southern iron was very smoothly and evenly coated. The machined edges of all the specimens were smoothly and uniformly coated with a glossy coat. The appearance of the specimens is shown in Figure 17. The difference in surface roughness is more likely an effect of some condition leading to blistering rather than the cause, since it will be recalled that removing the surface of "blistering" iron by pickling was as efficacious as machining, though the pickled surface was extremely rough and the machined surface smooth. 


\section{GAS FROM IRON AND ENAMEL HEATED IN AIR}

In the fourth series of gas evolution tests the iron specimens, coated with ground coat enamel and dried as in the preceding series, were heated in $\mathrm{CO}_{2}$-free air for 20 minutes at $875^{\circ} \mathrm{C}$. $\left(1,605^{\circ} \mathrm{F}\right.$.). The $\mathrm{CO}_{2}$ equivalents of the total oxidized carbon in this series were less for all the irons than in the series of uncoated irons heated in air but remained in the same relative order as in the earlier series in air. (See Table 22.)

TABLE 22.-Gas evolved from cast-iron specimens coated with ground enamel and heated in air

\begin{tabular}{|c|c|c|c|}
\hline Iron & Heat & $\begin{array}{l}\mathrm{CO}_{2} \text { equiv- } \\
\text { alent of to- } \\
\text { tal oxidized } \\
\text { carbon }\end{array}$ & Weight $\mathrm{H}_{2}$ \\
\hline 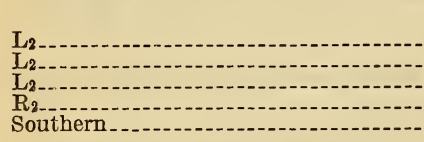 & $\begin{array}{r}1-55 \\
2-55 \\
4-55 \\
2-56 \\
41\end{array}$ & $\begin{array}{l}g \\
0.012 \\
.011 \\
.009 \\
.010 \\
.011\end{array}$ & $\begin{array}{l}0 \\
0.0001 \\
.0001 \\
\text { Nil. } \\
\text { Nil. } \\
\text { Nil. }\end{array}$ \\
\hline
\end{tabular}

The specimens from the series given in Table 22 were then coated with the standard cover coat enamel in amounts equivalent to $23 \mathrm{~g}$ per 18 square inches of surface, dried, and then heated as before in the tube furnace. This heating was for 12 minutes at $800^{\circ} \mathrm{C} .\left(1,470^{\circ} \mathrm{F}\right.$.). Very small amounts of oxidized carbon were evolved during this heating and in quite the same amounts from all specimens as shown in Table 23.

TABLE 23.-Gas evolved in firing cover caat

\begin{tabular}{|c|c|c|}
\hline Iron & Heat & $\begin{array}{c}\mathrm{CO}_{2} \text { equiva- } \\
\text { lent of total } \\
\text { oxidized } \\
\text { carbon }\end{array}$ \\
\hline & $g$ & 0.003 \\
$\mathrm{~L}_{2}$ & $1-55$ & .004 \\
$\mathrm{~L}_{2}$ & .004 \\
$\mathrm{~L}_{2}$ & .005 \\
Southern & .004 \\
\hline
\end{tabular}

\section{RATE OF CARBON OXIDATION}

The data obtained in all of the preceding tests indicate that carbon oxidized from the surface of the iron specimens is the chief source of the gas evolved during the firing of ground-coat enamels of cast iron. There is little or no evidence that either moisture or the oxide constituents of the enamel take an appreciable part in this oxidation of carbon from the surface of the iron. Oxygen of the air present in the enameling furnace appears to be the oxidizing agent.

The foregoing experiments on gas evolution have referred only to the total amount of gas evolved during the firing period. It is apparent, however, that any rapid and large evolution of gas from a specimen in the early stages of burning on an enamel coat should have very little effect in forming blisters in the enamel. It is only after the enamel coat has been fused over and completely covers the surface of the iron that gas evolution will cause blisters. More probably, only the gas evolution which continues well toward the close of the firing period produces blisters which are not healed by the fused enamel. 


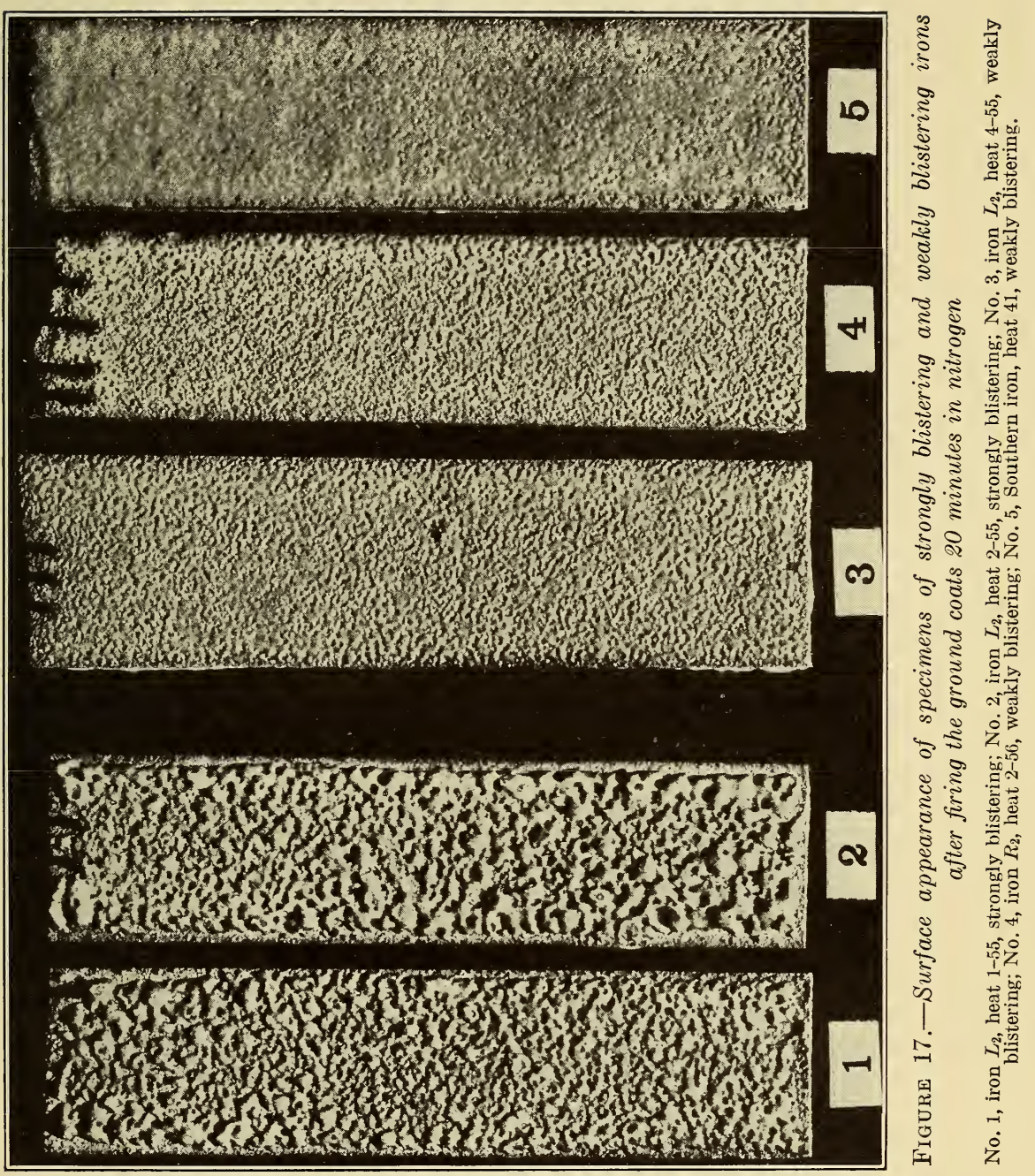




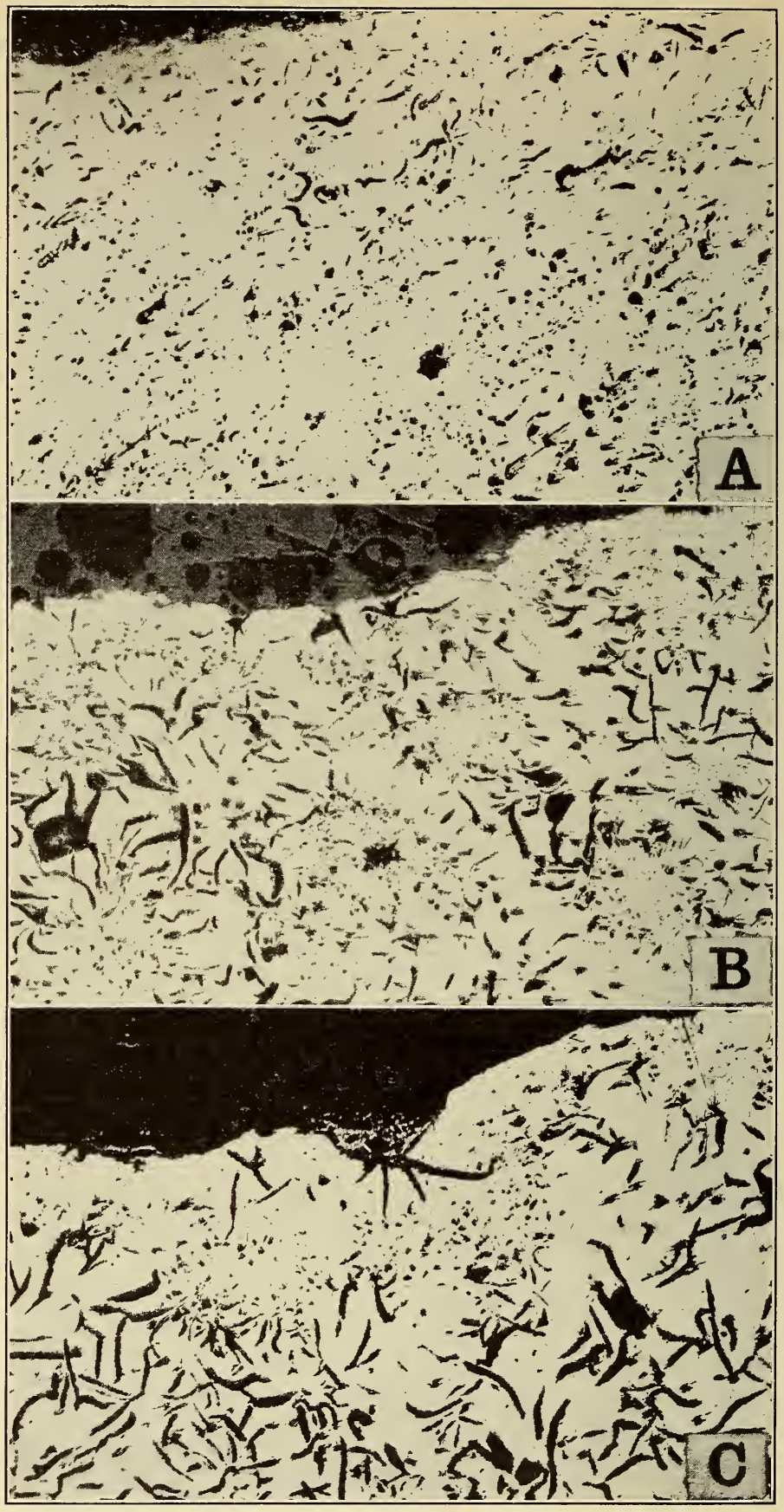

FIGURE 19.-Illustrating agglomeration of graphite particles upon enameling. Iron $R_{2}$; heat 43

Polished. $\times 100 . A$, drag side edge of cross section before enameling; $B$, specimen enameled: Ground coat fired 3 minutes at $875^{\circ} \mathrm{C}$. $\left(1,605^{\circ} \mathrm{F}\right.$.); cover coat $8 \mathrm{~min}$ utes at $800^{\circ} \mathrm{C}$. $\left(1,470^{\circ} \mathrm{F}\right.$.). No blisters were observed; $C$, specimen enameled: Ground coat fired 10 minutes at $875^{\circ} \mathrm{C}$. $\left(1,605^{\circ} \mathrm{F}\right.$ ); cover coat 8 minutes at $800^{\circ}$ C. $\left(1,470^{\circ}\right.$ F.). No blisters were observed. 
B. S. Journal of Research, RPI79

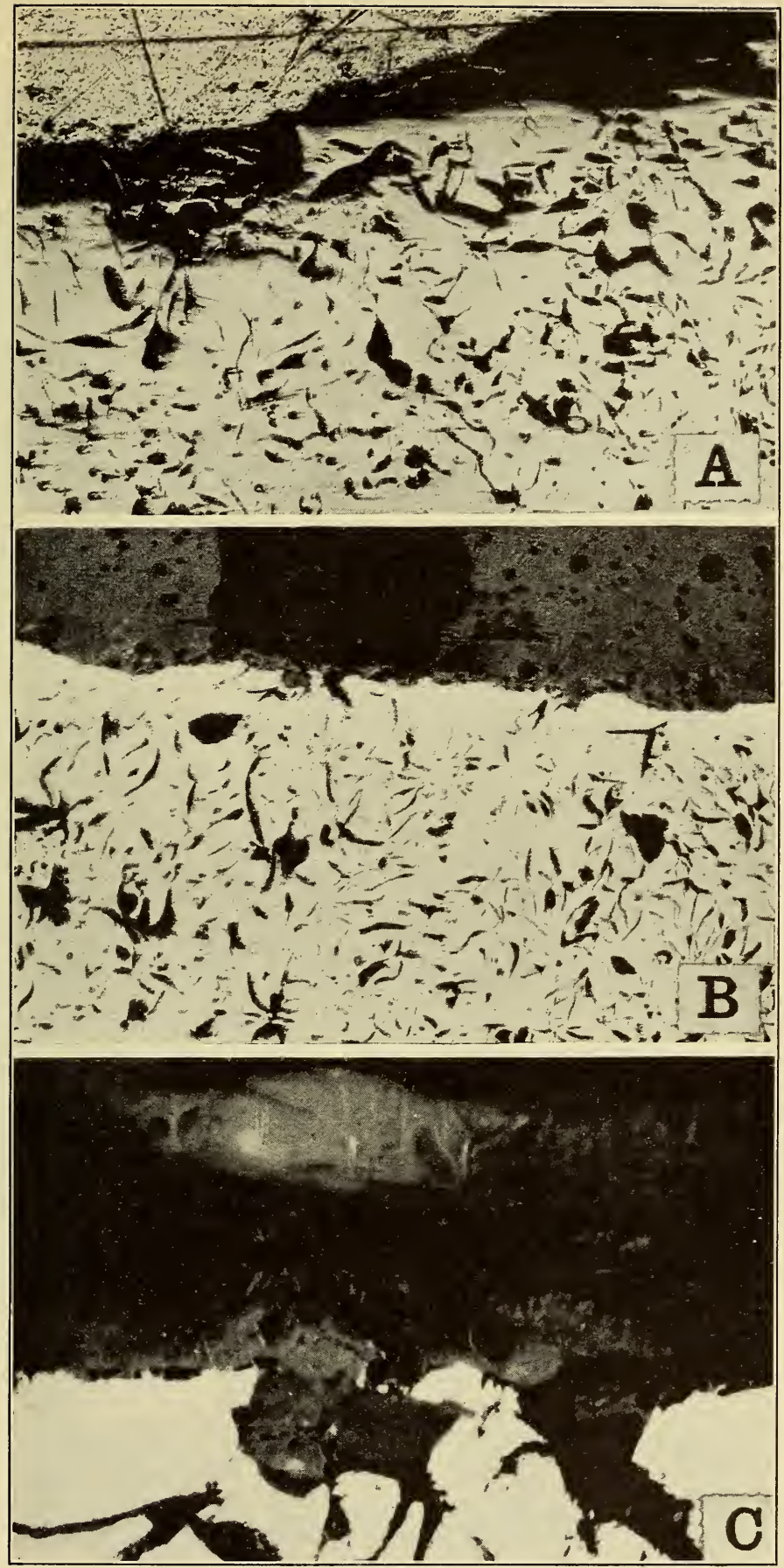

Figure 20.-Cross section of surface of blistering iron, before and after enameling. Iron $L_{2}$; heat 50

$A$, polished. $\times 100$. Drag side of cross section before enameling; $B$, polished. $\times$ 100; $C$, polished. $\times 500$; specimen thickly blistered. Ground coat fired 10 minutes at $875^{\circ} \mathrm{C}$. $\left(1,605^{\circ} \mathrm{F}\right.$.); cover coat 8 minutes at $800^{\circ} \mathrm{C}$. $\left(1,470^{\circ} \mathrm{F}\right.$.). 
In order to throw light on the relative rates of gas evolution (that is, carbon oxidation) from irons at the various stages of the enamel firing period, the following experiment was made: Strips of the typical strongly blistering iron, $1-55$, and of the three weakly blistering irons, $2-56,4-55$, and southern 41 , were cleaned by the usual sandblast procedure, sprayed with the standard ground-coat enamel,

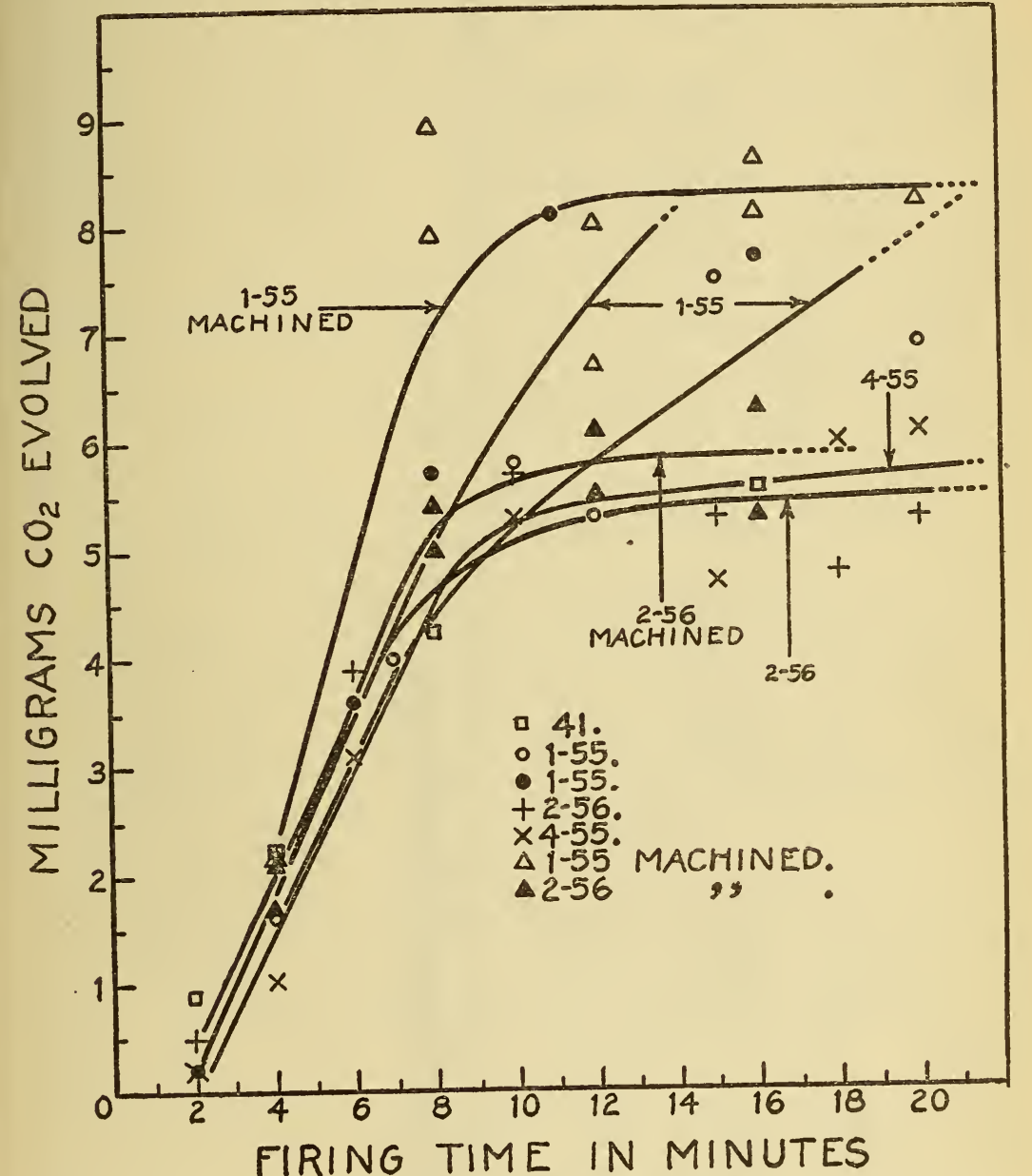

FIGURE 18.-Weight of evolved $\mathrm{CO}+\mathrm{CO}_{2}$ (calculated to $\mathrm{CO}_{2}$ ) plotted against firing periads

All specimens completely coated with ground coat and fired at $875^{\circ} \mathrm{C}$. $\left(1,605^{\circ} \mathrm{F}\right.$ ) in $\mathrm{CO}_{2}$-free All specimens completely coated with ground caat and fired at $870^{\circ}$. (1,605ical determination. atmosphere. Fach point represents one specimen and the corresponding analytical determination. weakly blistering ones.

dried and fired for varying periods of time up to a total of 20 minutes. The evolved oxides of carbon were determined in the manner previously described. The results are given in Table 24 and in Figure 18.

From this figure, it is evident that the amount of carbon oxidized and the rate of oxidation were nearly the same for all the weakly blistering irons and for the two series of tests with $\mathrm{L}_{2}, 1-55$ (the strongly blistering iron) up to a firing time of about 8 to 10 minutes. 


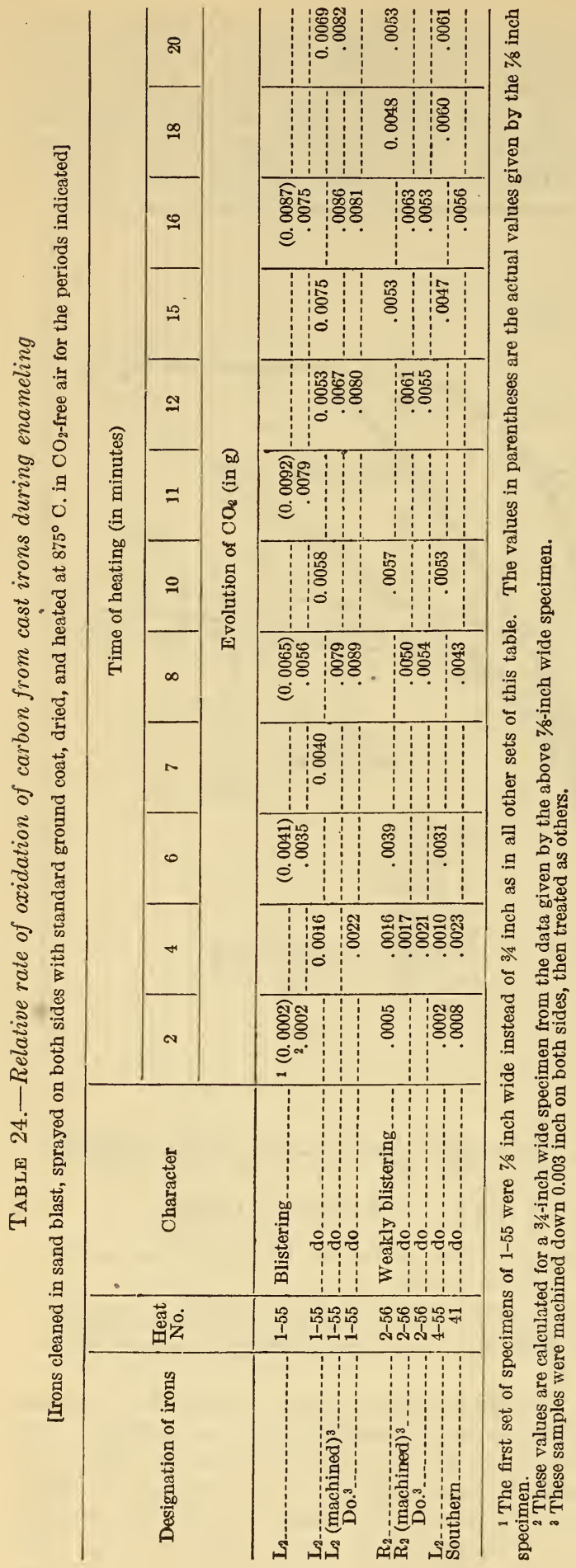


At the 8 to 10 minute firing period, however, the rate of carbon oxidation fell off very noticeably with all three ${ }^{3}$ of the weakly blistering irons and there was almost no evolution of gas (oxidized carbon) from these irons from 10 or 12 minutes to the 20 -minute limit of the firing periods of this test. Gas evolution practically ceased over that portion of the enamel firing period during which it would naturally be expected to cause blistering.

Of course, the whole cycle might be completed in a much shorter time in a furnace of greater heat capacity. Furthermore, it should be borne in mind that the first part of this period corresponds approximately to firing the ground coat, and the latter part to the additional heating that is necessary in firing the cover coat. It is during the latter part of this second period that it is important for gas evolution to be kept at a minimum. The two curves for the duplicate experiments with iron $\mathrm{L}_{2}, 1-55$, the badly blistering iron, show no decrease in rate of carbon oxidation at the point where the curves for the weakly blistering irons fiatten out, but indicate a continuing evolution of oxidized carbon practically to the end of the firing period used. Whether or not the curves flatten out here is not certain in the absence of additional points beyond the 20 -minute firing period. The question arose as to whether the curves, which flatten out at the 8 to 10 minute period, might begin to rise again if heating were continued, as, for instance, in the application of three or more coats of enamel. While the tests (fig. 18) were not carried beyond 20 minutes in any case, the fact that blisters seldom occur on reenameling castings, which may have blistered in the first enameling, seems to indicate that such a secondary rise in the gas-evolution curve, if it does take place, does not begin soon enough to give trouble in practical enameling.

The above data on the rate of carbon oxidation from the surface of enamel-coated cast-iron specimens all relate to iron cleaned by the normal sand-blast procedure. It will be recalled that machining a 0.003-inch layer from the surface of a strongly blistering iron strikingly reduced the tendency to blister.

If the cessation of oxidation of carbon relatively early in the firing period is the controlling characteristic of nonblistering irons, as is indicated by the curves for sand-blast cleaned irons in Figure 18, then a blistering iron, from the surface of which a 0.003-inch layer has been machined, might be expected to behave similarly. Specimens of $L_{2}, 1-55$, and $R_{2}, 2-56$, were machined in this way, lightly sand-blasted, and then treated exactly as the regularly sand-blasted specimens of the same irons had been treated, to determine the rate of carbon oxidation. The data on $\mathrm{CO}_{2}$ evolution from the machined specimens are given in Table 24 and are plotted in Figure 18.

These curves show that machining off the surface of iron $R_{2}$, $2-56$, had no influence on the rate of carbon oxidation from its surface nor on the point at which oxidation of carbon ceases. Machining off the surface of $\mathrm{L}_{2}, 1-55$, however, noticeably increased the rate of carbon oxidation during the first 8 minutes of the firing period, but at the 8 to 10 minute point the evolution of oxidized carbon practically ceased.

${ }^{2}$ A curve for southern iron 41 has not been drawn in Figure 18, since for that iron only one value for $\mathrm{CO}_{2}$ evolution was obtained between the 4-minute and the 16-minute firing periods. The points for this iron are given in the figure and indicate that the curve for this iron would not differ greatly from those for the other weakly blistering irons. 
10. CORRELATION OF GAS EVOLUTION DATA WITH PREVIOUS DATA

It was found possible to distinguish between strongly blistering and weakly blistering irons on the basis of the breadth of the range of firing periods within which enameling could be accomplished with relative freedom from blisters. If an iron has a sufficiently strong blistering tendency, this range will be so narrow that it is virtually nonexistent, as in the case of iron $\mathrm{L}_{2}, 1-55$ (Table 9). An iron having a somewhat weaker blistering tendency, as $\mathrm{L}_{2}, 3-55$, in the same table, gave much better results at $7 \frac{1}{2}$, and even at 10 minutes of firing the ground coat, than at the longer periods, while with iron $R_{2}, 2-56$, the range was so broad that the results were still moderately good at the 15 to $17 \frac{1}{2}$ minute periods. In all cases, however, the average results at 3 minutes were unsatisfactory. The question arises as to just how these facts fit in with the foregoing data on gas evolution.

In the first place, it is obvious that the amount of blistering will be controlled by the rate of gas evolution during that part of the firing process in which the cover coat is able to entrap the evolved gas; that is, after it has begun to fuse. With this fact in mind, it can be readily seen that when the firing period of the ground coat is very short, then (fig. 18) blisters should be expected to appear on even the best irons studied, since the cover coat will be fired while gas is still being evolved just as rapidly as from a strongly blistering iron.

In the case of the specimens which are fired longer, there are three factors to take into consideration. One is, of course, the steepness of the gas-evolution curve during the critical period; another is the degree of permeability of the ground coat, which increases as the firing period increases, and the third is the time-lag factor which influences the actual progress of the gas bubbles through the comparatively thick cover coat.

With any specific firing treatment, the number and character of blisters will depend upon the rate of gas evolution during the critical part of the firing period. An iron in which this rate is intermediate will give comparatively good results within a narrow range at the shorter firing periods because the comparative impermeability of the ground coat and the time necessary for the evolved gas to work its way through the cover coat combine to delay the actual appearance of blisters at the surface of the specimen. If the ground coat is fired longer on an exactly similar specimen, it will not be impermeable enough to prevent the appearance of blisters during the firing of the cover coat. This explanation would be applicable to iron $\mathrm{L}_{2}, 3-55$ (Table 9).

An iron in which the gas evolution is sufficiently copious during the critical period will give numerous blisters even at the most favorable firing period, although the effect of the lower permeability of the ground coat at this period is appreciable. Iron $\mathrm{L}_{2}, 1-55$, typifies this case (Table 9).

If gas evolution has practically ceased before the cover coat is fired, the added permeability of the ground coat at the longer firing periods has but little effect, though its overfired condition may be partially responsible for such blisters as do appear. Such an iron may be said to have a broad firing range. This case is typified by iron $\mathrm{R}_{2}, 2-56$ (Table 9). 
B. S. Journal of Research, RP179

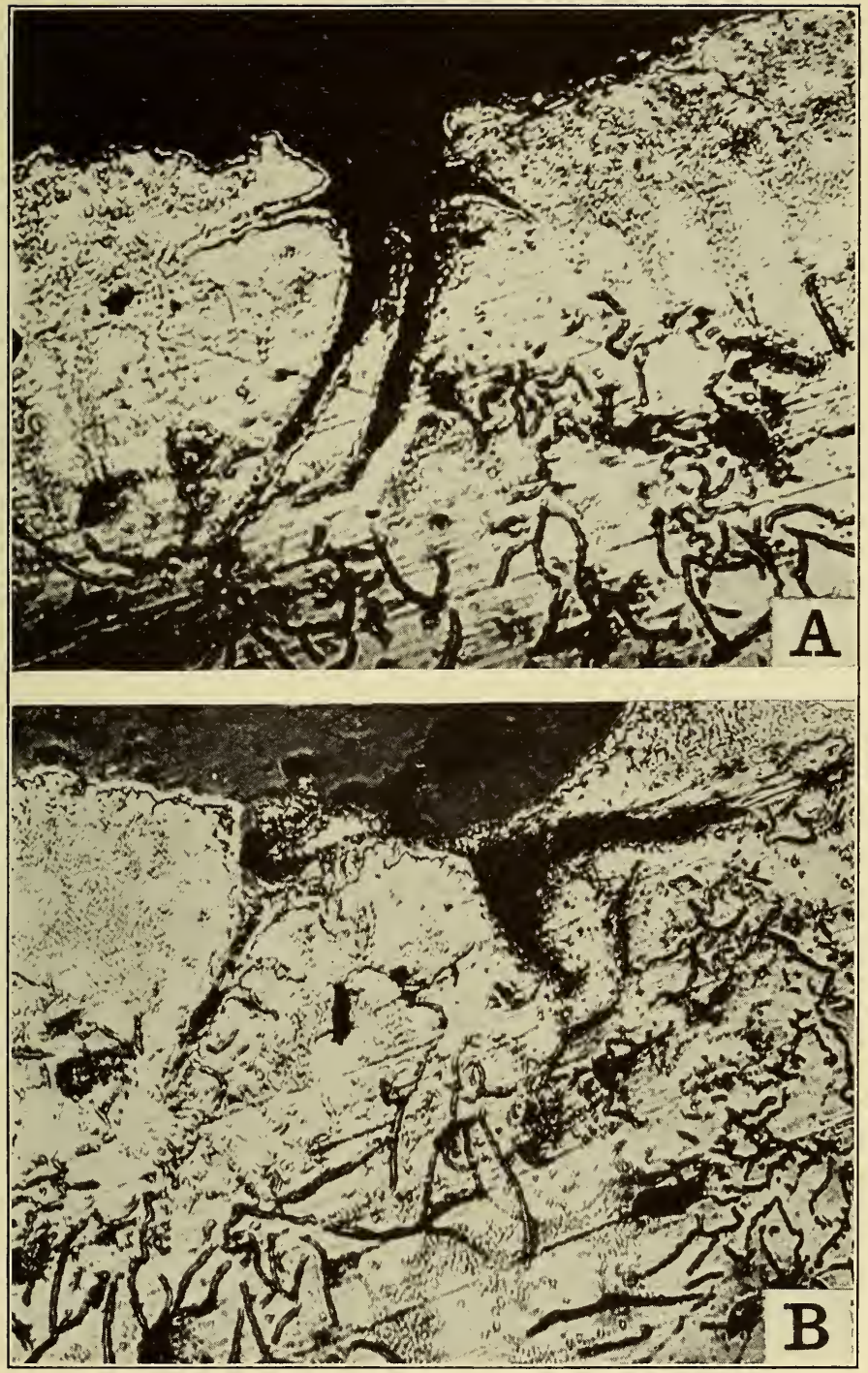

Figure 21.-Etched cross section of surface of same iron shown (polished) in Figure 20

Etched in 2 per cent $\mathrm{HNO}_{3}$. $\times 500 ; A$ and $B$ taken after enameling. 


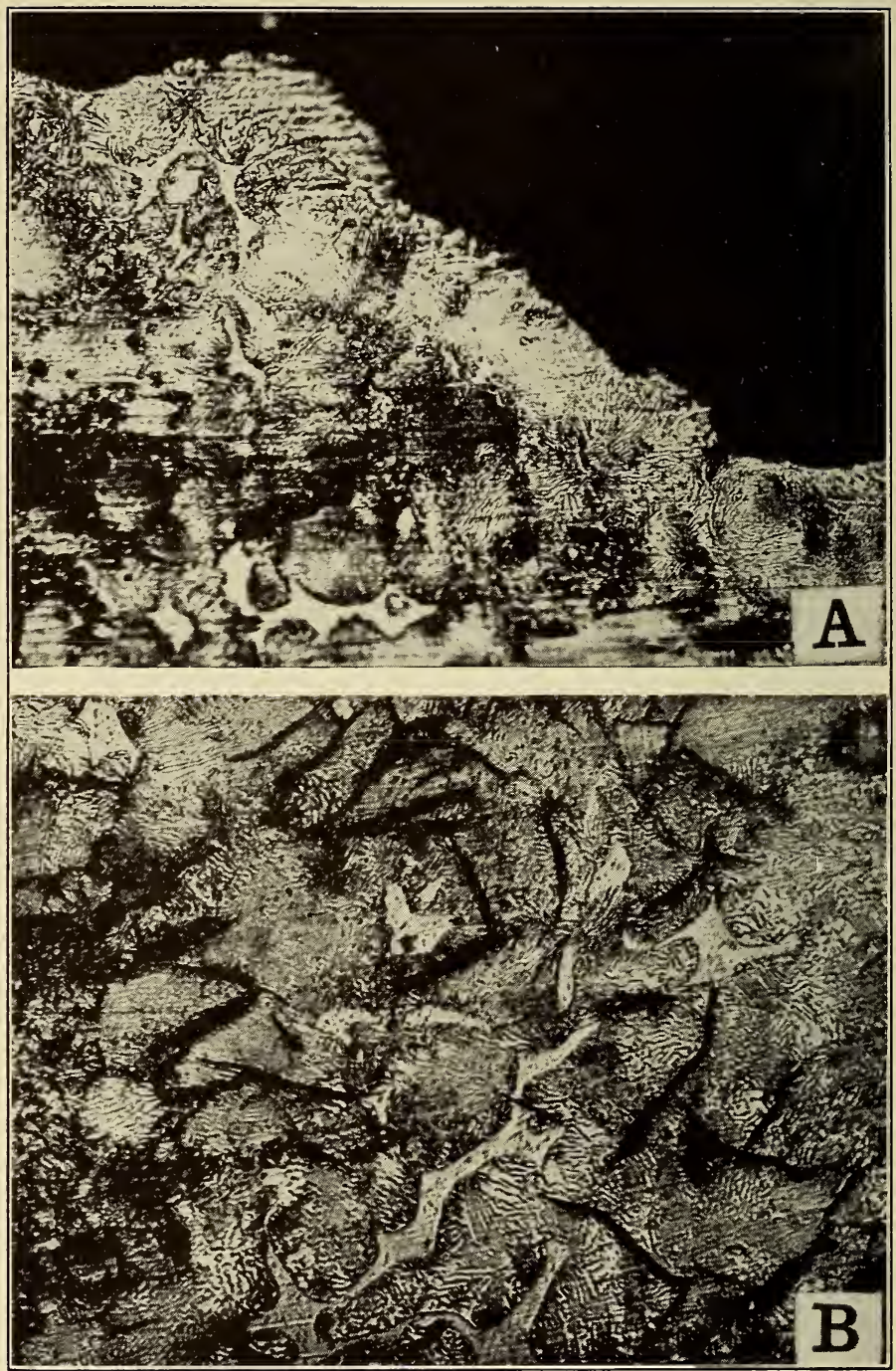

FIGURE 22.-Cross sections at surface and interior of blistering iron before and after enameling. Iron $L_{1}$; heat 16

Before enameling, etched in 5 per cent picric acid. $\times 500 ; A$, surface layer at drag side; $B$, spot near center of casting. 


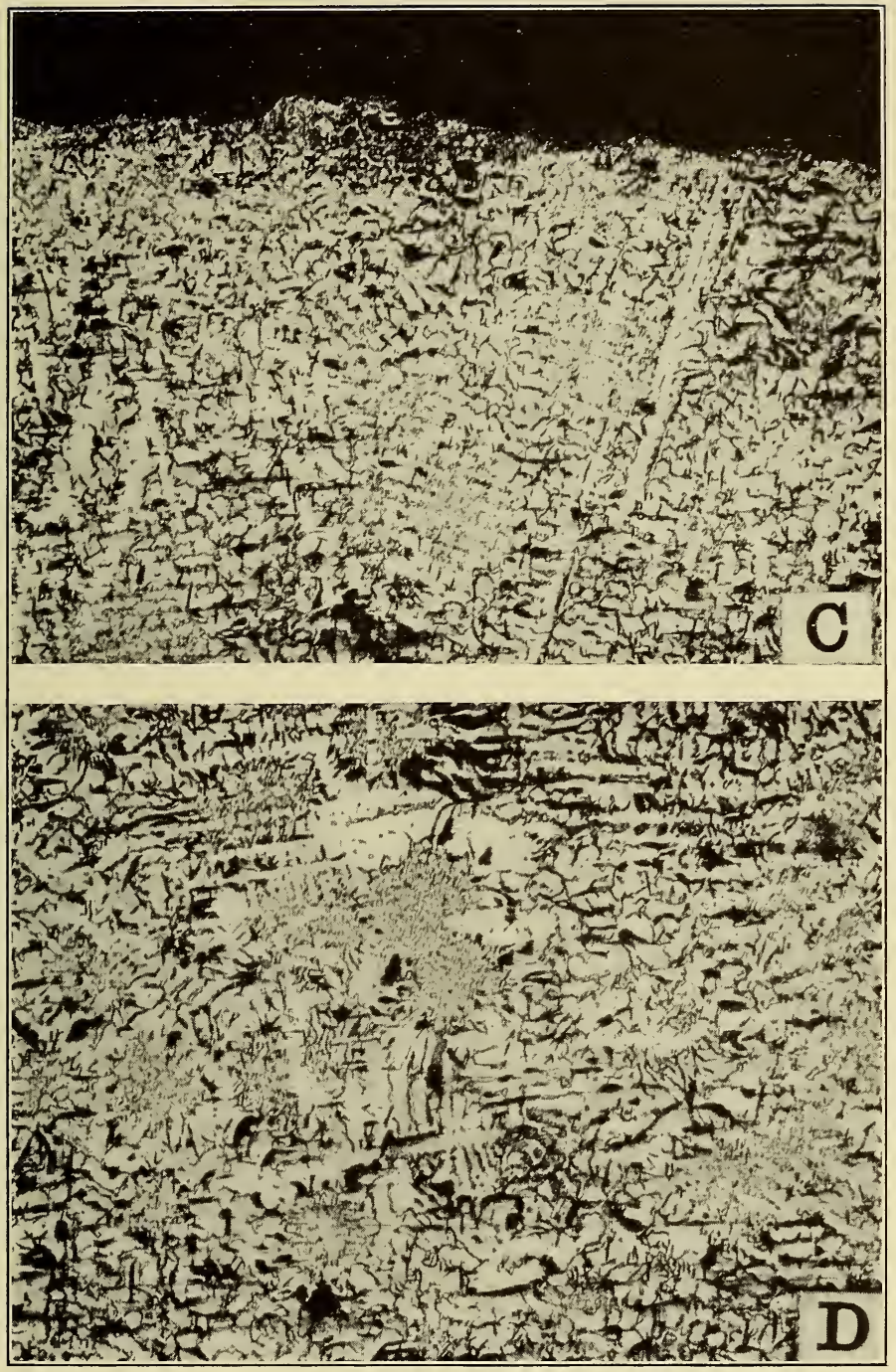

FIgURE 22.-Cross sections at service and interior of blistering iron before and after enameling. Iron $L_{1}$; heat 16 -Continued

After enameling. Etched in 5 per cent picric acid. $\times 100 ; C$, part of cross section adjacent to enamel; $D$, central part of cross section. A number of blisters were observed on this specimen. Ground coat fired 8 minutes at $870^{\circ} \mathrm{C}$. $\left(1,600^{\circ} \mathrm{F}\right.$.) and cover coat 7 minutes at $840^{\circ} \mathrm{C}$. $\left(1,545^{\circ} \mathrm{F}\right.$.). 

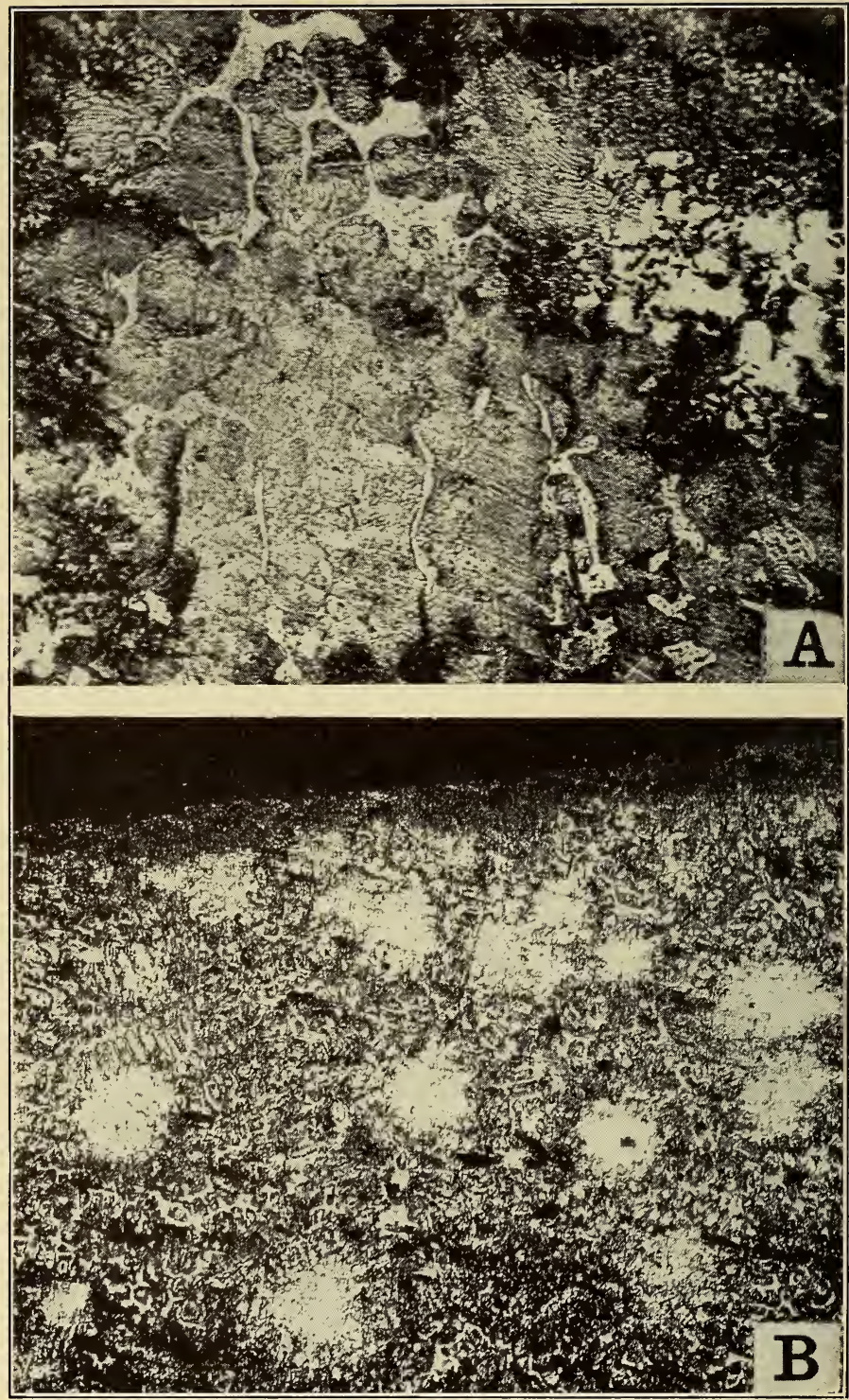

FIGURE 23.-Cross sections of surface layer of nonblistering iron before and after enameling

Carbon, 3.46 per cent; graphitic C, 2.85 per cent; combined C, 0.61 per cent; manganese, 0.52 per cent; phosphorus, 0.510 per cent; sulphur, 0.101 per cent; silicon, 2.22 per cent; etched in 5 per cent picric acid. $A$, Specimen before enameling. $\times 500$; $B$, specimen enameled. $\times 100$. No blisters were noticed on this specimen. Ground coat fired $5 \frac{1}{2}$ minutes at $900^{\circ} \mathrm{C}$. $\left(1,650^{\circ} \mathrm{F}\right.$.) ; cover coat fired 6 minutes at $840^{\circ}$ C. $\left(1,545^{\circ} \mathrm{F}\right.$.). 


\section{STUDY OF CARBON IN THE MICROCHILLED SURFACE}

All of the tests described above serve to indicate, if not to prove, that the blister-forming gas is not $\mathrm{SO}_{2}$, hydrogen from the decomposition of steam, or nitrogen from the decomposition of iron nitride. In all probability, it is $\mathrm{CO}_{2}$ and $\mathrm{CO}$.

There is good evidence that the reactivity of different varieties of carbon and graphite varies very greatly with the ratio of surface to volume of the particles, and with the mode of formation of the particles. Falcke (26), for example, experimented with the rate at which amorphous carbon purified in various ways and purified natural graphite from different sources, reduced iron oxide in the presence of iron. The initial temperature at which reduction started and the rate at which it progressed varied markedly with the different varieties of 'carbon and graphite.

Moreover, the $\mathrm{CO}$ and $\mathrm{CO}_{2}$ formed by the oxidation of any form of carbon will affect the rate of decomposition of cementite both by decarburization (27), which alters the amount of carbon, and hence its distribution between the graphitic and combined forms, and, according to Hayes (28), by a catalytic action.

It has been noted in commercial enameling that adhesion of enamel, for which a certain degree of oxidation of the surface of the iron is thought to be desirable, varies according to the size of the load with respect to the size of the furnace. This may indicate that there is not always enough oxygen available in the furnace atmosphere effectively to oxidize a large surface of graphite particles.

The weight of evidence strongly indicates that carbon in some one or more of the possible forms, ordinary graphite, submicroscopic graphite, "temper carbon," or combined carbon (cementite) plays a major rôle in the formation of blisters, and the problem appears to resolve itself into a study of carbon in the microchilled surface.

\section{ORDINARY GRAPHITE}

It is unlikely that massive graphite is responsible for blistering. It is true that finely divided graphite smeared on the surface of the iron as by writing on the iron with a pencil gives blisters, and that carbonaceous mold facings are probably to be avoided, though very light applications have been successfully used.

One might assume that in severe sand-blasting, which is known to minimize blistering, the graphite flakes may be dug out and removed, and leave a practically graphite-free surface. Microscopic examination, however, shows that graphite flakes may extend to the surface of the metal without causing blisters. (Fig. $19(c)$.) On the other hand, graphite flakes may appear at the surface of a specimen which does blister. (Figs. 20 and 21.) Such flakes may cause local poor adherence of the enamel. However, poor adherence does not seem to be necessarily connected with blistering, which fact is illustrated in Figure 16.

Moreover, as Figure 9 shows, a machined surface of the blistering iron $\mathrm{L}_{2}$ does not blister, and it is certain that machining does not drag out and remove all the graphite flakes. Massive graphite in itself can not be considered as invariably producing blisters. 


\section{SUBMICROSCOPIC GRAPHITE}

The assumption was made that aside from the regular graphite particles, visible under high and low magnification, there are particles beyond the resolution of the microscope. On account of their small size, these particles should be very active and should readily respond to the heat; that is, they may agglomerate to somewhat larger groups or may burn away, depending upon the temperature used.

A certain confirmation of these data is given in the following statement by Ropsy (17); "In fact, in the hardened part of a chilled casting (cooled, therefore, very rapidly and solidified almost without transformation) there remains up to 0.15 per cent of carbon in the form of graphite. To effect this determination with precision, at least $5 \mathrm{~g}$ of metal must be dissolved, the determination of graphite being carried out on the residue. The microscope, even with the highest magnification, does not show this graphite, probably because it is disseminated throughout the mass in the form of particles which are too minute."

If these particles are, in fact, disseminated "throughout the mass," it is obvious that they could cause the evolution of gas even after the removal of the surface layer of a casting and may be responsible for a large evolution of gas in the first period of firing.

In fact it is probable that the comparatively rapid evolution of gas during the first 8 to 10 minutes of firing (fig. 18) is in all cases caused by the oxidation of these submicroscopic particles of graphite, which are presumed to be present in approximately equal concentration $(a)$ in the surface layer of the weakly blistering iron, $(b)$ beneath the surface of the weakly blistering iron, and $(c)$ in the surface layer of the strongly blistering iron, but in greater concentration beneath the surface of the strongly blistering iron. In all cases the oxidation of this type of carbon is probably completed in the 8 to 10 minute period, and is not responsible for any subsequent evolution of gas.

\section{COMBINED AND TEMPER CARBONS}

As pointed out in the introduction, chilled iron, with practically all of the carbon in the combined form, has been said by some to blister and by others not to blister. It was thought that the explanation of this difference of opinion might lie in the individual conditions surrounding each observation, which in some cases tend to promote and in others to retard graphitization. These conditions are believed to include the degree of massiveness of the cementite formation, the presence or absence of elements which tend to stabilize cementite, superheating of the melt and other conditions. In order to throw some light on this question, the following experiments were carried out.

Samples of a white iron (plow shares) ${ }^{4}$ were subjected to the standard enameling tests, and were found to blister badly over the whole range of firing temperatures. Specimens from which the surface had been deeply machined still blistered just as badly.

On annealing this white iron at $950^{\circ} \mathrm{C}$. $\left(1,740^{\circ} \mathrm{F}\right.$.) for five hours and cooling in the furnace, the tendency to blister was much reduced, the specimen tested at the shorter firing periods of the "range" method being practically perfect. The surface was decarburized by

4 Donated by The Lynchburg Foundry Co., Lynchburg, Va. 
the long heating. However, specimens from which the decarburized surface had been removed by machining, so that the enamel was applied on a surface that was not decarburized, were equally as good as those enameled on the decarburized surface. Such long annealing was not required since heating to $900^{\circ} \mathrm{C}$. $\left(1,650^{\circ} \mathrm{F}\right.$.) for 45 minutes followed by furnace cooling, was also effective in greatly diminishing blistering.

The annealing altered the structure decidedly by producing well agglomerated "temper carbon," that is, practically massive graphite. In the short heating of the enameling process, there was evident decomposition of cementite, but very little agglomeration. On the other hand, a specimen of malleable iron in which microscopic examination showed most of the "temper" carbon to be well agglomerated did not blister (rating 1 ) when the firing time of the ground coat was $7 \frac{1}{2}$ or 10 minutes, but did blister badly (rating 4 to 5 ) at $12 \frac{1}{2}$ and 15 minutes. Well agglomerated temper carbon thus appears nearly as nonreactive as massive graphite. The distinction between agglomerated temper carbon of malleable iron and massive graphite of gray iron is, therefore, probably one of appearance rather than of chemical activity.

The great activity of colloidally dispersed temper carbon, just as it forms and before it agglomerates is in sharp distinction to the lower activity of the agglomerated material.

In order to study a mild chilling effect on the weakly blistering castings, iron $R_{2}$ was cast in the usual three-sixteenths inch thick plates in a variety of sand molds as follows: $(a)$ Skin dried; $(b)$ moisture content, 6 to 7 per cent; $(c)$ moisture content, 10 per cent. This heat was designated No. 65 .

The specimens were enameled in the regular way save that the time of firing of the ground coat was $12 \frac{1}{2}$ minutes instead of 8 as heretofore, since the longer time of firing seemed to accentuate the tendency to blister. All specimens were graded No. 2 with respect to blistering. These results indicated that the variations in moisture content of molding sand used were not pronounced enough to cause chilling sufficient to affect the blistering tendency.

Some interesting results were obtained when definite chilling of the surface was resorted to. Strongly blistering iron $\mathrm{L}_{2}$ and weakly blistering iron, $R_{2}$, were cast in blocks 3 by 6 by 2 inches in various ways, $(a)$ in green sand, (b) against a chill plate covered by one-fourth inch of green sand, and (c) directly against a chill. Slices three-sixteenths inch thick were then cut from the blocks, the slice from the drag side being designated $\mathrm{A}$ and the next three-sixteenth-inch slice, B. The surfaces enameled were the drag face on A and on B the surface three-sixteenths inch from the drag side. The standard enamel with $12 \frac{1}{2}$-minute firing of the ground coat was used. The results are given in Table 25.

TABLE 25.-Enamel ratings of iron specimens with chilled surfaces

\begin{tabular}{|c|c|c|c|c|c|}
\hline \multirow[b]{2}{*}{ Specimen } & \multirow[b]{2}{*}{ Iron } & \multirow[b]{2}{*}{ Character of iron } & \multicolumn{3}{|c|}{ Enamel ratings } \\
\hline & & & $\begin{array}{l}\text { Green } \\
\text { sand }\end{array}$ & $\begin{array}{c}\text { Sand over } \\
\text { chill } \\
\text { plate }\end{array}$ & $\begin{array}{l}\text { Chill } \\
\text { plate }\end{array}$ \\
\hline A.-. & $\left\{\begin{array}{l}\mathrm{L}_{2} \\
\mathrm{R}_{2} \\
\mathrm{~L}_{2} \\
\mathrm{R}_{2}\end{array}\right.$ & $\begin{array}{l}\text { Strongly blistering } \\
\text { Weakly blistering } \\
\text { Strongly blistering } \\
\text { Weakly blistering- }\end{array}$ & $\begin{array}{r}4-5 \\
1-2 \\
2 \\
2\end{array}$ & \begin{tabular}{r|r}
$4-5$ \\
4 \\
2 \\
2
\end{tabular} & $\begin{array}{r}4-5 \\
2-3 \\
2 \\
4-5\end{array}$ \\
\hline
\end{tabular}

$106307^{\circ}-30-5$ 
Consider first the results in green sand. It will be noted that away from the surface, the body of the strongly blistering iron gives good enamel ratings. This is the equivalent of an ordinary strongly blistering test plate from which the microchilled surface has been machined. The weakly blistering iron behaves the same at the surface and in the interior, which observation is consistent with Figure 9.

When the surface was slightly chilled, by casting against one-fourth inch of green sand over a chill plate, the iron termed as "weakly" blistering took on a casting surface that was as poor as that of the iron termed "strongly" blistering. Removal of the surface produced the same improvement in both. Under such casting conditions the irons were identical in behavior as to blistering. Irons $R_{2}$ and $L_{2}$ did not appear very different in nature.

When the surface was more strongly chilled by casting directly against a chill plate, the strongly blistering iron acted just as it did with less severe chilling. However, the weakly blistering iron had less blistering tendency on the strongly chilled surface than it had on the corresponding weakly chilled surface (slice A, Table 25). In the interior, however (three-sixteenth inch from the drag surface) the severely chilled weakly blistering iron behaved on enameling practically the same as the drag side of the same when less severely chilled.

The decomposition of cementite from combined carbon to temper carbon or graphite which occurs in a chilled or microchilled layer during enameling will doubtless depend on $(a)$ the original conten $t$ of combined carbon, $(b)$ the composition of the iron as to elements that promote or hinder graphitization, and $(c)$ the time and temperature of enameling.

If all these conditions are such that there is no breakdown of combined carbon during enameling, it may be assumed that the iron does not blister. Under this assumption, either stable white iron, or stable gray iron would be "nonblistering." But, if the chilled layer contains combined carbon that does break down to colloidally dispersed temper carbon during a certain period of the enameling process, it will blister. If the enameling process is carried out at a high temperature and for a long time (for example, 15 or $171 \frac{1}{2}$ minute firing periods), the blistering tendency will be accentuated either because the combined carbon, although stabilized, may begin to break down under this treatment or because the graphite may begin to oxidize under such conditions. If the same iron is enameled with a shorter firing period, or at a lower temperature, or by using more fusible enamels, the iron may not blister.

Thus, the blistering for which combined carbon is responsible may be traced to the breakdown of combined carbon to temper carbon at a stage during enameling at which oxidation can occur and at which the enamel is in such physical condition as to retain the $\mathrm{CO}$ and $\mathrm{CO}_{2}$ formed. If the breakdown at this stage is prevented, there will be no "nascent" temper carbon to cause blisters. It may be prevented by the nature of the chilled layer itself, or by removing the offending surface layer, or avoiding conditions that will produce this layer, or decarburizing the surface, or by accomplishing the breakdown before the enameling operation.

To recapitulate, stable cementite is not necessarily readily oxidized to give the $\mathrm{CO}_{2}$ or $\mathrm{CO}$ gases that appear to be responsible for blistering. Neither does massive graphite, whether formed as such during 
solidification and cooling of gray iron, or as a product of decomposition of cementite on annealing, appear responsible for blistering. It does appear, however, that an intermediate structure, resulting from the partial breakdown of cementite on annealing and partial agglomeration to graphite is the most active in producing blisters.

The enameling process itself is a short anneal. The decomposition of cementite will be accelerated by the presence of graphite in the original casting. Agglomeration of small, widely distributed particles of primary graphite into larger flakes is shown by Figure $19(a),(b)$, (c), in which the progressively increased agglomeration of graphite particles with increased firing periods is very plain. Even the body of a gray-iron casting is changed in structure and hardness by the heat-treatment incidental to enameling.

\section{CHANGE OF HARDNESS AND STRUCTURE ON ENAMELING}

Table 26 shows the decrease in hardness that takes place on enameling. Metallographic examination of a number of specimens showed that a considerable change in the structure of the iron occurred during the enameling process and this change often was not confined to the surface layer, but took place throughout the section of the specimens. A specimen.which before enameling contained a lamellar pearlite matrix throughout its section (figs. $22(A)$ and $(B)$ ), showed, after enameling, the large ferritic areas and dendritic structure similar to those represented in Figures $22(C)$ and $(D)$. The remainder of the pearlite was usually spheroidized or changed to sorbite.

It was noted that some specimens of weakly blistering iron appeared to undergo no change detectable under the microscope during enameling. Figure $23(B)$ at $\times 100$ shows a weakly blistering specimen, the suriace of which when examined at $\times 500$ after enameling appeared to be unchanged from the pearlitic structure of the unenameled specimen shown in Figure $23(A)$. It was thought for a time that a lower blistering tendency might be associated with a smaller change in structure, but it was found later that this was not always true and that a marked change in structure often occurred in weakly blistering as well as in strongly blistering specimens.

Much attention was paid to the "habit" of the graphite (17); that is, whether it was in fine flakes, only slightly agglomerated, or almost entirely agglomerated in the "whirl" form, but the observations seemed to justify the conclusion that the habit of the graphite is not definitely associated with the blistering tendency.

\section{BURNING OUT}

The familiar "burning out" or normalizing in air so often resorted to by the enameler to prevent blistering may be considered as accomplishing various things: (a) It removes some of the surface layer of metal by oxidation, $(b)$ it tends to decarburize, and hence, soften the layer of metal immediately beneath the oxide coat; $(c)$ it softens the metal as a whole. Hence, when a "burned-out" casting is sandblasted, the loose oxide comes off readily, and the surface, now softer than before annealing, is more readily removed by sandblasting. 
TABLE 26.-Change in hardness of iron during enameling

\begin{tabular}{|c|c|c|c|c|c|c|c|c|c|}
\hline \multirow{2}{*}{ Iron } & \multirow{2}{*}{ Melts } & \multirow{2}{*}{$\begin{array}{l}\text { Heat } \\
\text { No. }\end{array}$} & \multicolumn{3}{|c|}{ Carbon } & \multirow{2}{*}{ Mn } & \multirow{2}{*}{$\mathbf{P}$} & \multirow{2}{*}{$\mathrm{s}$} & \multirow[b]{2}{*}{$\mathrm{Si}$} \\
\hline & & & Total & $\underset{\text { ite }}{\text { Graph- }}$ & $\begin{array}{l}\text { Com- } \\
\text { bined }\end{array}$ & & & & \\
\hline & & & Per cent & Per cent & Per cent & Per cent & Per cent & Per cent & Per cent \\
\hline $\mathrm{L}_{1}$ & Cupola_-.--.--..- & 6 & 3.65 & 2.97 & 0.68 & 0.56 & 0.46 & 0.05 & 2.16 \\
\hline $\mathrm{L}_{1}$ & Cupola, melted 3 times & $\begin{array}{l}14 \\
16\end{array}$ & $\begin{array}{l}3.47 \\
3.47\end{array}$ & $\begin{array}{l}3.07 \\
2.95\end{array}$ & $\begin{array}{l}.40 \\
.52\end{array}$ & $\begin{array}{l}.57 \\
.33\end{array}$ & $\begin{array}{l}.46 \\
.47\end{array}$ & $\begin{array}{l}.076 \\
.095\end{array}$ & $\begin{array}{l}2.24 \\
1.92\end{array}$ \\
\hline $\mathrm{L}_{1}$ & Cupola with 0.1 per cent $\mathrm{S}$ in the & & & & & & & .121 & 2. 22 \\
\hline $\mathrm{L}_{1}$ & Electric furnace-1- & 17 & 3.76 & 3.10 & .66 & .63 & .47 & .038 & 2.19 \\
\hline $\mathrm{L}_{1}$ & Electric with 0.1 per cent $S$ in the & 20 & 3.81 & 3.09 & .72 & .65 & .45 & .10 & 2. 13 \\
\hline $\mathrm{L}_{1}$ & Electric with 0.13 per cent $S$ & & & & & & & & \\
\hline$R_{1}$ & Cupola & $\begin{array}{r}28 \\
7\end{array}$ & $\begin{array}{l}3.08 \\
3.40\end{array}$ & $\begin{array}{l}3.09 \\
3.18\end{array}$ & .22 & .69 & .81 & .048 & $\begin{array}{l}2.21 \\
2.82\end{array}$ \\
\hline $\mathrm{R}_{1}$ & $\begin{array}{l}\text { Electric with } 0.16 \text { per cent } \mathrm{S} \\
\text { added to molten iron in the }\end{array}$ & & & & & & & & \\
\hline $\mathrm{L}_{2}$ & $\begin{array}{l}\text { furnace } \\
\text { Electric }\end{array}$ & $\begin{array}{l}26 \\
44\end{array}$ & $\begin{array}{l}3.58 \\
3.60\end{array}$ & $\begin{array}{l}\text { 3. } 09 \\
\text { 3. } 15\end{array}$ & .49 & .77 & $\begin{array}{l}.79 \\
.49\end{array}$ & .09 & $\begin{array}{l}2.93 \\
2.44\end{array}$ \\
\hline \multirow[b]{2}{*}{ Iron } & \multirow{2}{*}{\multicolumn{2}{|c|}{ Melts }} & \multirow[b]{2}{*}{$\begin{array}{l}\text { Heat } \\
\text { No. }\end{array}$} & \multicolumn{2}{|c|}{$\begin{array}{l}\text { Hardness before } \\
\text { enameling }\end{array}$} & \multicolumn{2}{|c|}{$\begin{array}{l}\text { Hardness after } \\
\text { enameling }\end{array}$} & \multicolumn{2}{|c|}{$\begin{array}{l}\text { Decrease in } \\
\text { hardness }\end{array}$} \\
\hline & & & & $\begin{array}{l}\text { Shore } \\
\text { sclero- } \\
\text { scope }\end{array}$ & $\begin{array}{l}\text { Rock- } \\
\text { well B } \\
\text { scale }\end{array}$ & $\begin{array}{l}\text { Shore } \\
\text { sclero- } \\
\text { scope }\end{array}$ & $\begin{array}{l}\text { Rock- } \\
\text { well B } \\
\text { scale }\end{array}$ & $\begin{array}{l}\text { Shore } \\
\text { sclero- } \\
\text { scope }\end{array}$ & $\begin{array}{l}\text { Rock- } \\
\text { well B } \\
\text { scale }\end{array}$ \\
\hline $\mathrm{L}_{1}$ & \multicolumn{2}{|l|}{ Cupola_. } & \multirow{5}{*}{$\begin{array}{r}6 \\
14 \\
16 \\
22 \\
17\end{array}$} & \multirow{5}{*}{$\begin{array}{l}47.4 \\
48.4 \\
50.4 \\
47.3 \\
43.4\end{array}$} & 96.2 & \multirow{5}{*}{$\begin{array}{l}33.9 \\
35.7 \\
35.1 \\
36.4 \\
33.0\end{array}$} & \multirow{5}{*}{$\begin{array}{l}79.8 \\
76.8 \\
81.3 \\
81.1 \\
81.3\end{array}$} & \multirow{5}{*}{$\begin{array}{c}\text { Per cent } \\
28.5 \\
26.2 \\
30.4 \\
23.0 \\
24.0\end{array}$} & \multirow{5}{*}{$\begin{array}{r}\text { Per cent } \\
17.0 \\
17.6 \\
16.0 \\
15.1 \\
9.1\end{array}$} \\
\hline $\mathrm{L}_{1}$ & & & & & 93.2 & & & & \\
\hline $\mathrm{L}_{1}$ & Cupola, melted 3 times- & & & & 96.8 & & & & \\
\hline$I_{L_{1}}$ & Cupola with 0.1 per cent $S$ in the & adle. & & & 95.6 & & & & \\
\hline & Electric furnace...... & & & & 89.4 & & & & \\
\hline \multirow{2}{*}{$\begin{array}{l}\mathrm{L}_{1} \\
\mathrm{~L}_{1}\end{array}$} & \multirow{2}{*}{\multicolumn{2}{|c|}{$\begin{array}{l}\text { Electric with } 0.1 \text { per cent } S \text { in the ladle- } \\
\text { Electric with } 0.13 \text { per cent } S \text { charged with }\end{array}$}} & \multirow{3}{*}{$\begin{array}{r}28 \\
7\end{array}$} & \multirow{3}{*}{$\begin{array}{l}46.8 \\
46 \\
46\end{array}$} & 93.8 & 32.9 & 80.5 & 29.7 & 14.1 \\
\hline & & & & & 94.6 & 33.1 & 82.5 & 28.0 & 11.1 \\
\hline \multirow{2}{*}{$\begin{array}{l}\mathrm{R}_{1} \\
\mathrm{R}_{1}\end{array}$} & Cupola- & & & & 94.6 & 40.9 & 89.7 & 11.1 & 5.2 \\
\hline & $\begin{array}{l}\text { Electre with } 0.16 \text { per cent } S \text { a } \\
\text { molten iron in the furnace. }\end{array}$ & ded to & \multirow{2}{*}{$\begin{array}{l}26 \\
44\end{array}$} & \multirow{2}{*}{$\begin{array}{l}42.6 \\
46.5\end{array}$} & & 35.8 & & & \\
\hline $\mathrm{L}_{2}$ & Electric_-_. & & & & 93.3 & 38.5 & 75.7 & 17.2 & 19.0 \\
\hline
\end{tabular}

\section{EFFECT OF ELEMENTS IN CAST IRON ON CHILIING TENDENCY}

The formation of the microchill appears to be a matter of delicate balance, as is evidenced by Table 9, where some heats of the "strongly blistering" northern iron are shown to be better than some heats of the "weakly blistering" iron.

The question then arises, can the composition of the "blistering" irons be so adjusted that the microchill will not form, or will not be too deep and too hard for complete removal by ordinary sandblasting. In order to bring this about, it would be quite natural to add some element that would tend to foster graphitization and prevent the retention of combined carbon. The addition of silicon, aluminum, or nickel (well-known graphitizing agents) as previously discussed, indicated that some improvement may be accomplished by such means, particularly in the case of silicon if added in the proper manner and proportion. The "microchill" appears to be more difficult to prevent than the ordinary chill, which can be readily controlled by properly adjusting the composition and the rate of cooling. However, it seems reasonable that all changes that tend to prevent the formation of the ordinary chill would also be steps in 
the right direction in the prevention of the "microchill." We may, therefore, turn to a brief consideration of the effect of the various alloying elements on the chilling of cast iron; that is, the formation of combined carbon.

Gray cast iron, such as is used for enameling, contains carbon, silicon, sulphur, manganese, and phosphorus besides small amounts of other elements. The properties of the iron are very greatly affected by the condition of the carbon, and this is controlled as much by the rate of cooling as by the composition. When the metal freezes, the carbon is in combination with iron, as the compound $\mathrm{Fe}_{3} \mathrm{C}$ (cementite). Manganese, chromium, or other carbide forming elements form similar carbides, and cementite will normally be contaminated with more or less of those carbides. If the metal is chilled very rapidly, the cementite is retained without decomposition, and white or chilled iron which is practically free from graphite will result. Cementite is brittle and hard and since white cast iron contains so much cementite it is extremely brittle and hard.

If the metal is allowed to cool more slowly, during and after solidification, some of the cementite will decompose and form iron (ferrite) and free carbon (graphite or temper carbon). The resulting product, "gray iron," is much softer than white iron.

The total amount of carbon in ordinary cast irons does not vary very much, but the relative amounts of free carbon and of combined carbon (cementite) do vary greatly, not only with the rate of cooling, but also with the other elements present.

\section{(a) SILICON}

At a given rate of cooling, a higher silicon content is favorable toward a higher graphite and a lower combined carbon content. The silicon content is the chief factor controlling the ratio of graphite and combined carbon and the chief agent in securing soft gray iron instead of hard white iron.

\section{(b) PHOSPHORUS}

Phosphorus is alleged (21) to foster graphitization and thus tend to inake soft iron. But iron phosphide itself is hard and brittle so that a high phosphorus iron tends to be hard, notwithstanding the increased precipitation of graphite. The iron phosphide has a low melting point, and the fusibility of the iron is much increased by increase in phosphorus. Since the melting point is lower the pouring temperature can be lower, and hence the rate of cooling will be altered. The action of phosphorus is, therefore, complex.

(c) SULPHUR AND MANGANESE

Sulphur tends to oppose the precipitation of graphite, especially when present as iron sulphide. If sufficient manganese is present, the sulphur will be combined as manganese sulphide, which is more inert in its effect on precipitation of graphite. The ratio of manganese to sulphur therefore, governs the effect of the sulphur up to the point (often taken as $7: 1$ ) where manganese is in decided excess of the amount necessary to force practically all the sulphur into manganese sulphide. Up to this point, then, manganese is in a way a softener because of its effect on sulphur. 
Shaw (19) denies that manganese aids the retention of carbon as cementite and ascribes the increased Brinell hardness to the effect of manganese in altering the microstructure, the matrix tending to be sorbitic and the graphite in "whirl" form. Parker (22), however, insists that manganese does increase the stability of the carbide. The effect of increased sulphur in slowing down the rate of graphitization of white cast iron, and the counteracting effect due to manganese additions is brought out by Hayes and Flanders (23) and others (24).

Cupola remelting would be expected (Table 1) to lower the silicon and manganese somewhat and to raise the sulphur, with consequent decrease in the ratio of manganese to sulphur. This change is accompanied by an increase of combined carbon which causes a hardening of the iron. Cupola remelting would thus be expected to act in a detrimental manner rather than a beneficial one on blistering. No satisfactory evidence has been obtained in support of the idea that remelting was beneficial.

Manganese in excess of the amount required to combine with sulphur, however, is usually considered a hardener, which forms a stable, manganese-bearing cementite and increases the depth of chill. Guedras (25) says that in black-heart malleable castings the formation of a finely dispersed type of temper carbon rather than of large graphite particles is favored by the stabilizing action of manganese upon cementite.

The graphite precipitated from cementite as the casting cools presumably appears first as very finely divided, even submicroscopic, "temper carbon," which is chemically and structurally the same as massive graphite, but very much more finely divided, hence, much more reactive.

\section{SUMMARY}

The data obtained in this investigation support the explanation of blistering which is summarized in the following paragraphs, and which is the only one known to the authors that fits the facts so far observed.

1. There is ample evidence that physical defects, especially "sponginess," will give rise to blisters. Moreover, an enamel may be composed, prepared, or applied in such a manner as to cause blisters irrespective of the character of the iron used. There are, however, differences in the tendencies of sound castings, made from different lots of iron or made from the same iron under different conditions, to give blisters when enameled under identical conditions. The gases forming the blisters are $\mathrm{CO}$ and $\mathrm{CO}_{2}$.

2. A gray iron casting of the composition normally used for enameling acquires in freezing and cooling in the mold a very thin surface skin, which may be considered as a "microchill." This layer extends only a few thousandths of an inch below the surface and varies in thickness, hardness, and resistance to abrasion by the sand blast. Removal of this surface layer eliminates blistering except such as is caused by sponginess or other physical defects which extend more deeply into the interior. The analyses of the surface layers indicate that the hardness and resistance to abrasion may be due either to the higher combined carbon or to some other hard component. 
3. The cementite (combined carbon) of this skin tends to break down, during the enameling process, to very finely divided "temper carbon." This form of finely divided carbon is more readily oxidized, as would be expected from its fineness, than massive graphite or combined carbon.

4. This breakdown to a readily oxidizable form of carbon, analagous to the early stages of the malleableizing of white iron, leads to the formation and evolution of $\mathrm{CO}$ and $\mathrm{CO}_{2}$, upon heating, which causes greater or less damage, according to the stage of the enameling process at which it occurs. If the enamel coat is sufficiently fused to form the gas into bubbles, but not fluid enough to heal after any bubbles of gas have escaped, blisters will occur. If the craters partially heal, there will be dimples. If the enamel is a low melting one, applied at a low temperature, the annealing action coincident with enameling may not be sufficient to produce a breakdown of the cementite accompanied by the formation of the finely dispersed temper carbon, or, if it is produced and $\mathrm{CO}$ and $\mathrm{CO}_{2}$ are formed, the enamel may be fluid enough to allow the gas to escape without damage.

5. There are probably two kinds of nonblistering iron, one in which a small amount of combined carbon is present in the surface layer, and the other in which cementite is so stable that it takes a relatively long time to break it down into ferrite and temper carbon.

6. Decarburization of the skin, as well as its removal by mechanical or chemical means, will eliminate the source of temper carbon. Hence, blister-free ware can be obtained with a sound casting if the enameling process itself is properly carried out, unless the whole casting is of such a nature that the body as well as the skin will give temper carbon on enameling. Some irons have a greater tendency to give the microchilled layer than others. The gas evolution which apparently takes place during the first part of the firing treatment, even from those specimens having the least blistering tendency of any studied, has been assumed to be due mainly to submicroscopic graphite, which burns out too quickly to cause blisters.

7. Aside from such variations as may be attributed to differences in enameling procedure at the different plants, the presence of a hard surface layer or "microchill" probably accounts for most of the inconsistencies observed in the early part of the investigation, as well as those between the results of various laboratories. Unless sandblasting was uniformly controlled and the surface layer uniformly attacked, it is obvious that erratic results would be obtained on enameling.

8. Attempts to nullify the hardening effect of sulphur by addition of manganese do not appear to offer much hope, since excess manganese is in itself harmful. Addition of some graphitizing agents, such as silicon, or any precaution in casting that will tend to minimize the tendency to chill, may be beneficial, but it is much more difficult to prevent the formation of the microchill than the formation of the well understood ordinary or macrochill.

9. In cases when an occasional heat or lot of sound castings show a tendency to blister, "burning out," or deep sand-blasting, appears to be the most practical remedy. 


\section{ACKNOWLEDGMENTS}

While this investigation was first undertaken by the bureau in 1922 , in cooperation with the research committee of the enamel division, American Ceramic Society, under its chairman at that time, R. R. Danielson, the present enlarged cooperative plan of work which this report covers was instituted in 1924 jointly by the ceramics and metallurgy divisions of the bureau and the enamel division research committee, under the chairmanship of H. F. Staley, with some 36 enameling and other interested companies cooperating through the committee. More recently R. R. Danielson has again served as chairman of the enamel division research committee, to the many members of which grateful acknowledgment is made for their assistance in planning and furthering the work.

H. G. Wolfram was in charge of the bureau enamel section's participation during about two years of the investigative work under the cooperative plan. L. D. Jones, of the foundry section, has done highly creditable work in the preparation of specimens. The aid of the late G. T. Thaler, of the enamel section, was of great value because of his constructive suggestions as well as enameling of specimens.

The analytical work on gases and gas-forming elements was carried out by R. J. Kranauer and J. S. Acken, of the metallurgical division of the bureau. All other chemical analyses were made by H. A. Bright and assistants under the supervision of G. E. F. Lundell, of the chemistry division. The spectroscopic analyses were made by W. F. Meggers, of the optics division.

Grateful acknowledgment is made to L. Jordan for aid and counsel, and especially to H. W. Gillett and C. M. Saeger, jr., of this bureau, for their help and guidance throughout the investigation.

\section{SELECTED BIBLIOGRAPHY}

1. Enameling Defects Due to the Cast Iron, A. Malinovsky, J. Am. Ceram. Soc., 8, p. 72; 1925.

2. Note on Vitreous Enameling of Cast Iron, Anonymous, Foundry Trade J., 39, p. 379; 1928.

3. Materials and Methods Used in the Manufacture of Enameled Cast-Iron Wares, H. F. Staley, B. S. Tech. Paper No. 142; 1919.

4. Wet-Process Enamels for Cast Iron, R. R. Danielson and H. P. Reinecker, B. S. Tech. Paper No. 246; 1923.

5. The Wet-Process of Vitreous Porcelain Enameling, W. Marshall, Foundry Trade J., pp. 124, 216; 1927; pp. 66, 134; 1928.

6. Some Effects of Varying Soda and Boric Oxides in Ground-Coat Enamels, R. R. Fusselbaugh, J. Am. Ceram. Soc., 10, p. 270; 1927.

7. Progress Report on Cast Iron for Enameling Purposes, W. N. Harrison, C. M. Saeger, jr., and A. I. Krynitsky, J. Am. Ceram. Soc., 11, p. 595; 1928 .

8. The Protective Value of Nickel Plating, C. T. Thomas and W. Blum, Trans. Am. Electrochem. Soc., 48, p. 76; 1925.

9. A Theory of the Cause of Blisters on Galvanized Sheets, L. B. Lindemuth, Min. \& Met., 8, p. 225; 1927.

10. Surface Hardening of Special Steels with Ammonia Gas Under Pressure, R. H. Hobrock, Trans. Am. Soc. Steel Treat., 14, p. 337; 1928; Table 3.

11. Steels for Case Nitrification, A. B. Kinzel, Trans. Am. Soc. Steel Treat., 14, p. 248; 1928. Discussion, P. C. Osterman, p. 253 . Some Practical Aspects of the Nitriding Process, H. W. McQuaid and W. J. Ketchen, Trans. Am. Soc. Steel Treat., 14, p. 719; 1928. Methods of Approximating Certain Physical Characteristics of Nitrided Steel Cases, G. M. Eaton, Trans. Am. Soc. Steel Treat., 15, p. 1; 1929. Nitrogen in Steel and the Erosion of Guns, H. E. Wheeler, Trans. Am. Inst. Min. \& Met. Eng., 4\%, p. $270 ; 1922$. 
12. Effect of Various Elements on Malleable Cast Iron, L. E. Gilmore, Trans. Am. Foundrymen's Assn., 36, p. 291; 1928.

13. Nickel and Nickel Chromium Cast Iron, T. H. Wickenden and J. S. Vanick, Trans. Am. Foundrymen's Assn., 33, p. 346; 1925. The Effects of Chromium and Nickel in Cast Iron, R. S. Porster, Trans. Am. Foundrymen's Assn., 35, p. 356; 1927. The Influence of Nickel on Combined Carbon in Gray Iron, J. R. Houston, Trans. Am. Soc. Steel Treat., 15, p. 145; 1929.

14. Chemical Elements Inhibiting Graphitization, H. A. Schwartz and G. M. Guiler, Trans. Am. Foundrymen's Assn., 33, p. 639; 1925. See also Discussion, H. A. Schwartz, Trans. Am. Soc. Steel Treat. 11, p. 708; 1927.

15. The Cause of Variations in Pig Iron Qualities, R. S. McCaffery, Trans. Am. Foundrymen's Assn., 3ือ, p. 427; 1927.

16. An Investigation of Liquid Contraction in Cast Iron, Pt. 2, G. Hailstone, Iron and Steel Inst.; Carnegie Scholarship Mem., p. 55; 1916.

17. Carbon in Cast Iron, P. Ropsy, The Foundry Trade J., 36, p. 199; 1927. Some Graphite Formations in Gray Cast Iron, T. W. Bolton, Trans. Am. Foundrymen's Assn., 35, p. 386; 1927.

18. Discussion, W. R. Bean, Trans. Am. Foundrymen's Assn., 36, p. 824; 1928.

19. Theory and Practice in the Gray Iron Foundry, J. Shaw, Trans. Am. Foundrymen's Assn., 36, p. 293; 1928. Influence of Elements on Cast-Iron Structure, J. Shaw, Foundry, 54, pp. 767, 771, 825; 1926.

20. Progress in the Production of High-Test Cast Irons, E. Piwowarsky, Trans. Am. Foundrymen's Assn., 34, p. 914; 1926.

21. How Phosphorus Influences Carbon in Cast Iron, J. T. McKenzie, Foundry, p. $281 ; 1926$.

22. Discussion, W. B. Parker, Trans. Am. Foundrymen's Assn., 36, p. 849; 1928.

23. On the Causes of Variations in the Rate of Graphitization of White Cast Iron, A. Hayes and H. E. Flanders, Trans. Am. Foundrymen's Assn., 33, p. $634 ; 1925$.

24. Notes on the Graphitization of White Cast Iron, P. D. Merica and L. J. Gurevich, Bu. S. Tech. Paper No. 129; 1919. Cast Iron in the Light of Recent Research, W. H. Hatfield (Book), 2d ed., p. 91; 1928. Metallography-Metals and Common Alloys, S. L. Hoyt (Book), p. 295. Influence of Manganese on Mechanical Properties of Gray Cast Iron, F. Wüst and H. Meissner, Ferrum, 11, p. 97; 1914.

25. Theoretical Consideration of the Precipitation of Carbon in Black Malleable Castings, M. Guedras, Fonderie Moderne, 20, pp. 66, 247; 1926.

26. The Reaction Between Ferrous Oxide and Carbon and Between Carbon Dioxide and Iron, V. Falcke, Zeit. für Electrochem., 21, p. 37; 1915. See also Equilibria in the Systems Iron; Carbon: Oxygen and Iron: Hydrogen and the Free Energies of the Oxides of Iron, E. D. Eastman, J. Am. Chem. Soc., 49, p. 975; 1922.

27. Oxidation During Annealing of Malleable Cast Iron, H. A. Schwartz, Trans. Am. Foundrymen's Assn., 36, p. 385; 1928.

28. The Catalysis of the Graphitization of White Cast Iron by the Use of $\mathrm{CO}-\mathrm{CO}_{2}$ Mixtures When Applied Under Pressure, A. Hayes and H. E. Flanders, Trans. Am. Foundrymen's Assn., 33, p. 575; 1925.

29. Study of Unreduced Oxides in Pig Iron, C. H. Herty, jr., and J. M. Gaines, jr., Am. Inst. Min. \& Met. Eng. Tech. Pub. No. 165; Blast Furnace \& Steel Plant, 1\%, 3, p. 418; 1929.

30. "Das Emallierfähige Gusseisen," A. Müller, Giesserei Zeitung, 6, pp. 247250; 1929. Abstract Iron \& Steel Ind., p. 290; June, 1929.

Wasmington, September 13, 1929. 